\title{
Central African Republic: Poverty Reduction Strategy Paper- First Annual Progress Report
}

Poverty Reduction Strategy Papers (PRSPs) are prepared by member countries in broad consultation with stakeholders and development partners, including the staffs of the World Bank and the IMF. Updated every three years with annual progress reports, they describe the country's macroeconomic, structural, and social policies in support of growth and poverty reduction, as well as associated external financing needs and major sources of financing. This country document for Central African Republic, dated March 2009, is being made available on the IMF website by agreement with the member country as a service to users of the IMF website.

Copies of this report are available to the public from

International Monetary Fund • Publication Services

$70019^{\text {th }}$ Street, N.W. • Washington, D.C. 20431

Telephone: (202) 623-7430 • Telefax: (202) 623-7201

E-mail: publications@imf.org • Internet: http://www.imf.org

\section{International Monetary Fund Washington, D.C.}



Central African Republic

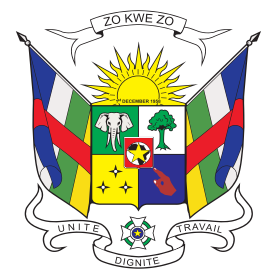

POVERTY REDUCTION STRATEGY PAPER (PRSP) 2008-2010

REPORT ON FIRST YEAR OF IMPLEMENTATION

March 2009 


\section{List of abbreviations and acronyms}

\begin{tabular}{|c|c|}
\hline ACDA & $\begin{array}{l}\text { Agence Centrafricaine du Développement Agricole [Central African Agency for } \\
\text { Agricultural Development] }\end{array}$ \\
\hline ACFPE & $\begin{array}{l}\text { Agence Centrafricaine pour la Formation Professionnelle et l'Emploi [Central } \\
\text { African Agency for Vocational Training and Employment] }\end{array}$ \\
\hline AFD & French Development Agency \\
\hline AfDB & African Development Bank \\
\hline AFRISTAT & Economic and Statistical Observatory of Sub-Saharan Africa \\
\hline AIDS & Acquired Immuno-Deficiency Syndrome \\
\hline ALPC & Armes Légères et de Petit Calibre [Light and Small Caliber Weapons] \\
\hline APE & Association des Parents d'Elèves [Association of Parents of Students] \\
\hline ARCAD & $\begin{array}{l}\text { Appui au Renforcement des Capacités pour la mise en œuvre du DSRP [Capacity- } \\
\text { Building Assistance with respect to PRSP Implementation] }\end{array}$ \\
\hline ARV & Anti Retro Viral \\
\hline ASECNA & $\begin{array}{l}\text { Agence pour la Sécurité de la Navigation Aérienne en Afrique et Madagascar } \\
\text { [Agency for the Security of Air Navigation in Africa and Madagascar] }\end{array}$ \\
\hline BADEA & Arab Bank for Economic Development in Africa \\
\hline BDEAC & Central African States Development Bank \\
\hline BEAC & Bank of Central African States \\
\hline BEC & Bureau d'Évaluation et de Coordination [Assessment and Coordination Office] \\
\hline BONUCA & U.N. Bureau in Central African Republic \\
\hline CAR & Central African Republic \\
\hline $\mathrm{CAS} / \mathrm{DFT}$ & $\begin{array}{l}\text { Compte d'Affectation Spéciale de Développement Forestier et Touristique [Special } \\
\text { Earmarked Account for Forestry and Tourism Development] }\end{array}$ \\
\hline $\mathrm{CBO}$ & Community-Based Organization \\
\hline CCIMA & $\begin{array}{l}\text { Chambre de Commerce, d'Industries, des Mines et de l'Artisanat [Chamber of } \\
\text { Commerce, Industries, Mines, and Crafts] }\end{array}$ \\
\hline CEMAC & Economic and Monetary Community of Central African States \\
\hline CIMIC & Civic Military Cooperation \\
\hline CNLS & Comité National de Lutte contre le Sida [National Committee against AIDS] \\
\hline CNPT & Comité National Permanent de Travail [Standing National Committee on Work] \\
\hline CNS & Comité National Stratégique [Strategic National Committee] \\
\hline CNT & Comité National Technique [National Technical Committee] \\
\hline CNTS & Centre National de Transfusion Sanguine [National Blood Transfusion Center] \\
\hline COGES & Comité de Gestion [Management Committee] \\
\hline COOPI & Italian Cooperative \\
\hline CPR & Centre Pédagogique Régional [Regional Educational Center] \\
\hline CRESMIC & $\begin{array}{l}\text { Cadre de Référence et Support Méthodologique Minimum Commun pour la } \\
\text { conception d'un système d'Informations pour le suivi des DSRP et des OMDs } \\
\text { [Frame of Reference and Common Core Methodological Support for Designing an } \\
\text { Information System for Tracking the PRSPs and the MDGs] }\end{array}$ \\
\hline CTP-PAS & $\begin{array}{l}\text { Comité Technique Permanent de suivi des Programmes d'Ajustement Structurel } \\
\text { [Standing Technical Committee for Monitoring Structural Adjustment Programmes] }\end{array}$ \\
\hline
\end{tabular}




\begin{tabular}{|c|c|}
\hline DAD & Development Assistance Database \\
\hline DCP & Document Cadre de Partenariat [Framework Document on Partnership] \\
\hline DEA & Diplôme d’Etudes Approfondies [Advanced Degree] \\
\hline DEC & Delegation of the European Commission \\
\hline DPI & Dialogue Politique Inclusif [Inclusive Political Dialogue] \\
\hline EDF & European Development Fund \\
\hline EITI & Extractive Industries Transparency Initiative \\
\hline ENAM & $\begin{array}{l}\text { Ecole Nationale d'Administration et de Magistrature [National School of } \\
\text { Administration and the Courts] }\end{array}$ \\
\hline ENI & Ecole Normale d'Instituteur [Teacher Training College] \\
\hline EPA & Etablissement Public Administratif [Administrative Public Entity] \\
\hline EU & European Union \\
\hline FAO & Food and Agriculture Organization \\
\hline FDS & Forces de Défense et de Sécurité [Defense and Security Forces] \\
\hline FER & Fonds d'Entretien Routier [Road and Highway Maintenance Fund] \\
\hline FOSA & Formation Sanitaire [Public Health Unit] \\
\hline GAVI & Global Alliance for Vaccines and Immunization \\
\hline GDP & Gross Domestic Product \\
\hline HIPC & Heavily Indebted Poor Country \\
\hline ICASEES & $\begin{array}{l}\text { Institut Centrafricain des Statistiques et des Etudes Economiques et Sociales [Central } \\
\text { African Institute for Economic and Social Studies and Statistics] }\end{array}$ \\
\hline ICRA & $\begin{array}{l}\text { Institut Centrafricain de Recherches Agronomiques [Central African Institute for } \\
\text { Agronomic Research] }\end{array}$ \\
\hline IFAD & International Fund for Agricultural Development \\
\hline IIMM & Insecticide Impregnated Mosquito Net \\
\hline IMCI & Integrated Management of Childhood Illness \\
\hline JPN & Jeunesse Pionnière Nationale \\
\hline LAC & Less Advanced Country \\
\hline LIW & Labor-Intensive Work \\
\hline MDGs & Millennium Development Goals \\
\hline MICS & Multiple Indicators Cluster Survey \\
\hline MINURCAT & United Nations Mission in the Central African Republic and Chad \\
\hline MNNH & Maternal-Neonatal Health \\
\hline MNT & Maternal-Neonatal Tetanus \\
\hline MPECI & Ministry of Planning, Economy and International Cooperation \\
\hline MTEF & Medium-Term Expenditure Framework \\
\hline NGO & Non-Governmental Organization \\
\hline ODA & Official Development Assistance \\
\hline OEV & Vulnerable Orphans and Children \\
\hline OMS & World Health Organization \\
\hline PIR & Programme Indicatif Régional [Regional Indicative Program] \\
\hline PLHIV & Persons Living with HIV \\
\hline PPBMS & Planning, Programming, Budgeting, and Monitoring System \\
\hline PRAC & $\begin{array}{l}\text { Projet de Réinsertion des ex-combattants et d'Appui aux Communautés [Project for } \\
\text { the Reintegration of Ex-Combattants and Support for Communities] }\end{array}$ \\
\hline
\end{tabular}




$\begin{array}{ll}\text { PRGF } & \text { Poverty Reduction and Growth Facility } \\ \text { PRSP } & \text { Poverty Reduction Strategy Paper } \\ \text { PSES } & \text { Projet Santé Education et SIDA [Health, Education, and AIDS project] } \\ \text { TFP } & \text { Technical and Financial Partner } \\ \text { QUIBB } & \text { Unified Questionnaire on Basic Welfare Indicators } \\ & \\ \text { REP } & \text { Regional Economic Program } \\ \text { ROM } & \text { Results Oriented Management } \\ \text { RSS } & \text { Réforme du Secteur de la Sécurité [Security Sector Reform] } \\ \text { SNDS } & \text { Stratégie National de Développement de la Statistique [National Strategy for the } \\ & \text { Development of Statistics] } \\ \text { SSN } & \text { Système Statistique National [National Statistical System] } \\ \text { SSV } & \text { Suivi des Services de Vaccination [Tracking of Vaccination Services] } \\ \text { STN } & \text { Secrétariat Technique National [National Technical Secretariat] } \\ \text { STP } & \text { Secrétariat Technique Permanent [Permanent Technical Secretariat] } \\ \text { SYDONIA } & \text { ASYCUDA } \\ \text { SYSGAD } & \text { Automated Debt Management System } \\ \text { UCM } & \text { Unité de Cession du Médicament [Medication Delivery Unit] } \\ \text { UFDR } & \text { Union des Forces Démocratiques pour le Rassemblement } \\ \text { UFVN } & \text { Union des Forces Vives de la Nation } \\ \text { UNDP } & \text { United Nations Development Programme } \\ \text { UNFPA } & \text { United Nations Fund for Population Activities } \\ \text { UNICEF } & \text { United Nations Fund for Children } \\ \text { UNS } & \text { United Nations System } \\ \text { USA } & \text { United States of America } \\ \text { US\$ } & \text { United States Dollar (US\$= CFAF 500) } \\ \text { WCBA } & \text { Women of Childbearing Age } \\ \text { WFP } & \text { World Food Programme } \\ & \end{array}$


Contents

Page

LIST OF ABBREVIATIONS AND ACRONYMS ............................................................ 2

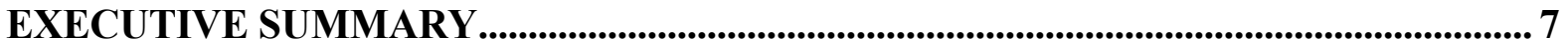

INTRODUCTION

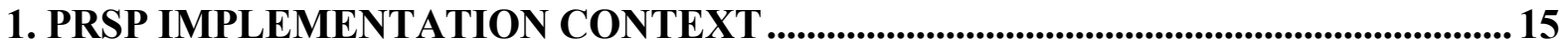

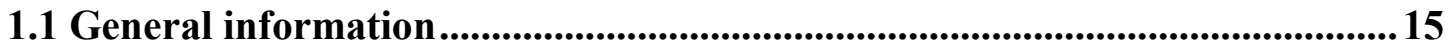

1.2 Social and economic characteristics .............................................................. 15

1.3 Review of the conclusions of the Brussels Round Table .................................. 16

1.4 Review of the midterm conclusions .............................................................. 17

1.4.1 Key government achievements .................................................... 17

1.4.2 Key commitments of the development partners ............................... 17

1.5 Conclusions of the annual review..................................................................... 17

2. EVALUATION/TRACKING AND INSTITUTIONAL MECHANISM...................... 19

2.1 Institutional mechanism................................................................................................ 19

2.2 Evaluation/tracking tools and statistical apparatus......................................... 19

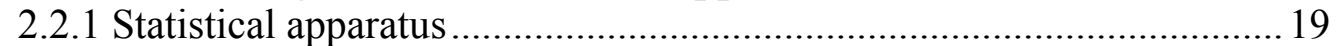

2.2.2 Evaluation/tracking tools............................................................. 21

2.3 The participatory tracking mechanism and active communications .............. 21

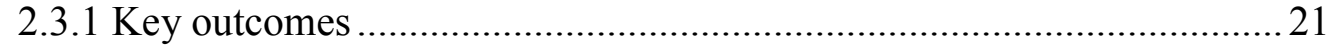

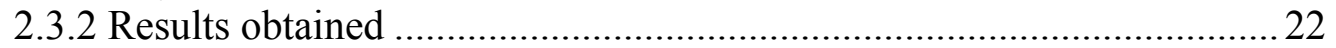

2.4 Capacity-building ................................................................................................... 23

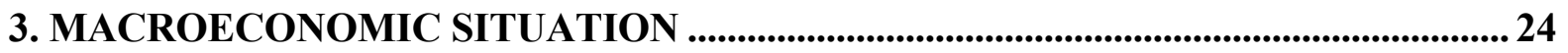

3.1 Macroeconomic trends ....................................................................................24

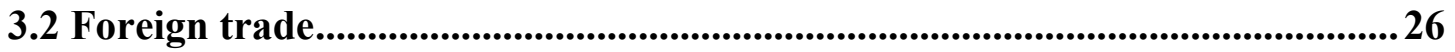

3.3 Monetary situation ............................................................................................... 26

3.4 Fiscal position ........................................................................................................ 26

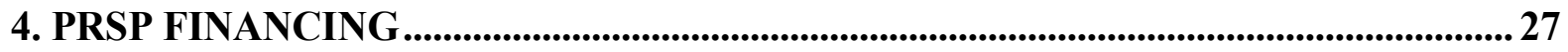

4.1 Mobilization of domestic resources........................................................................ 27

4.2 Structure of public expenditure ................................................................................... 28

4.3 Mobilization of external financing .........................................................................2 29

4.4 Status of commitments, payments, and expenditures in 2008......................... 31

5. ASSESSMENT OF PRSP IMPLEMENTATION .............................................................. 35

5.1. Restore security, consolidate peace, and prevent conflict ............................35

5.1.1. Strengthening the human and material capacities of the FDS

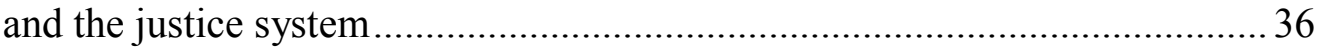

5.1.2. Reform, restructuring, territorial reorganization and coordinated, participatory transformation of the FDS ................................................ 37

5.1.3. Sub-regional security, and efforts to contain the proliferation

of small arms and light weapons 
5.1.4. Education, development and restoring trust in the FDS.........................38

5.2. Promote good governance and the rule of law.....................................................4 40

5.2.1. Promotion of good governance ……………...................................... 41

5.2.2. Create a favorable business environment............................................. 44

5.2.3. Promoting gender equality and equity................................................... 45

5.3. Rebuilding and diversifying the economy .............................................................46

5.3.1. Modernizing agriculture and livestock raising ...................................... 47

5.3.2. Making better use of forest resources................................................. 48

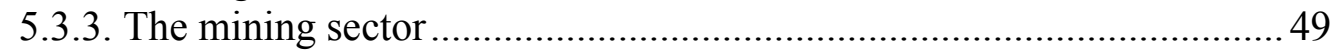

5.3.4. Promoting the arts and cultural heritage................................................5 50

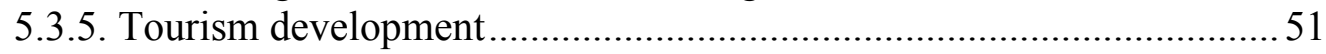

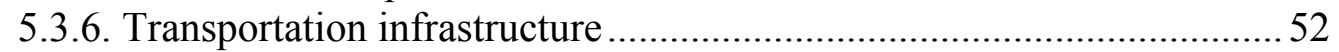

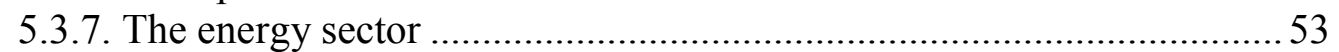

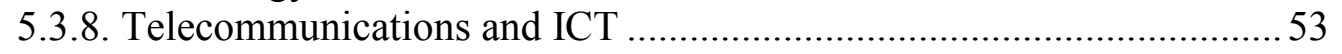

5.4. Developing human capital ..........................................................................................55

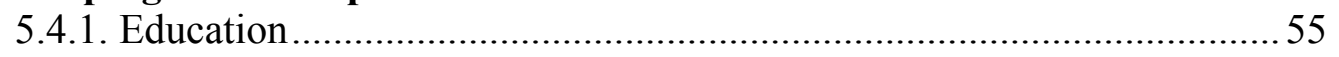

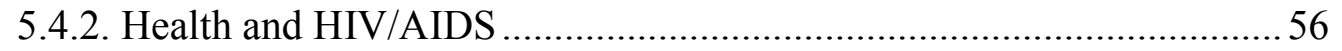

5.4.3. Youth and sport .............................................................................. 58

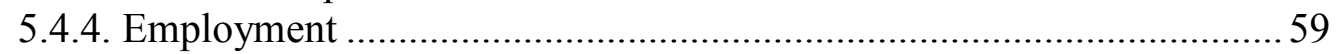

5.5. Poverty assessment indicators ................................................................................60

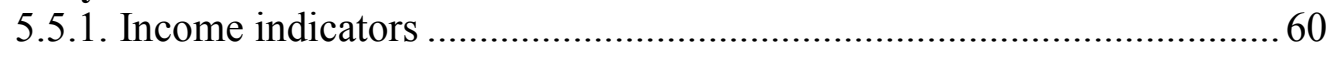

5.5.2. Standard-of-living indicators.................................................................. 61

6. CONSTRAINTS AND OUTLOOK .......................................................................................62 62

6.1 Main constraints and threats.................................................................................62

6.2 Outlook and main opportunities ..................................................................................6 64

CONCLUSION ................................................................................................................................................ 67

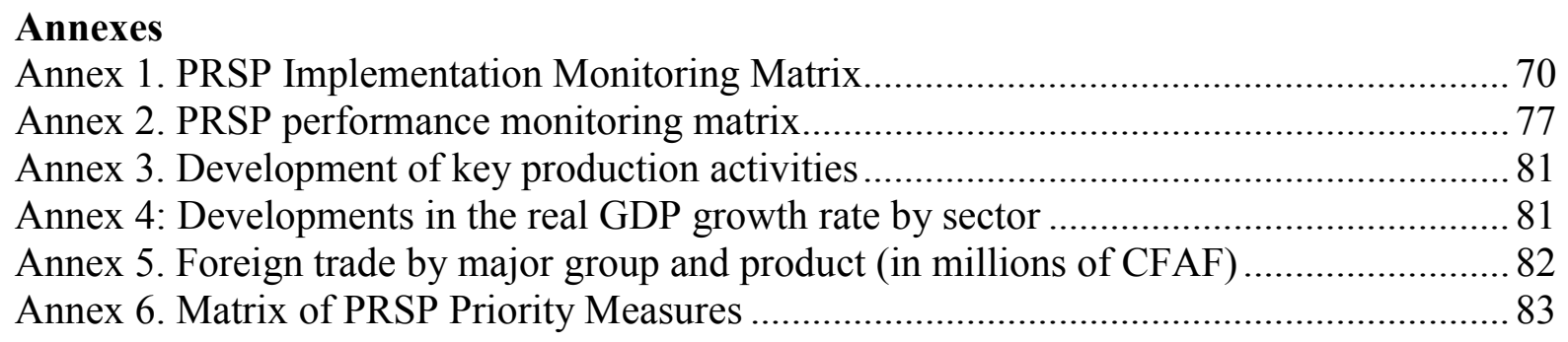




\section{Executive summary}

\section{PRSP implementation context}

The Central African Republic (C.A.R.) is a landlocked country in Central Africa that was profoundly affected by political and military crises during the period 1996-2003, leading to a serious deterioration in its economic fabric.

An economic recovery began in 2006 with the support of the international community, but it remains slow. The reforms undertaken by the government and satisfactory implementation of successive adjustment programs have enabled the C.A.R. to begin fiscal consolidation efforts, have led to a recovery of investment in the secondary and tertiary sectors and an upturn in consumption, and have allowed the government to make poverty reduction a priority in all policies. The PRSP was adopted against this backdrop during a national seminar in September 2007 and the HIPC Initiative decision point was reached that same month.

To seek support for its post-conflict recovery efforts, the government organized a Round Table Conference in Brussels on October 26, 2007 to mobilize its key partners around its PRSP objectives.

It was followed by a two-stage assessment of the commitments made:

(i) a June 2008 midterm review took stock of PRSP outcomes since October 2007 and led to the adoption of a roadmap laying out the main stages for implementing the priority PRSP actions in 2008. This review revealed that 14 percent of the financing announced in Brussels had been obtained; and

(ii) a November 2008 annual review, which indicated that 80 percent of commitments had been mobilized.

\section{Evaluation/tracking and implementation mechanism}

Effective implementation of the PRSP programs and projects is managed using an institutional framework that is currently being put into operation, a statistical apparatus, and a participatory mechanism.

Five bodies make up the institutional framework:

- The National Strategic Committee (CNS) is responsible for establishing the key PRSP implementation thrusts and is chaired by the Prime Minister. The U.N. Resident coordinator is the vice chair.

- The National Technical Committee (CMT) is responsible for maintaining a permanent dialogue between the government and each development partner and is chaired by the Minister of State for Planning, Economy, and International Cooperation;

- The National Technical Secretariat (STN) is responsible for technical coordination of PRSP evaluation/tracking and implementation and is headed by an Expert Coordinator;

- The Sectoral Committees (CS) are responsible for developing and implementing sectoral strategies and are chaired by ministerial department heads, who are supported by lead managers from the development partners intervening in the sector;

- The Regional Committees (CR) are responsible for participatory evaluation/tracking of the PRSP and regional projects and are chaired by préfets. A representative of civil society is the vice chair.

The statistical apparatus for tracking the PRSP is based on AFRISTAT's Reference Framework and Common Minimum Methodological Guidelines with three subsystems: (i) the household living conditions tracking subsystem; (ii) the program and project tracking subsystem; and (iii) the program and policy impact assessment subsystem. These subsystems complement each other and are an integral part of the results-based management approach. 
The main PRSP evaluation/tracking tools are the reporting system, the performance indicators, the DevInfo database, and the aid management and tracking system.

Participatory tracking provides ownership of the PRSP by communities, making them aware of their role in ensuring effective participation and involvement in the selection of policies and programs, priorities, and resources. Communication has been identified as a key tool for creating discussion and dialogue for sharing knowledge, expertise, and experience.

The constraints affecting the proper functioning of the various components of the mechanism are the result mainly of capacity weaknesses, while the current capacity-building strategy has not yet fully achieved its results.

\section{Macroeconomic situation}

In 2008, the C.A.R. economy was affected by the serious shocks at the international level: oil price fluctuations, the international financial crisis, the instability of prices for its main export products, and the world food crisis, which resulted in a build-up of inflationary pressures. At the national level the persistence of the energy crisis and the slowdown in economic growth resulted in a growth rate of 2.8 percent, compared with 4.3 percent in 2007.

Prices rose in 2008, and the inflation rate was estimated at 9.3 percent, compared with 1 percent in 2007. The resultant inflationary pressures were eased by government measures to lower taxes on certain staples.

The foreign trade deficit increased 102.6 percent from 2007 to 2008.

The C.A.R. monetary situation in December 2008 was characterized by a 26.5 percent decline in net foreign assets from December 2007. For the period under review, credit to the economy increased by some 10.3 percent

Primary expenditure increased by 15.5 percent in 2008 as compared with 2007 , and revenues by 10 percent owing to the improvement in tax revenues.

The gradual restoration of external solvency continued with the clearance of arrears and a three-year grace period for Paris club bilateral debt. Outstanding debt rose 0.7 percent from 2007 to 2008 while debt service declined 23.9 percent in the same period.

\section{PRSP financing}

PRSP financing needs are assessed at CFAF 633 billion in September 2007, or US\$1.3 billion, of which 66 percent has been allocated to Pillar III, which focuses on economic recovery and diversification, and 23 percent to Pillar IV, which relates to development of human capital.

Under the terms of the Brussels Round Table Conference, announced financing covers close to 40 percent of expressed needs, leaving a financing gap of 60 percent. Analysis of the financing gap shows that it is largest in Pillar III (55 percent). As of November 15, 2008, US\$840 million had been mobilized under financing agreements signed in the context of cooperation programs ranging from 3 to 6 years.

To increase the share of domestic PRSP financing, the government has undertaken to improve its fiscal management and streamline budgetary allocations by nature and by sector. These commitments have led to: 
- the introduction of tax and customs measures;

- effective implementation of the recommendations of the audit reports on the one-stop shop in Douala;

- reform of the Public Treasury; and

- increase in the share of the social sectors in the overall budget.

In addition, tax revenues and investment expenditures included in the government budget in 2007 and 2008 rose 21.3 percent and 21.6 percent, respectively.

Tracking the budgetary allocations for the priority sectors over the medium term will be facilitated by the introduction of a Medium-Term Expenditure Framework (MTEF), creating a link between the PRSP programs and the budget. An appropriate mechanism has been put in place for this purpose.

\section{Status of PRSP implementation}

\subsection{Restoration of security, consolidation of peace, and conflict prevention}

The major actions undertaken by the government in this sector arise from the Security Sector Reform (SSR) and relate to:

Central African Armed Forces (FACA) and the Gendarmerie

- personnel who have reached the age limit have been retired; the agreement with the donor to support the government in the payment of wage arrears has been finalized;

- recruitment by competition at the national level; results are monitored by the local authorities and an external observer;

- a committee to review and update laws and regulations has been created and is operational;

- the multiyear sectoral estimates law (loi de programmation) is being finalized;

- 960 members of the Defense and Security Forces (DFS) have been trained;

- 12 public awareness campaigns have been organized;

- "open doors" days have been organized;

- 25 illegal barriers have been dismantled.

National Police

- the special status of the police has been enacted (Law 08.016 of May 20, 2008);

- public awareness campaigns have been organized for the judicial, administrative, and political authorities;

- 300 uniforms have been provided for the police by the French technical assistance authorities.

Justice

- 4 managers and 12 female prison guards have been trained;

- the Legal Security Support Project (PRASEJ) is being implemented.

Water and forests

- the Forestry Code has been enacted (Law 08.022 of October 17, 2008);

- social mediators in the PEA management units under management agreements are making waterfront populations aware of the distribution of forestry taxes paid to the communes by the committee responsible for validation of the employment program and also host public awareness 
broadcasts on local rural radio. At the department level this campaign is taken up by the communications and extension unit, which hosts a radio and television broadcast, and by the Ministry of Water, Forestry, Hunting, Fishing, and the Environment, which has a column entitled "PENDERE GBAKO" in the print media. An economic observatory has just been created for this purpose, grouping various ministerial departments (Ministry of Planning, Ministry of Finance, and the CTP/PAS). The partners have recommended that information on resources flowing to the communities be posted in the communes.

These efforts led to the inclusion of the Central African Republic on the agenda of the United Nations Peacebuilding Commission (PBC) in June 2008.

The main recommendations from the Inclusive Political Dialogue held in Bangui from December 8 to 20, 2008 have begun to be implemented with the: (i) establishment of the broad consensus government, (ii) introduction of the committee monitoring the recommendations of the Dialogue, and (iii) start up of the Disarmament, Demobilization and Reintegration (DDR) process with the census of ex-combatants.

\subsection{Promoting good governance and the rule of law}

To promote a culture of democracy, respect of human rights, effective government, and effective fiscal management, continued efforts in these areas have led to the following results:

Promoting a culture of democracy:

- an information sciences department has been created at the University of Bangui;

- a social dialogue has been initiated with the unions;

- the Inclusive Political Dialogue has been organized.

Promoting respect of human rights:

- 10 managers of units in the Office of the High Commissioner for Human Rights have been trained;

- the draft Criminal Code, Code of Criminal Procedure, and Military Justice Code are under revision;

- the Central African Republic is in the process of joining the global information network.

Enhancing the effectiveness of the government:

- the simplified government hiring procedure is being applied;

- audits of the seven pilot ministries are being organized.

Fiscal consolidation:

- the SYSGAD software has been installed in the Debt Directorate;

- a computer system has been installed in the General Directorate of the Budget and Treasury;

- a liquidity monitoring committee has been created;

- the law on the procurement code has been adopted;

- the procurement regulatory authority has been created.

Promotion of gender equality and equity by means of a national legal instrument promoting equal opportunities was continued with the organization of: (i) two training sessions on gender, reproductive health, HIV, and tracking/evaluation in June and July 2008, (ii) a training session on data collection in November 2008, (iii) three public awareness sessions on two laws on reproductive health and the protection of women against violence in September 2008.

\subsection{Rebuilding and diversifying the economy}


As part of the recovery and diversification of the economy, the government has focused its attention on agriculture and livestock, mining, forestry, tourism, energy, infrastructure, trade and the private sector, water and sanitation, and housing.

In the mining sector, an audit was carried out for purposes of revising the Mining Code and a decree created an institutional framework for the Extractive Industries Transparency Initiative (EITI). Work was begun in the technical unit established for that purpose toward the adoption of the standard agreement and its alignment with the Mining Code.

In the forestry sector, an interministerial technical committee including representatives of local communities was created to manage forestry and hunting taxes, the proceeds of which will be deposited in an account opened with the Bank for Central African States (BEAC). In addition, a new Forestry Code was enacted on October 17, 2008 and an economic observatory was created.

In the tourism sector, 50 staff members of hotels and restaurants were trained in reception and culinary arts techniques and 20 were trained in taxidermy.

In the energy sector, a law creating the Agency for the Stabilization and Regulation of Oil Prices was adopted and implemented.

In the area of infrastructure, activities focused on the rehabilitation of five roads totaling $1177 \mathrm{~km}$, and the construction and rehabilitation of three bus terminals.

In the area of trade, the creation of the one-stop shop for the formalities of setting up a company (GUFE) is a significant step toward promoting the private sector by significantly reducing the time required to create a production unit, as are the establishment of the Project Management Unit and the startup of the Integrated Framework.

Two agencies have been created in the water and sanitation sector: the Water and Sanitation Sector Regulation Agency and the National Water and Sanitation Agency. The activities of these agencies have helped improve the living conditions of beneficiaries and strengthened the capacities of the participants.

In the housing sector, the blueprint for the city of Bangui has been prepared.

\subsection{Developing human capital}

To tackle supply problems in the education sector, activities have focused on the rehabilitation/construction and equipment of schools.

Measures have also been taken to improve the quality of teaching: reading (4625) and mathematics textbooks (4625) have been purchased, 850 contract teachers have been recruited at the primary level, and the pupil/ teacher ratio was reduced from 96 to 82 between 2007 in 2008.

To strengthen the partnership among the various participants in the educational system, 300 members of parent teacher associations in target zones were given awareness training on education for children, particularly girls.

In the health sector, activities have focused on the rehabilitation/construction and equipment of infrastructure in the health regions. For infant and maternal health, a plan to extend Integrated Care for 
Childhood Diseases (PCIME) was prepared for the period 2007-2011 and a new policy introduced five-inone vaccines in September 2008.

A tracking/evaluation plan for the national strategic framework for combating HIV/AIDS was prepared in March 2008. More than 89 percent of condoms that were to be distributed were actually distributed in 2008, and 13 new management units were created.

In the areas of employment, vocational training, and entrepreneurship, a technical committee that will be broadened to include other ministries is being created to prepare for the national forum that will be tasked with preparing a national policy on employment and vocational training. The new draft Labor Code is being studied by the National Assembly. Sixty young people benefited from apprenticeship training with artisans, and 12 young people received assistance from the support fund for revenue-generating activities.

In the area of youth and sports, one youth and culture center has been rehabilitated and another has been constructed.

As part of the Microprojects Program (PMR), experts in the guidance of managers of microprojects and Grassroots Community Organizations (GCO) have been trained, and 20 percent of the economic and social microprojects put forward have been carried out.

\section{Constraints and outlook}

Effective implementation of the PRSP is dependent on a series of conditions, including, in particular, the mobilization of resources, the effectiveness of the institutional framework, and the national and international economic context. After one year of PRSP implementation the main constraints and threats have been as follows: (i) mobilization of resources, (ii) weakness of human capacities, (iii) the international economic and financial crisis, and (iv) specific constraints in particular sectors, namely, agriculture, energy, and infrastructure, which are not yet fully playing their role.

Despite these constraints and threats, the medium-term exercise is being carried out against a backdrop of opportunities that must be seized to ensure that poverty trends are reversed: (i) start-up of large projects, (ii) establishment of the development centers, (iii) impact of the HIPC Initiative (reaching of the decision

point and completion point), (iv) more rigorous fiscal management, (v) gradual easing of the political climate, (vi) the Gleneagles scenario of more rapid achievement of the Millennium Development Goals (MDG), and (vii) subregional integration. 


\section{Introduction}

In September 2007, the Central African Republic adopted its first Poverty Reduction Strategy Paper (PRSP) prepared using a participatory approach with the support of its development partners. This approach allowed for a consensus among the various stakeholders in the country and the developer partners, making this document a unique reference framework for government action. The PRSP includes both post-conflict recovery imperatives and measures to achieve the Millennium Development Goals (MDGs). The key objectives remain consolidating peace, creating wealth, and broadening access to basic social services.

The Central African Republic's PRSP was adopted as a reference framework for future intervention by all the development partners during the Round Table Conference organized by the government in Brussels on October 26, 2007. The government received frank backing from the partners, which encouraged it to continue its efforts to implement its economic program supported by the Poverty Reduction and Growth Facility (PRGF). In implementation of the recommendations of this Round Table, in November 2007 the government drew up a list of 155 priority programs and projects to be put forward for donor financing in the context of sectoral consultations that will take place in sectoral round tables.

The PRSP evaluation/tracking and implementation institutional framework was formalized in Prime Ministerial Decree 003 of March 12, 2008. This decree provides a mechanism consisting of five bodies namely: (i) a National Strategic Committee; (ii) a National Technical Committee; (iii) a National Technical Secretariat; (iv) Sectoral Committees; and (v) Regional Committees. The implementation of this mechanism, which is currently under way, will lead to ownership and affirmation of the national leadership, as well as real involvement of all national stakeholders in the PRSP implementation process.

As part of the PRSP implementation mechanism and the actions decided during the Brussels Round Table, a midterm review of the commitments made by the government and the partners was organized on June 26, 2008 in Bangui to measure progress made. At the conclusion of this midterm review, a roadmap was prepared and adopted, setting out the major actions to be taken by the government in 2008. As a direct outcome of the permanent dialogue with the partners and concerted implementation of the PRSP, an annual review of the implementation of the PRSP commitments and actions was also organized on November 20, 2008 in Bangui with a view to: (i) taking stock of progress made in achieving the poverty reduction goals and (ii) proposing any necessary adjustments to improve the results.

This PRSP implementation report has a dual purpose: (i) to take stock of PRSP implementation in 2008 and (ii) identify the constraints and difficulties that hampered action during this period and the outlook for the Central African Republic in pursuing its PRSP implementation in a more satisfactory manner. The participatory process, which is the principle that has prevailed until now, was again implemented in accordance with the tradition of promoting participation and involvement of the various stakeholders.

From a methodological viewpoint, this first PRSP implementation report was prepared in several stages:

- establishment in August 2008 of an interministerial committee in the Ministry of Planning, Economy, and International Cooperation (MPECI) responsible for preparing the annual review. In a series of meetings, this committee prepared a pre-report based on the various implementation reports from the ministerial departments;

- review and expansion of the implementation pre-report in September 2008 by the sectoral and thematic committees in accordance with their mandates;

- submission of the pre-report to the Technical and Financial Partners (TFP), private sector organizations, and civil society for their comments and contributions in October 2008;

- preparation of the draft report in mid-October 2008 by a small team of MPECI experts, which proposed revisions to take account of the comments and amendments received from the TFP and other stakeholders; 
- presentation of the various sectoral reports on November 20, 2008 to the National Strategic Committee followed by finalization of the first draft with the assistance of the World Bank and UNDP;

- release of the report by the Minister of State for Planning, Economy, and International Corporation during the seminar organized on February 11, 2009 as part of the ongoing dialogue with all the stakeholders.

This report focuses on six key points:

- the general context for the exercise, with an overview of the general and socioeconomic characteristics of the Central African Republic, the conclusions of the Brussels Round Table, and the midterm review;

- the institutional mechanism for PRSP implementation, particularly the institutional framework, the statistical apparatus, and aspects related to the participatory approach and capacity-building;

- the current macroeconomic situation, comparing it to the reference framework used for the PRSP;

- PRSP financing, with a focus on resource needs and their mobilization;

- the structure of this report, describing in detail, pillar by pillar, in the form of a status report, the objectives pursued, outcomes, and any results;

- the constraints and outlook for the PRSP evaluation/tracking and implementation exercise, to shed more light on the difficulties encountered so as to identify the adjustments needed to continue the exercise under more favorable conditions.

This report on the first year of PRSP implementation could not take account of all the indicators on which it was supposed to be based owing to: (i) delayed adoption of the list of these indicators, (ii) the weakness of some structures in the national statistical apparatus, and (iii) insufficient resources for implementation of some priority actions.

By presenting its report in the form of a comparison between objectives, outcomes, and results, the aim of the government was to call on all its development partners and donors to draw lessons from this first year of PRSP implementation and, if necessary, adjust the programs and strategies for the coming years. 


\section{PRSP implementation context}

\subsection{General information}

The Central African Republic is a landlocked country in Central Africa. It measures $623,000 \mathrm{~km}^{2}$ and is bordered in the north by Chad, in the east by Sudan, in the south by the Congo and the Democratic Republic of the Congo, and in the West by Cameroon. It is located between $2^{\circ}$ and $11^{\circ}$ latitude north and $13^{\circ}$ and $27^{\circ}$ longitude east.

The population of the Central African Republic is ethnically diverse and the unifying factor is Sangö, the national language, which is spoken throughout the country. The population, which was estimated at $4,250,000$ inhabitants in 2007, is unevenly distributed, with an average density of 7 inhabitants per $\mathrm{km}^{2}$. The dependent population is in the majority, to the extent as those under 18 years of age and over the age of 60 represent 50 percent and 4 percent, respectively, of the total population.

Because of its geographic location, the Central African Republic benefits from favorable climatic conditions and is endowed with rich agricultural lands and enormous natural resources, such as wood, gold, and diamonds, the exploitation of which remains rudimentary and artisanal.

However, numerous military and political crises have seriously damaged the social and economic fabric and weakened the economic capacity of the government and the private sector. As a result, the Central African Republic is one of the least developed countries (LDCs), ranked 171st out of 177 countries according to the UNDP Report on the Human Development Index for 2007. The return to constitutional order in 2005 with the holding of free and transparent elections and the establishment of most of the republican institutions led to an easing of the political climate.

In this renewed climate of peace, the government has made poverty reduction the priority of its development policy since 2006, adopting its PRSP in September 2007 and reaching the decision point of the Heavily Indebted Poor Countries Initiative (HIPC) that same month.

\subsection{Social and economic characteristics}

Currently, a recovery is under way with the support of the international community, but it has been slow because of the enormous task of bringing the productive apparatus back into operation, particularly the basic infrastructure. However, the reforms undertaken by the government and implementation of successive programs have led to some progress with fiscal consolidation, a resumption of investment, and a recovery of consumption.

In 2007 , the economy remains dominated by the primary sector, particularly food production, livestock, hunting, and forestry, which produced more than 50 percent of national wealth. In the secondary sector, the extractive industries are dependent on global prices for metals.

In the area of trade, the Central African Republic offers basic cash crops (coffee and cotton), diamonds, gold, and timber as its main exports. Diamonds and timber represent almost 80 percent of export revenues. The share of national exports in world exports is 0.002 percent today, compared to 0.14 percent in 1965 , and the most important imports are oil products and food products, which explains the country's vulnerability to the global food and energy crises. These two groups of products represent 40 percent of the value of imports.

As for the budget, as an imperative for post-conflict recovery, the reforms undertaken by the government are today giving the public authorities access to greater budgetary resources for the operation of public 
services and investment. In 2007 revenues mobilized totaled CFAF 83.6 billion, or US\$167.2 million, against expenditures on the order of CFAF 68.5 billion, or US $\$ 137$ million.

Looking at the social situation, poverty affected close to 67.2 percent of the population in 2003 . This endemic poverty is more pronounced in rural areas, where the rate stood at 72 percent, than in urban areas (59 percent). Geographically, three regions have been identified as the most vulnerable in comparison with the rest of the country: region 3 (Ouham and Ouham-Pendé), region 5 (Haute-Kotto, Vakaga and Bamingui-Bangoran) and region 6 (Basse-Kotto, Mbomou and Haut-Mbomou). These are either regions with little economic potential, or areas affected by conflict.

The educational situation in 2007 was characterized by a net enrollment ratio of 51.4 percent at the primary level and a completion rate of 31 percent. The literacy rate for persons 15 to 24 years of age is 45.7 percent for boys and 25.9 percent for girls. In 2006 in the health sector, the key indicators showed the infant mortality rate at 106 per thousand, the infant and juvenile mortality rate at 176 per thousand, the maternal mortality rate at 1355 per hundred thousand live births, and the rate of births attended by medical personnel at 53.4 percent.

Access to road infrastructure remains very limited, with a density of paved roads of $0.17 \mathrm{~km}$ per thousand inhabitants. Similarly, just 7.8 percent of households have access to electricity.

\subsection{Review of the conclusions of the Brussels Round Table}

The Brussels Round Table Conference, held on October 26, 2007 at the initiative of the government, was aimed at launching an appeal to the international community to make it aware of the dramatic situation that Central African Republic could face and to invite it to support the C.A.R. in its post-conflict recovery efforts. The C.A.R. was supported in this approach by the European Commission, the UNDP, and the World Bank. The conference brought together representatives of 17 countries, 25 international organizations and financial institutions, and 2 NGOs.

Presentations made on (i) the economic and financial situation, (ii) the PRSP, and (iii) the new vision of a better partnership for coordination of ODA gave the participants an opportunity to assess the situation in the Central African Republic.

The government reaffirmed its intention of making poverty reduction the priority of all its development actions through implementation of the PRSP. It made commitments to the international community to create an environment favorable to mobilization of the necessary resources to implement the PRSP projects and programs. These commitments related in particular to:

- pursuit of the structural reforms undertaken to restore security and the rule of law, macroeconomic stabilization, completion of the HIPC Initiative, and improvement of governance with greater involvement of the private sector, civil society, and the general population;

- formal introduction and implementation of the institutional framework to accelerate the affirmation of national leadership in the implementation and evaluation/tracking of the PRSP, with an information system to track the living conditions of households, project and program implementation, and the impact of the strategy;

- prioritization of programs and projects, and organization of sectoral round tables and regular consultations to accelerate and consolidate the dialogue with the development partners.

The developer partners congratulated and encouraged the government in its efforts. They also promised bring their full support to the implementation of the PRSP and some gave quantitative indications of their financial contributions for the coming years, specifically the European Commission (EC), the World Bank, the AfDB, France, and the United Nations agencies. Other development partners indicated their 
willingness to make commitments later. Promised donations for the period 2008-2010 totaled more than US\$600 million. This support from the developer partners included:

- a financial contribution for the completion of programs and projects;

- technical and financial support for the PRSP evaluation/tracking and implementation institutional framework;

- support for the organization of sectoral round tables and regular consultations for the financing of PRSP programs and projects;

- consideration of all forms of bilateral and multilateral cooperation that could help with PRSP evaluation/tracking and implementation.

\subsection{Review of the midterm conclusions}

A midterm review of the Brussels commitments was organized on June 26, 2008 in Bangui to measure progress made. The PRSP outcomes since October 2007 were measured as well as the fulfillment of commitments, and a roadmap was prepared to frame the priority actions to be taken for the remainder of 2008

This initial assessment made it possible to measure progress made in achieving the programmed actions and to track mobilization of the announced resources.

\subsubsection{Key government achievements}

The review showed that substantial progress had been made in the areas of political, economic and financial governance and security:

- the preliminary global agreement to hold the Inclusive Political Dialogue was signed with the political and military groups, and the measures to ease tensions had been taken to promote this forum, which was intended to place the Central African Republic on the road to sustainable peace;

- financial and economic reform efforts were followed by fiscal measures, steps to manage the payroll, the securing of customs revenues, the Kimberly process, and the Extractive Industries Transparency Initiatives (EITI);

- the PRSP implementation laws/regulations were prepared and signed by the government, as well as laws/regulations specifying the missions, composition, and functioning of the sectoral committees. The national leaders of the sectoral committees and the lead managers of the development partners guiding the process for implementing the PRSP were also appointed;

- the National Seminar on the Reform of the Security Sector was organized, and its conclusions were translated into actions in the short and medium term to prepare the strategy for the sector.

\subsubsection{Key commitments of the development partners}

The assessment showed that US\$96 million, or 14 percent of the funds announced during the Round Table, were confirmed by the partners in agreements signed essentially by the United Nations agencies. Other more recent agreements have been concluded with the bilateral and multilateral partners and could increase the level of contributions.

\subsection{Conclusions of the annual review}

An annual review of the commitments of the Brussels Round Table for PRSP implementation was organized by the government on November 20, 2008 in Bangui. It responded to the concern expressed by the participants in the Brussels Conference for the need for ongoing dialogue and made it possible, one 
year after this important conference, to assess progress made in the implementation of the PRSP against the Brussels commitments.

This review gave the government, the development partners, and representatives of civil society and the private sector an opportunity to assess the start-up of the PRSP implementation process and the level of national ownership through presentations by the heads of the Sectoral Committees, on the basis of the four strategic pillars of the PRSP, the constraints hampering the process, and the volume and nature of resources mobilized.

The nine chairmen of the Sectoral Committees reviewed progress with PRSP implementation in their respective sectors namely: (i) reform of the security sector; (ii) governance; (iii) trade, private sector, regional integration, and employment; (iv) gender equality and poverty reduction; (v) rural development and food security; (vi) basic infrastructure; (vii) water and sanitation; (viii) education; and (ix) health and HIV/AIDS.

The main constraints revealed by these presentations are found both at the national level and with the development partners.

At the national level:

(i) difficulties related to the establishment of the PRSP institutional framework, particularly the Sectoral Committees, including their Thematic Groups, and the Regional Committees, which constitute the basic structures for implementation of the national poverty reduction strategy;

(ii) the still incomplete ownership of the strategy by the national stakeholders;

(iii) national weaknesses in the area of resource management and mobilization.

With the partners:

(i) often long and complex procedures hampering the rapid mobilization of resources needed for the programmed activities; and

(ii) the weakness of existing technical support to the sectoral committees.

The developer partners reaffirmed their commitment to supporting the government in the PRSP implementation process, and the stakeholders agreed to continue the dialogue on preparation of the Action Plan for implementation of the Paris Declaration.

The resources mobilized in late 2008 totaled US\$840 million, as compared US\$96 million at the midyear review. The share of resources corresponding to the PRSP period totaled US\$755 million, or 56.5 percent of the needs expressed at the Brussels Round Table. 


\section{Evaluation/tracking and institutional mechanism}

The general objective of the mechanism is to track and report on the impact of poverty reduction programs and policies on the living conditions of the population. Specifically this involves: (i) establishing an institutional PRSP tracking/evaluation mechanism, (ii) creating an information system to track/evaluate poverty reduction programs and results, and (iii) organizing community participation of all the stakeholders in developing programs and policies, tracking their implementation, and evaluating their impact.

\subsection{Institutional mechanism}

The implementation of PRSP programs and projects remains an ongoing concern of the government, and the establishment of an operational institutional framework is an important step in creating the permanent mechanisms for tracking the government's commitments and implementation of the priority programs.

The pilot institutional framework to track PRSP implementation was created by Prime Ministerial Decree 003 of March 12, 2008 and constitutes a step toward greater accountability at the national level and institutionalization of a dialogue framework with the Technical and Financial Partners (TFP). It includes: (i) a National Strategic Committee (CNS), (ii) a National Technical Committee (CMT), (iii) a National Technical Secretariat (STM), (iv) 9 Sectoral Committees (CS), and (v) 7 Regional Committees (CR).

The National Strategic Committee is chaired by the Prime Minister, giving it the ability to make decisions in real time. The fact that the second vice chairman is the U.N. Resident Coordinator is an indication of the government's commitment to maintaining the dialogue in a spirit of transparency. Likewise, the requirement that this committee report to the National Assembly on the results of its work helps to strengthen the participatory process. The National Technical Committee and the Sectoral Committees are balanced in their membership between the public sector, the development partners, the private sector, and civil society organizations. This structure makes the Regional Committees the foundation of participatory evaluation of implementation of the PRSP in particular and development projects in general and ensures their effectiveness in organizing and taking into account the necessary relations with the various parts of the government.

The complete mechanism is gradually being put in place. The CNS held its two annual sessions for 2008 (June and November). The chairman of the CMT organized awareness meetings with the development partners. The STN played its role in preparing the reports on the sessions of the CNS and the CMT and it also prepared and implemented a work program for the second half of 2008 and organized periodic meetings with the experts and Sectoral Committees. The Permanent Technical Secretariats (STPs) of the Sectoral Committees that are operating (security sector reform, gender equality and poverty reduction, trade, private sector and employment, water and sanitation, and basic infrastructure) have held their first sessions.

The constraints hampering the operations of the Sectoral Committees and other bodies are: (i) insufficient qualified staff, (ii) lack of premises and equipment (computers and peripherals), and (iii) insufficient financial resources.

\subsection{Evaluation/tracking tools and statistical apparatus}

\subsubsection{Statistical apparatus}

The evaluation/tracking mechanism provided in the PRSP follows the Results-Based Management (RBM) approach, which focuses on ongoing tracking of inputs, outcomes, outputs, results obtained from these outputs, and anticipated impact of the results. 
For purposes of PRSP evaluation/tracking, the various participants were grouped in an information system with three subsystems proposed by AFRISTAT in the Reference Framework and Common Minimum Methodological Guidelines (CRESMIC): (i) the "household living conditions tracking" subsystem; (ii) the "project and program implementation tracking" subsystem; and (iii) the "program and policy impact assessment" subsystem. These three subsystems complement each other and fit together perfectly.

The "household living conditions tracking" subsystem is headed by the C.A.R. National Statistical Institute (ICASEES) and groups the sectoral statistical units and the planning and research directorates of the sectoral ministries. This subsystem will be used to (i) produce reports on the results of the statistical survey operations, (ii) prepare the poverty tracking report, (iii) update the DevInfo database, and (iv) produce the report on progress and achievement of the MDGs. The programmed statistical operations are listed in the following table.

Table 1: Multiyear program of statistical surveys and operations for PRSP tracking

\begin{tabular}{|l|l|l|l|l|}
\hline Surveys and operations & $\mathbf{2 0 0 7}$ & $\mathbf{2 0 0 8}$ & $\mathbf{2 0 0 9}$ & $\mathbf{2 0 1 0}$ \\
\hline 1-2-3 survey (limited to phases 1 and 2) & & & $\mathrm{X}$ & \\
\hline CWIQ survey (ECASEB) & & $\mathrm{X}$ & & $\mathrm{X}$ \\
\hline Agricultural survey & & $\mathrm{X}$ & & \\
\hline Census of economic units & $\mathrm{X}$ & & & \\
\hline MICS survey & & & & $\mathrm{X}$ \\
\hline Health and population survey & & & $\mathrm{X}$ & \\
\hline Perception of poverty survey & & $\mathrm{X}$ & & $\mathrm{X}$ \\
\hline Diagnostic of the mining sector & & $\mathrm{X}$ & & \\
\hline Consumption budget survey & & & $\mathrm{X}$ & \\
\hline
\end{tabular}

Source: C.A.R. PRSP 2008-2010

Completion of the statistical operations planned for 2008 was expected to provide most of the PRSP evaluation/tracking indicators. However, only the CWIQ survey was carried out. The results will be available in May 2009 owing to constraints relating to: (i) the delayed purchase and availability of equipment (scanner and scales), (ii) the lack of technical assistance, and (iii) failure to master the technology and insufficient financial and logistical resources. The data collected are currently being processed and analysis will take place in May 2009 with the assistance of a World Bank consultant. The results will be used to define reference indicators (including the poverty profile) for tracking the PRSP. To enable ICASEES to carry out its mission effectively, it must finalize and implement the National Statistics Development Strategy (SNDS).

The "project and program implementation tracking" subsystem concentrates on physical and financial tracking. It is under the coordination of the General Director for Economic Programming, and the secretariat is provided by the Programming Directorate and Budget Directorate. It is responsible for production of (i) a project database, (ii) report on the aid management system (Development Assistance Database - DAD), (iii) a Development Cooperation Report (DCR) and (iv) a report on implementation of the Paris Declaration. The definition and choice of indicators for tracking poverty reduction projects carried out is one of the priorities of this subsystem, and for that purpose it must track the list of approximately 150 results and outcome indicators that were selected in two workshops (June and September 2008) and working sessions organized with the sectoral departments. These matrices have three key functions, namely, to enable: (i) ICASEES to feed the DevInfo database; (ii) managers to track and guide PRSP implementation; and (iii) the development partners to track efforts made and results obtained by the government

The "program and policy impact assessment" subsystem should make it possible to measure poverty reduction progress through (i) selective research reports on the impact of policies and programs, (ii) the 
PRSP implementation impact report and annual reports. This subsystem is coordinated by the STN and includes ICASEES, the General Directorate for Strategy and Policy, the planning directorates of the various ministries, civil society, and the private sector.

\subsubsection{Evaluation/tracking tools}

The main evaluation/tracking tools for the PRSP are the reporting system, the performance indicators, the DevInfo database, and the aid management and tracking system (DAD).

The reporting system has been developed and includes all outputs of the three subsystems mentioned above and the performance indicators of the sectoral and regional committees.

The current version of the performance indicators for tracking the PRSP and MDGs includes output indicators and results indicators.

The DevInfo database developed with the support of the U.N. agencies includes as many sub-databases as are needed. A provisional version of the database is gradually incorporating the PRSP tracking indicators.

The aide management system (DAD) that is being finalized should make it possible to provide better coordination and tracking of Official Development Assistance (ODA).

\subsection{The participatory tracking mechanism and active communications}

Development of the PRSP has given rise to many consultations and evaluations with all the stakeholders: the population, the government, nongovernmental organizations, civil society organizations, the private sector, and external partners. The government has undertaken to continue this participatory process during implementation of the strategy. Thus the aim of the communications and participation components is to create a dialogue that will promote involvement of all the development partners in the implementation and evaluation/tracking of the PRSP strategies and programs.

The participatory approach seeks to ensure ownership of the PRSP by the communities (representatives of grassroots communities, the private sector, civil society, the decentralized and devolved units of the government, and specific groups such as women, young people, persons living with HIV/AIDS, ethnic minorities, etc.) to make them accountable for their role and encourage their effective involvement and participation in the selection of policies and programs, priorities, and resources. It also involves identifying and encouraging their effective contributions to the outcomes, the evaluation/tracking of these outcomes, and consensual assessment of their impact. Finally this participatory approach contributes to the search for self-reliant development that will ensure sustainable reduction of poverty beyond the projects and programs currently under way. In this context, communications becomes a key tool for creating a forum in which to share knowledge, savoir-faire, and experience that strengthen the idea of a "community of destiny."

\subsubsection{Key outcomes}

Following the Brussels Round Table Conference, a campaign to disseminate and publicize the contents of the PRSP was launched. This campaign, which was directed at all stakeholders in the PRSP preparation process, took the form of meetings and workshops to enable the stakeholders to take ownership of the implementation strategies.

The regional workshops, which were held in the seven regional capitals, lasted four days each. An average of 60 persons participated in each workshop from all the communes in the regions concerned and 
identified by their status and/or professional activities. The operational objectives of the regional or local workshops were:

- to explain the stakes involved and implementation of the PRSP to representatives of the population, civil society and nongovernmental organizations (NGOs), the government, the private sector, associations representing specific social groups (young people, women, persons living with HIV aids, etc.) to mobilize them around the national poverty reduction strategy;

- $\quad$ on the basis of an analysis, to assess local priorities, related problems, and the best possible solutions;

- to encourage the participants to take ownership of the PRSP evaluation/tracking and implementation process by committing to it formally.

During the first dissemination campaign, which took place from January to March 2008, 2500 national strategy documents were distributed in six regional workshops. Workshops were organized in Bangui for the 120 members of the National Assembly, 40 representatives of the media (public and private), 35 civil society organizations, 40 junior parliamentarians, and 1500 public service managers.

To consolidate the PRSP institutional framework, missions were organized to help the population establish their Regional Committees. These missions provided an opportunity to meet/discuss with representatives of the various local stakeholders and exchange views with them on the modalities for establishing the Regional Committees. The discussions focused on interpreting the responsibilities of the Regional Committees described in Title V of Decree 003 of March 12, 2008 creating the Poverty Reduction Strategy Paper (PRSP) Evaluation/Tracking and Implementation Framework.

The main objective was to provide technical support to the populations in the regions as they established the PRSP Regional Committees by working with them to identify individuals to chair the governing bodies of the Regional Committees.

The interministerial missions, placed under the aegis of the Office of the Prime Minister, included representatives of the following departments: Ministry of the Interior and Public Security, the Office of the High Commissioner for Decentralization and Regionalization, and the Ministry of Planning, Economy, and International Cooperation. They were held in three phases and led to the establishment of the 7 Regional Committees in the administrative regions.

All the activities organized were covered by the public and private media. A communications strategy and action plan were prepared to disseminate information on the PRSP activities at all levels: national, regional, local, and international.

For communications purposes, time was reserved on radio and television for occasional broadcasts by the PRSP communications team and other stakeholders on PRSP activities. For the radio broadcasts, two hours were reserved on listener call-in talk shows twice a month, one hour for each language: Sangö and French. The first broadcasts involved the PRSP dissemination missions in December 2007. The MPECI website was also used to disseminate PRSP documentation. The creation of a magazine entitled "DSRP Actualité" (PRSP Update) completes the range of communications tools on all poverty reduction issues in the Central African Republic.

\subsubsection{Results obtained}

Completion of the various programmed activities created a real interest on the part of the population in all the regions visited, and the people expressed their willingness in taking part in the implementation of the national poverty reduction strategy. 
The public and the sectoral committees are becoming aware and beginning to involve themselves in the PRSP implementation process. In fact, some sectoral committees have developed their strategies and prepared a work program that could result in sectoral round tables.

The actions taken have begun to produce results. The participants (grassroots communities, local authorities, and civil society organizations) have recognized this as "an opportunity for each region to become involved in the development process and that not to take advantage of would be self-defeating given the healthy competition developing among the regions." As a result, each of them intends "to assume all its responsibilities," provided, they say, that the necessary resources are mobilized and that their effective involvement in the implementation of the strategy is guaranteed

\subsection{Capacity-building}

Capacity-building is the key to PRSP implementation, and a capacity-building program has been developed to ensure the institutional and technical effectiveness of the mechanism. It has six components: (ii) organizational and institutional capacity-building, (ii) technical capacity-building, (iii) development of the capacities of the participants, (iv) strengthening of the capacities of regional delegations responsible for two-way communications, (v) logistics, and (vi) management of motivations.

Organizational and institutional capacity-building should make it possible to establish and improve the functioning of the dialogue and guidance structures, particularly the National Statistics Council (CNS), the mission of which will be coordination and standardization. This council will be responsible for establishing nomenclatures, methodologies, concepts, and definitions for statistics and for conforming to international regulations. Organizational and institutional capacity-building also involves accurately defining the data-sharing responsibilities of the CNS, the CMT, the Sectoral Committees, and the Regional Committees.

Capacity-building is aimed at training all those involved in producing, processing, analyzing, and disseminating data to lead the three subsystems of the tracking/evaluation statistical apparatus through training workshops, seminars, and specific education programs leading to diplomas.

To revitalize the regional delegations, whose role is essential in the operation of the Regional Committees, capacity-building actions (training, provision of equipment and supplies) are proposed. Officials in these regional delegations will be trained in data collection using surveys and analysis of administrative records. This capacity-building will take place at the same time as that of the Sectoral Committees.

Logistical support will involve providing the PRSP structures with computer equipment/software and peripherals to support real-time processing of the data collected.

Management of motivations is an important part of providing encouragement to the staff of the bodies making up the PRSP evaluation/tracking institutional framework, in order to reward the true value of the efforts required to achieve the results.

Concrete capacity-building actions are already under way, with the training of middle management in statistics at ENAM, the launching of activities for the preparation of the National Statistics Development Strategy (SNDS), and multifaceted support from AFRISTAT on prices, national accounts, surveys, etc.

Finally, the PRSP Implementation Capacity-Building Project (ARCAD) is part of the capacity-building process. Focusing on capacity-building in the areas of planning, programming, budgeting, and tracking/evaluation, its contribution is key in the preparation of realistic, operational priority action plans. 


\section{Macroeconomic situation}

The Central African Republic's PRSP provides two reference macroeconomic frameworks. The first, the prudent scenario, is based on recent economic trends and underpins the economic program receiving assistance under the Poverty Reduction and Growth Facility (PRGF). The second so-called dynamic scenario is based on the government's commitment to reduce poverty substantially in the medium term.

Covering the period 2008-2010, the second scenario is based on a global recovery in all sectors and anticipates an annual average growth of 8.5 percent. This growth, which is intended to be pro-poor, should make it possible to significantly increase the income and well-being of the population. It is based on a recovery in the primary sector, essentially agriculture, whose contribution to overall growth is estimated at approximately 50 percent, and increased activity in the forestry and mining sectors. A recovery is also anticipated in the secondary sector, along with an increase in public investment in favor of the reconstruction of roads and production infrastructures and a resumption of private investment. In the tertiary sector, growth should result from the restoration of telecommunications services; reform of the trade sector with the promotion of forestry, mining and agricultural exports; and a recovery in the tourism sector.

\subsection{Macroeconomic trends}

According to 2008 estimates (see Table 2 below), this year has been characterized by a slowdown in growth and a resurgence of inflation. The real GDP growth rate is estimated at 2.8 percent, compared with 4.2 percent in 2007, a decline due in part to: (i) climatic conditions that were unfavorable to certain agricultural activities (irregular rainfall); (ii) a decline in activity in the water, electricity, and mining subsectors; (iii) delayed disbursements from the international community, despite the effective mobilization of donors at the Brussels Round Table in support of PRSP implementation; (iv) a high degree of dependence of government finance on the banking system notwithstanding the observed improvement in the mobilization of domestic resources; (v) the international financial crisis in the developed countries (United States and European countries) early in the second half of the year, which led to a contraction in global demand for basic export products; and (vi) the recent rise in the exchange rate of the euro against the American dollar, which had a negative impact on the competitiveness of export products.

Even the tertiary sector, which had seen sustained growth in 2007, slowed considerably. Annex 4 provides data on trends in real GDP growth rate by sector and indicates that very few sectors were able to sustain growth between 2007 and 2008.

Table 2: Key macroeconomic indicators

\begin{tabular}{|l|r|r|r|r|r|}
\hline \multirow{2}{*}{ Indicators } & $\mathbf{2 0 0 6}$ & $\mathbf{2 0 0 7}$ & \multicolumn{2}{c|}{2008} & \multicolumn{1}{c|}{$\begin{array}{c}\text { Spread between annual } \\
\text { variations in 2008 (estimates) }\end{array}$} \\
\cline { 3 - 5 } & & & Estimate & $\begin{array}{c}\text { PRSP } \\
\text { framework }\end{array}$ & \\
\hline GDP growth & $\mathbf{4 . 0 0}$ percent & $\mathbf{4 . 2 0}$ percent & $\mathbf{2 . 8 0}$ percent & $\mathbf{8 . 5 0}$ percent & $\mathbf{- 1 . 4 0}$ percent \\
\hline -Primary & 4.3 percent & 2.6 percent & 1.3 percent & & $\mathbf{- 1 . 3 0}$ percent \\
\hline -Secondary & 6.1 percent & 5.2 percent & 1.3 percent & & $\mathbf{- 3 . 9 0}$ percent \\
\hline -Tertiary & 3.8 percent & 7.6 percent & 5.0 percent & & $\mathbf{- 2 . 6 0}$ percent \\
\hline Investment rate & $\mathbf{1 0 . 2}$ percent & $\mathbf{1 0 . 3}$ percent & $\mathbf{1 2 . 1}$ percent & $\mathbf{2 3 . 8}$ percent & $\mathbf{1 . 8 0}$ percent \\
\hline Inflation rate & $\mathbf{6 . 6}$ percent & $\mathbf{1 . 0}$ percent & 9.3 percent & & $\mathbf{8 . 3 0}$ percent \\
\hline
\end{tabular}

Source: $C T P / P A S, C E M A C$ 
The resurgence of inflation results from (i) the world food crisis that followed the increase in the price of staples, and (ii) the rise in oil prices in the first half of 2008 to the record level of US\$147 per barrel in July before beginning a downward trend.

Box 1 below presents the dynamic PRSP scenario.

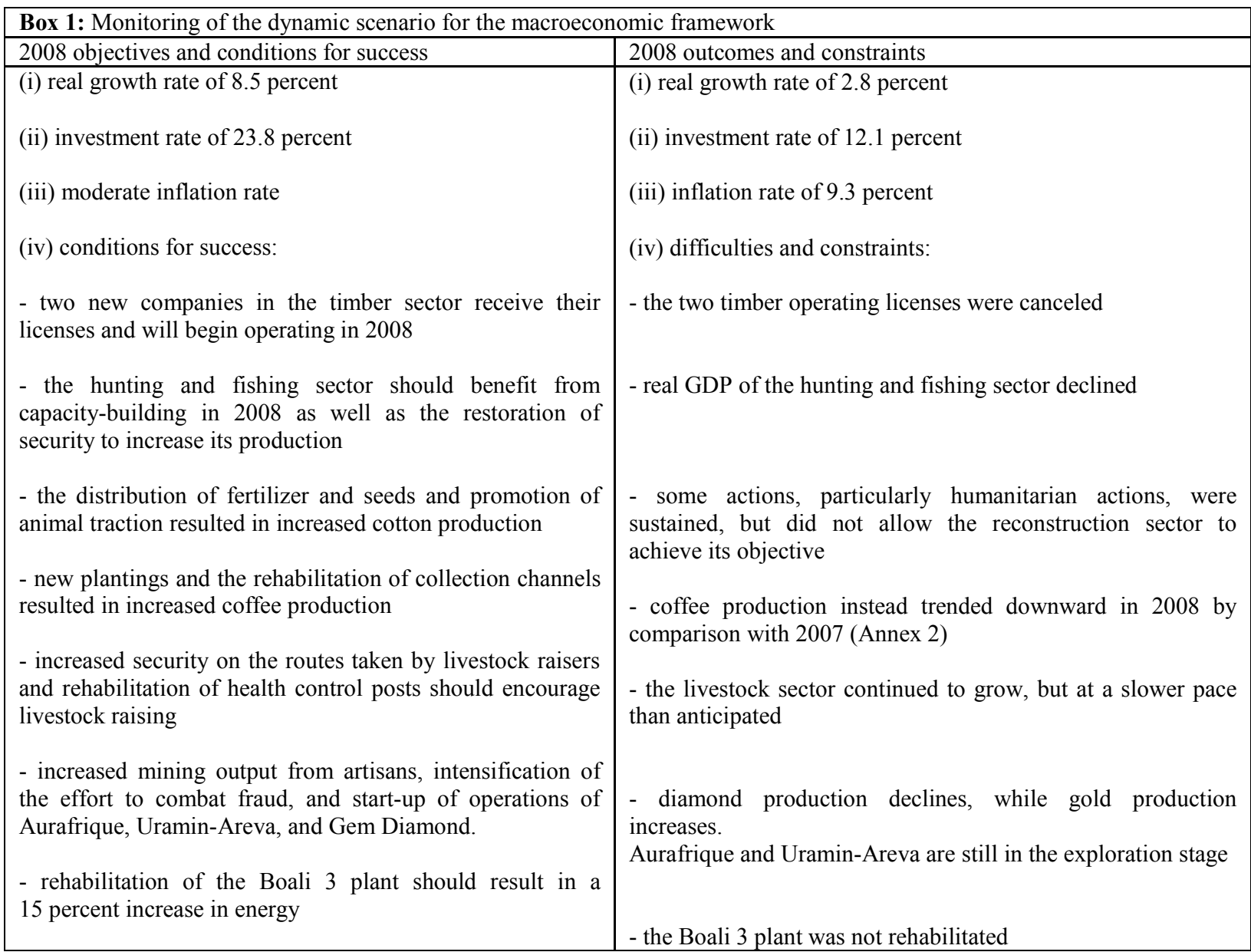

Estimated growth rate trends in 2008 also show the gap with the PRSP framework forecasts. The PRSP framework, which anticipated a growth rate of 8.5 percent, was justified by a vast investment program in key sectors such as (i) rural development and the development centers, (ii) transportation and infrastructure, (iii) energy and mining, and (iv) security. The growth rate of 8.5 percent corresponded to an investment rate of 23.8 percent. Outcomes show that it could not be met. The government recognizes that the conditions for achieving the projected economic growth rate were not there in 2008 and some obstacles remain, in particular: (i) the structural environment of the C.A.R. economy (landlocked, underequipped, lack of security, etc.), (ii) delays in the rehabilitation of basic infrastructure (roads, energy, communications, etc.), (iii) delays in the improvement of absorptive capacities, and (iv) constraints still hampering the effectiveness of ODA. Aware of the fact that poverty reduction will not be achieved without strong, sustainable growth, the government intends to revise this dynamic scenario to channel opportunities that will enable it to double the investment rate in the medium term.

Prices rose in 2008 and the inflation rate was estimated at 9.3 percent, compared to 1 percent in 2007. This was due in part to the commodity crisis, particularly the sharp rise in oil prices, which reached a record level of US\$147 in July 2008, as well as shortages of some food products owing to global price increases. 
Government measures to lower the Value Added Tax (VAT) from 19 percent to 5 percent on food and oil products helped to ease inflation.

\subsection{Foreign trade}

The international economic context in 2008 affected the Central African Republic's foreign trade, both imports and exports.

The value of exports of goods and services in 2008 was estimated at US\$202.4 million, or CFAF 101.2 billion, compared with US\$244.4 million, or CFAF 122.2 billion, in 2007, a decline of 17.2 percent from 2007. Two factors help to explain this trend: (i) the declining volume for the main export products, particularly timber, diamonds, and coffee, and (ii) the depreciation of the dollar vis-à-vis the euro.

Imports of goods and services totaled US\$455 million (CFAF 227.5 billion) in 2008 compared with US\$369 million (CFAF 184.5 billion) in 2007, a 23.3 percent increase explained by: (i) the higher volume of imports of key staples and investment goods, and (ii) the rise in import prices, particularly owing to higher transportation costs.

The rise in imports combined with the decline in exports led to a deterioration in the trade balance. The overall trade deficit increased from US\$122 million (CFAF 61 billion) in 2007 to US\$226 million (CFAF 113 billion) in 2008. The impact of this worsening deficit on the country's foreign assets has been mitigated by the fact that these imports come for the most part from the CEMAC zone.

\subsection{Monetary situation}

The monetary situation as at December 2007 was characterized by: (i) a 3.8 percent contraction in the money supply, which was estimated at US\$236.8 million, or CFAF 118.4 billion, in 2007, compared with US\$246 million, or CFAF 123 billion, one year earlier; (ii) a decline in net foreign assets of 26.5 percent during the same period, from US\$86 million (CFAF 43.0 billion) to US $\$ 63.2$ million (CFAF 31.6 billion); and (iii) a 6 percent increase in domestic credit owing essentially to government borrowing from local banks to cover the payroll taxes on its operations.

At the end of 2008, net foreign assets had declined 2.8 percent from 2007 levels, although this decline is modest compared to the average in the CEMAC subregion. During the period under review, credit to the economy rose 10.3 percent, from US\$118.2 million, or CFAF 59.1 billion, to US\$130.4 million, or CFAF 65.2 billion. The C.A.R. has the lowest rate of coverage of lending by deposits ( 93.9 percent) of the CEMAC zone. Finally, the government's indebtedness to the banking system deteriorated by 17.2 percent in a region where governments are generally creditors, although the situation in the zone has worsened somewhat from 2007.

\subsection{Fiscal position}

The government undertook to boost the level of public revenues from 9.0 percent of GDP in 2006 to 12.6 percent in 2010. This increase was to be based essentially on increased economic activity, expansion of the tax base, and improved performance of the tax administrations, and it was to lead to a better distribution of national revenue in favor of the poorest segments of the population. The strategy to be put in place in support of this objective was to continue the reforms begun with the Bretton Woods Institutions, particularly government divestiture and reform of the financial administrations, which were also supported by the European Union. 
Fiscal revenues have been increasing since 2006, rising from US\$146.8 million, CFAF 73.4 billion, in 2006, to US\$167.2 million, CFAF 83.6 billion, in 2007, an increase of 14 percent. Expenditure in 2007 stood at US\$206.2 million, or CFAF 103.1 billion, a decline of 5.2 percent from 2006. This contraction is explained by the drastic drop in investment expenditure owing to the difficulties in mobilizing external financing, the amount of which at US\$40.4 million (CFAF 20.2 billion) in 2007 was a 33.2 percent decline from 2006 (US\$60.4 million, CFAF 30.2 billion).

The 2008 budget calls for US\$197 million, or CFAF 98.5 billion, in revenues (11 percent of GDP), an increase of 17.8 percent over 2007. Domestically financed expenditure is set at approximately US\$194.4 million, or CFAF 97.2 billion, an annual increase of 11 percent. This will lead to an overall fiscal deficit of about US\$32 million, or CFAF 16 billion, for 2008.

Primary expenditure in 2008 totaled US\$161.2 million (CFAF 80.6 billion) compared with US\$136.2 million (CFAF 68.1 billion) in 2007, an increase of 18.3 percent. Revenues collected totaled US\$184 million (CFAF 92 billion), compared with US\$167.2 million (CFAF 83.6 billion) in 2007. This 10 percent increase is the result of improved tax revenues, while nontax revenues declined slightly.

The gradual restoration of external solvency has been achieved through the clearance of arrears and a three-year grace period on bilateral debt to the Paris club. In addition, the Central African Republic could soon benefit from the HIPC Initiative. Outstanding debt increased by 0.7 percent between 2007 and 2008, from US\$961.4 million (CFAF 480.7 billion) to US\$968.6 million (CFAF 484.3 billion), while debt service declined by 23.8 percent over the same period from US\$56.4 million (CFAF 28.9 billion) to US\$44 million (CFAF 22 billion).

In 2007, the Central African Republic satisfied two of the four convergence criteria for the CEMAC: (i) basic fiscal balance as a percentage of GDP of 0.5 percent (standard > zero) and (ii) average annual inflation rate of 1 percent (standard $<3$ percent). For the other two criteria, namely, (iii) total outstanding public debt as compared to nominal GDP (85.4 percent) and (iv) accumulation of external arrears (US\$16 million or CFAF 8 billion), the situation deteriorated somewhat from the previous year. The first two criteria showed a marked improvement, continuing the trend of recent years, while the deterioration in the third criterion marks a contrast with the strong downward trend of the past three years.

Although the first convergence criterion was achieved in 2008 (fiscal balance equal to 0.56 percent of GDP), the inflation, rate of 9.3 percent is above the community standard (3 percent). Likewise, while the debt/GDP ratio declined from 84.5 percent in 2007 to less than 80 percent in 2008 , this still above the community standard.

\section{PRSP financing}

\subsection{Mobilization of domestic resources}

The state budget is the main source of financing for the government's strategy. Domestic resources remain relatively modest, owing to the various conflicts that the country has faced in recent years, which considerably weakened the government and its apparatus. When it presented its PRSP at the Brussels Round Table, the government hoped its partners would provide the necessary resources for its implementation. Despite the difficult economic situation, it is committed to continuing its own efforts toward poverty reduction, some of which were begun long before the adoption of the PRSP.

As soon as the strategy was adopted, the government rapidly took steps to implement certain actions with domestic financing, particularly reform measures, reflecting the political will of the public authorities to do everything possible to implement the key pillars of its strategy to substantially reduce poverty. The following table shows its fiscal potential in the past two fiscal years. 
Table 3: Domestic resources 2007-2008 (in CFAF billion)

\begin{tabular}{|l|r|r|r|}
\hline \multirow{2}{*}{ Headings } & $\mathbf{2 0 0 7}$ & $\mathbf{2 0 0 8}$ & \\
\cline { 2 - 3 } & Outcomes & Estimates & Rate of change \\
\hline Total revenues & $\mathbf{8 3 . 6}$ & $\mathbf{9 2 . 5}$ & $\mathbf{1 0 . 6}$ percent \\
\hline Tax revenues & $\mathbf{6 6 . 6}$ & $\mathbf{7 0 . 7}$ & $\mathbf{6 . 1}$ percent \\
\hline Taxes on income and profits & 13.1 & 14.6 & 11.5 percent \\
\hline Taxes on goods and services & 31.9 & 33.9 & 6.3 percent \\
\hline Taxes on international trade & 14.5 & 16.5 & 13.8 percent \\
\hline Other tax revenues & 7.1 & 5.7 & -20.2 percent \\
\hline Nontax revenues & $\mathbf{1 7 . 0}$ & $\mathbf{2 1 . 8}$ & $\mathbf{2 8 . 5}$ percent \\
\hline
\end{tabular}

Source: $C T P / P A S$

The projected increase in resources in 2008 over 2007 would result from the anticipated rise in tax revenues (21.3 percent) owing to the implementation of some tax and customs measures in the new budget law, effective application of all the recommendations of the audit reports on the Douala one-stop shop, the VAT, and the Public Treasury reform. The increase in tax revenues is estimated at 6.1 percent in 2008 . Although this result is weak, it is to the credit of the government, which made the effort to mobilize resources despite the sluggishness of the international economic context.

\subsection{Structure of public expenditure}

Budgetary allocations have been rationalized, both by nature and by sector. Looking at 2007 and 2008, it is evident that allocations have been made rationally to achieve the objectives of the strategy.

Investment expenditure allocations in the budget increased 21.6 percent from 2007 to 2008 , although total resources rose only 10 percent in the same period (see Table 4). This budgetary structure reflects the willingness of the public authorities to control operating expenditures seen as unproductive, while favoring investment, which finances the creation of wealth and development. Investments totaled US\$86.6 million (CFAF 43.3 billion) in 2008, compared with US\$38 million (CFAF 19 billion) and US\$75 million (CFAF 37.5 billion) for purchases of goods and services and remuneration of personnel, respectively. Wages increased 7 percent over 2007 in the context of recruitment and training in the education sector.

Table 4: Budgetary allocations by type of expenditure (in CFAF billion)

\begin{tabular}{|c|l|r|r|r|r|r|}
\hline \multirow{2}{*}{ Title } & \multirow{2}{*}{ Chapter } & \multicolumn{2}{|c|}{$\mathbf{2 0 0 7}$} & \multicolumn{2}{|c|}{$\mathbf{2 0 0 8}$} & \multirow{2}{*}{ Change } \\
\cline { 3 - 6 } & & Amount & Structure & Amount & Structure & 2008/2007 \\
\hline $\mathbf{1}$ & Personnel & 35.0 & 25.6 percent & 37.5 & 24.8 percent & 7.1 percent \\
\hline $\mathbf{2}$ & Operations & 15.9 & 11.6 percent & 19.1 & 12.6 percent & 20.1 percent \\
\hline $\mathbf{3}$ & Financial costs & 6.4 & 4.7 percent & 8.7 & 5.8 percent & 35.9 percent \\
\hline $\mathbf{4}$ & Intervention & 17.9 & 13.1 percent & 20.1 & 13.3 percent & 12.3 percent \\
\hline $\mathbf{5}$ & Investment & 35.6 & 26.0 percent & 43.3 & 28.7 percent & 21.6 percent \\
\hline $\mathbf{6}$ & Debt repayment & 26.0 & 19.0 percent & 22.3 & 14.8 percent & -14.2 percent \\
\hline & Grand total & $\mathbf{1 3 6 . 8}$ & 100.0 percent & $\mathbf{1 5 1 . 0}$ & 100.0 percent & 10.4 percent \\
\hline
\end{tabular}

Source: General Directorate of the Budget

The share of resources allocated to debt repayment declined by 14 percent from 2007 to 2008, reflecting the negotiations for debt cancellation and relief after the C.A.R. reached the decision point under the HIPC Initiative in September 2007. 
As far as sectoral allocations of expenditures are concerned, analysis of the situation in the priority sectors, namely, national education, public health and population, social affairs, and rural development, between 2007 and 2008 shows an improvement in the resources allocated to these sectors (see Table 5 below).

Table 5: Budgetary allocations in the priority sectors (CFAF million)

\begin{tabular}{|c|c|c|c|c|c|c|}
\hline \multirow[b]{2}{*}{ Priority sectors } & \multicolumn{2}{|c|}{2007} & \multicolumn{2}{|c|}{2008} & \multicolumn{2}{|c|}{$\begin{array}{l}\text { Rate of achievement during the first } \\
\text { nine months of } 2008 \text { in percent }\end{array}$} \\
\hline & Allocations & $\begin{array}{c}\text { Share } \\
\text { in percent }\end{array}$ & Allocations & $\begin{array}{c}\text { Share } \\
\text { in percent }\end{array}$ & $\begin{array}{l}\text { Without } \\
\text { arrears }\end{array}$ & With arrears \\
\hline $\begin{array}{l}\text { National } \\
\text { education }\end{array}$ & 11,382 & 13.6 & 13,256 & 13.5 & 74.8 percent & 92.0 percent \\
\hline -Operations & 10,924 & 13.1 & 11,990 & 12.2 & 89.7 percent & 110.3 percent \\
\hline -Investment & 458 & 0.5 & 1,266 & 1.3 & 0.0 percent & 0.0 percent \\
\hline $\begin{array}{l}\text { Public health and } \\
\text { population }\end{array}$ & 6,798 & 8.1 & 12,061 & 12.2 & 40.1 percent & 43.7 percent \\
\hline -Operations & 6,501 & 7.8 & 7,130 & 7.2 & 109.9 percent & 120.1 percent \\
\hline -Investment & 297 & 0.4 & 4,931 & $\overline{5.0}$ & 1.5 percent & 1.5 percent \\
\hline Social affairs & 831 & 1.0 & 3,063 & 3.1 & 12.8 percent & 17.0 percent \\
\hline -Operations & 730 & 0.9 & 802 & 0.8 & 89.7 percent & 119.1 percent \\
\hline -Investment & 101 & 0.1 & 2,261 & 2.3 & 0.0 percent & 0.0 percent \\
\hline $\begin{array}{l}\text { Rural } \\
\text { development }\end{array}$ & 2,438 & 2.9 & 3,134 & 3.2 & 54.6 percent & 65.3 percent \\
\hline -Operations & 2,193 & 2.6 & 2,373 & 2.4 & 89.6 percent & 108.2 percent \\
\hline -Investment & 245 & 0.3 & 761 & 0.8 & 6.9 percent & 6.9 percent \\
\hline $\begin{array}{l}\text { Total for priority } \\
\text { sectors }\end{array}$ & 21,449 & 25.7 & 31,514 & 32.0 & 51.2 percent & 60.8 percent \\
\hline $\begin{array}{l}\text { TOTAL } \\
\text { GOVERNMENT } \\
\text { BUDGET }\end{array}$ & 83,600 & 100.0 & 98,500 & 100.0 & & \\
\hline
\end{tabular}

As shown in Table 5 above, outcomes in the priority sectors come to approximately 51 percent of forecast allocations. The share of these sectors in the overall budget increased from 25.7 percent in 2007 to 32 percent in 2008. The allocations for 2008, which were decided in 2007 when the budget was being prepared, were already beginning to take account of the PRSP priorities, particularly in the public health and social affair sectors, the shares of which increased from 8.1 percent to 12.2 percent and from 1 percent to 3.1 percent, respectively. The share of resources allocated to education did not increase substantially, but a rebalancing between operations and investment, the share of which tripled, made it possible to focus on the objective of rehabilitating school infrastructures.

\subsection{Mobilization of external financing}

To promote strong, sustainable growth at an average annual rate of 8.5 percent beginning in 2008 and to improve the well-being of the population of the Central African Republic, the government has set a very ambitious macroeconomic and budgetary framework in the Poverty Reduction Strategy Paper (PRSP). This stated willingness of the government to confront the situation head on gave rise to the dynamic PRSP scenario. The resources that need to be mobilized to achieve the objectives of growth and poverty reduction for the period of 2008-2010 under this scenario are substantial. 
Based on September 2007 estimates, the expenditures needed to implement the PRSP four pillars total approximately US $\$ 1.3$ billion, or CFAF 633 billion, distributed as shown in Table 6 below

Table 6: Project costs by PRSP pillar (US\$1 = CFAF 475)

\begin{tabular}{|c|c|c|c|c|c|c|}
\hline \multirow[b]{2}{*}{ Pillars } & \multicolumn{4}{|c|}{ CFAF billion } & \multicolumn{2}{|c|}{ US\$ million } \\
\hline & 2008 & 2009 & 2010 & Total & Total & percent \\
\hline $\begin{array}{l}\text { Consolidation of peace and conflict } \\
\text { prevention }\end{array}$ & 8.6 & 10.4 & 15.6 & 34.6 & 72.9 & 5.5 \\
\hline Governance and the rule of law & 8.9 & 10.7 & 16 & 35.7 & 75.2 & 5.6 \\
\hline $\begin{array}{l}\text { Economic recovery and } \\
\text { diversification }\end{array}$ & 104.9 & 125.8 & 188.8 & 419.6 & 883.5 & 66.3 \\
\hline Development of human capital & 35.8 & 43 & 64.5 & 143.3 & 301.8 & 23.6 \\
\hline Total & 158.3 & 190 & 285 & 633.4 & $1,333.5$ & 100 \\
\hline
\end{tabular}

Source: : Ministry of Planning, Economy, and International Cooperation

Analysis of the distribution of needs by pillar shows that Pillar III, which deals with economic recovery and diversification, captures 66 percent of total resources, reflecting the importance of the pillar in terms of areas covered and the priority given to promoting growth (see Chart 1). The challenge for this pillar encompasses the challenge of attracting the private sector, whose investments are essential to extending the action of the government in favor of the productive sectors. Next, Pillar IV on development of human capital requires 23.6 percent, showing the interest in boosting the social sectors and supporting improvements in productivity. These two pillars capture more than 90 percent of the overall allocation, with the other two pillars (I and II) sharing the remaining 10 percent of resources.

\section{Chart 1: Distribution of financing needs by pillar}

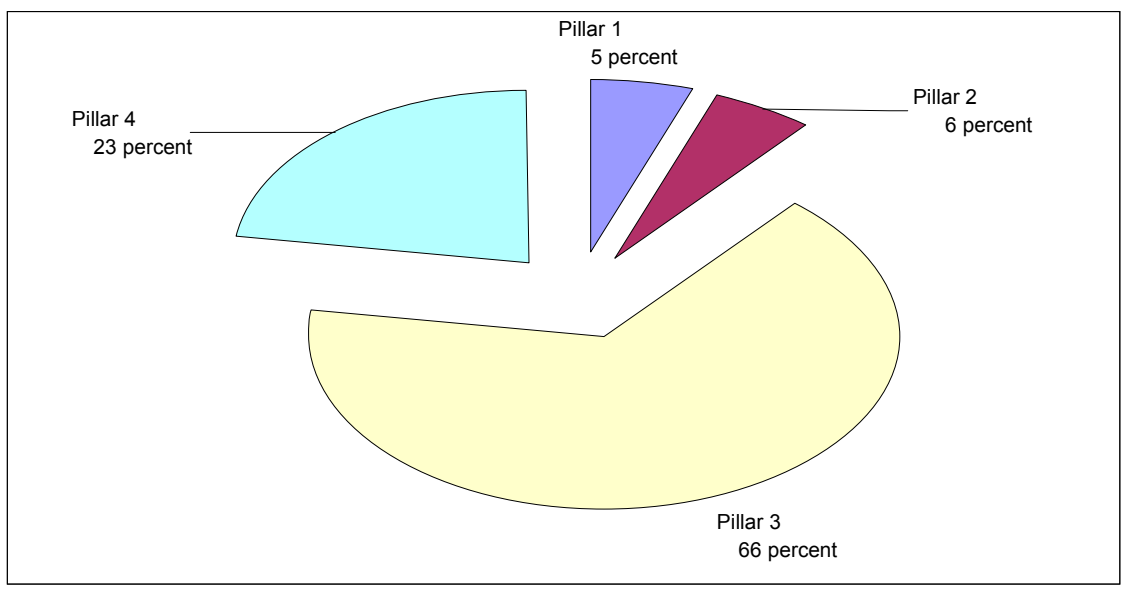

The trend observed in the expression of needs over the period 2008-2010 shows a rate of increase that is in line with the gradual maturation of projects to be carried out as the PRSP is implemented, which is no longer reflected in the rate of commitments (see Table 7). 
Table 7: Financing obtained compared with estimated commitments

\begin{tabular}{|l|r|r|r|r|r|r|r|r|r|r|r|}
\hline \multirow{2}{*}{ Pillar } & \multicolumn{4}{|c|}{ Commitments in US\$ million } & \multicolumn{3}{c|}{ Mobilizations in US\$ million } & \multirow{2}{*}{$\begin{array}{c}\text { Financing } \\
\text { gap }\end{array}$} \\
\cline { 2 - 12 } & $2008\left(^{*}\right)$ & 2009 & 2010 & Beyond & Total & $2008\left(^{*}\right)$ & 2009 & 2010 & $\begin{array}{r}\text { Beyond } \\
\text { Total }\end{array}$ \\
\hline Consolidation of peace & 31.2 & 4.5 & 12.3 & & 48 & 49.7 & 12 & 17.3 & & 79 & $34.2 \%$ \\
\hline $\begin{array}{l}\text { Governance and the rule } \\
\text { of law }\end{array}$ & 15.3 & 7 & 23.2 & & 45.5 & 37.9 & 6.8 & & & 44.7 & $39.5 \%$ \\
\hline Economic recovery & 272.3 & 93.9 & 32.1 & 69 & 467.3 & 180.1 & 202.2 & 21.1 & 20.1 & 423. \\
5 & $54.9 \%$ \\
\hline Human capital & 71.3 & 48 & 57.6 & & 176.9 & 135 & 53.6 & 39.7 & 64.5 & 292. \\
8 & $41.4 \%$ \\
\hline Total & $\mathbf{3 9 0 . 1}$ & $\mathbf{1 5 3 . 4}$ & $\mathbf{1 2 5 . 2}$ & $\mathbf{6 9}$ & $\mathbf{7 3 7 . 7}$ & $\mathbf{4 0 2 . 7}$ & $\mathbf{2 7 4 . 6}$ & $\mathbf{7 8 . 1}$ & $\mathbf{8 4 . 6}$ & $\mathbf{8 4 0}$ & $\mathbf{4 9 . 9 \%}$ \\
\hline
\end{tabular}

(*) Including prior to 2008

Source: Ministry of Planning, Economy, and International Cooperation

Committed or announced financing corresponds to close to 55 percent of total needs expressed, leaving a financing gap of 45 percent. However, if we look only at PRSP implementation, this gap increases to almost 50 percent. An analysis shows that the financing gap is largest for the third pillar (55 percent), showing how little the sectors for this pillar were considered in the areas of concentration of ODA in the Central African Republic. The government hopes to take this into account when budgetary allocations of domestic resources are made, while at the same time it will plead with some donors to ask them to support these growth sectors.

The resources actually mobilized by the signing of a financing agreement on November 15, 2008 total US\$840 million, including US\$402 million for 2008. The 2008 amount takes into account the resources mobilized for 2007 and 2008, in the amount of US\$203 million and US\$199 million, respectively. The fact that some pillars have committed resources exceeding needs or mobilized resources exceeding commitments is explained by the cooperation frameworks signed between the government and some donors prior to 2008, and humanitarian aid, the flow of which is growing. The same explanation holds true for the pillars that benefit from disbursed resources exceeding mobilized resources. US\$755.4 million have been mobilized for the period 2008-2010.

The mobilization of resources involves both the government and the development partners. The government intends to takes various actions to meet these challenges, particularly structural reforms under the PRSP, preservation of the climate of peace and socioeconomic stability that are essential for all development actions, development and implementation of sectoral strategies and policies that are consistent with the PRSP and that take account of the MDGs, and development and launching of an intense communications campaign to mobilize the additional resources needed for implementation of the PRSP and MDGs. The partners for their part are asked to increase their financial support, to align that support to national priorities, and to ease disbursement conditions and procedures.

\subsection{Status of commitments, payments, and expenditures in 2008}

Provisional data on commitments, payments, and expenditures distributed among the four pillars of the PRSP for 2008, and their respective areas, are indicated in Table 8 below, which shows the various outcomes achieved with development aid as compared with humanitarian aid. 
Table 8: Status of commitments, payments, and expenditures in 2008 (US\$ million)

\begin{tabular}{|c|c|c|c|c|c|}
\hline Type & Pillar & Area & Commitments ${ }^{i}$ & Payments if & Expenditures ${ }^{\text {if }}$ \\
\hline \multirow{19}{*}{ Development aid } & $\begin{array}{l}\text { Security, peace, } \\
\text { and justice }\end{array}$ & Security, peace, and justice & 28.83 & 27.87 & 21.59 \\
\hline & \multicolumn{2}{|l|}{ Total Pillar 1} & 28.83 & 27.87 & 21.59 \\
\hline & \multirow{4}{*}{$\begin{array}{l}\text { Governance and } \\
\text { the rule of law }\end{array}$} & Business environment & 4.17 & 5.82 & 3.15 \\
\hline & & Governance & 21.53 & 47.46 & 44.66 \\
\hline & & Population and gender & 0.62 & 1.11 & 1.06 \\
\hline & & Other (project audits, etc.) & 1.94 & 1.99 & 2.21 \\
\hline & \multicolumn{2}{|l|}{ Total Pillar 2} & 28.27 & 56.38 & 51.07 \\
\hline & \multirow{7}{*}{ Economy } & Arts and culture & 1.04 & 1.04 & 0.98 \\
\hline & & World development & 6.70 & 3.87 & 4.53 \\
\hline & & Water and sanitation & 5.71 & 4.78 & 4.48 \\
\hline & & Energy & 1.19 & 2.25 & 1.08 \\
\hline & & Forests & 3.06 & 7.70 & 4.54 \\
\hline & & Minds & 0.96 & 0.96 & 0.96 \\
\hline & & $\begin{array}{l}\text { Transportation and } \\
\text { infrastructure }\end{array}$ & 36.48 & 13.31 & 20.14 \\
\hline & Total Pillar 3 & & 55.12 & 33.91 & 36.70 \\
\hline & \multirow{3}{*}{ Human capital } & Education & 7.72 & 6.92 & 5.55 \\
\hline & & Health & 51.50 & 33.69 & 21.66 \\
\hline & & HIV/AIDS & 3.26 & 13.45 & 9.87 \\
\hline & Total Pillar 4 & & 62.48 & 54.07 & 37.08 \\
\hline \multicolumn{3}{|c|}{ Total development aid } & 174.69 & 172.22 & 146.44 \\
\hline \multirow{8}{*}{$\begin{array}{l}\text { Humanitarian } \\
\text { aid }\end{array}$} & \multicolumn{2}{|c|}{$\begin{array}{l}\text { Multisectoral assistance for refugees and displaced } \\
\text { persons }\end{array}$} & 4.75 & 4.67 & 4.64 \\
\hline & \multicolumn{2}{|c|}{ Coordination, logistics, and common fund } & 17.89 & 17.03 & 8.44 \\
\hline & \multicolumn{2}{|c|}{ Water and sanitation } & 2.92 & 2.40 & 1.60 \\
\hline & \multicolumn{2}{|l|}{ Education } & 8.51 & 2.76 & 2.68 \\
\hline & \multicolumn{2}{|l|}{ Protection } & 1.33 & 1.21 & 1.29 \\
\hline & \multicolumn{2}{|c|}{ Recovery and infrastructure } & 3.06 & 2.46 & 1.47 \\
\hline & \multicolumn{2}{|l|}{ Health } & 4.57 & 4.84 & 5.45 \\
\hline & \multicolumn{2}{|c|}{ Food security and agriculture } & 43.13 & 42.39 & 26.77 \\
\hline \multicolumn{3}{|c|}{ Total humanitarian aid } & 86.16 & 77.76 & 52.34 \\
\hline \multicolumn{3}{|c|}{ Grand Total } & 260.85 & 249.99 & 198.78 \\
\hline
\end{tabular}

Source: Ministry of Planning, Economy, and International Cooperation (DAD).

\section{Box 2. Definition of OECD terminology}

Commitments: A firm obligation, expressed in writing in the year in question, undertaken by an official donor to provide specified assistance to a recipient country, multilateral organization, or nongovernmental organization, along with specific financial conditions and for specific purposes Commitments are recorded in the full amount of the expected transfer, irrespective of the time required for the completion of payments.

${ }^{i i}$ Payments: The provision of resources to an implementation agency or disbursement of funds by the public sector. Payments are recorded in the full amount of the transfer, irrespective of the time requirement to complete the expenditures. For regular resources of U.N. agencies, the inclusion of the resources in the accounting system constitutes payment.

iii Expenditures: Transfers in cash or in cash equivalents to beneficiaries or implementation agencies for the provision of goods or services as shown in invoices, receipts, vouchers or other similar accounting documents. 
Box 3. Constraints owing to the provisional nature of the DAD data

It should be noted that commitments and payments may cover multiyear actions. This makes it difficult to compare commitments, payments, and expenditures at this time owing to the following constraints:

- the transition toward the ODA management system (DAD) began only in the third quarter of 2008. As a result, the figures used in the DAD based on the OECD codification are not necessarily comparable to those initially collected manually, although the DAD was able to record 80 percent of data for 2008 ;

- the accounting systems of many of our partners do not for the moment provide reliable data prior to March 15, 2008;

- the deadline for the release of the first reports with 95 percent reliability by the DAD system is expected in April 2009; this constraint nonetheless puts us a step ahead of the OECD, which typically will present its 2008 figures during the third quarter of 2009 .

Humanitarian aid continued to account for a substantial share of the foreign assistance received by the Central African Republic in 2008 (see Chart 2), at 26 percent. It is concentrated in the area of food security and agriculture. The distribution of development aid expenditures confirms the critical situation in Pillar 3 (25 percent), although it is wealth-creating for poverty reduction (see Chart 3 ). The governance sector was a focus in 2008 with 35 percent of expenditures targeting the many reforms conducted by the government during the period. The security and peace and health sectors follow with 15 percent, respectively, of expenditure.

\section{Chart 2: Distribution of expenditure in 2008 (in percent)}

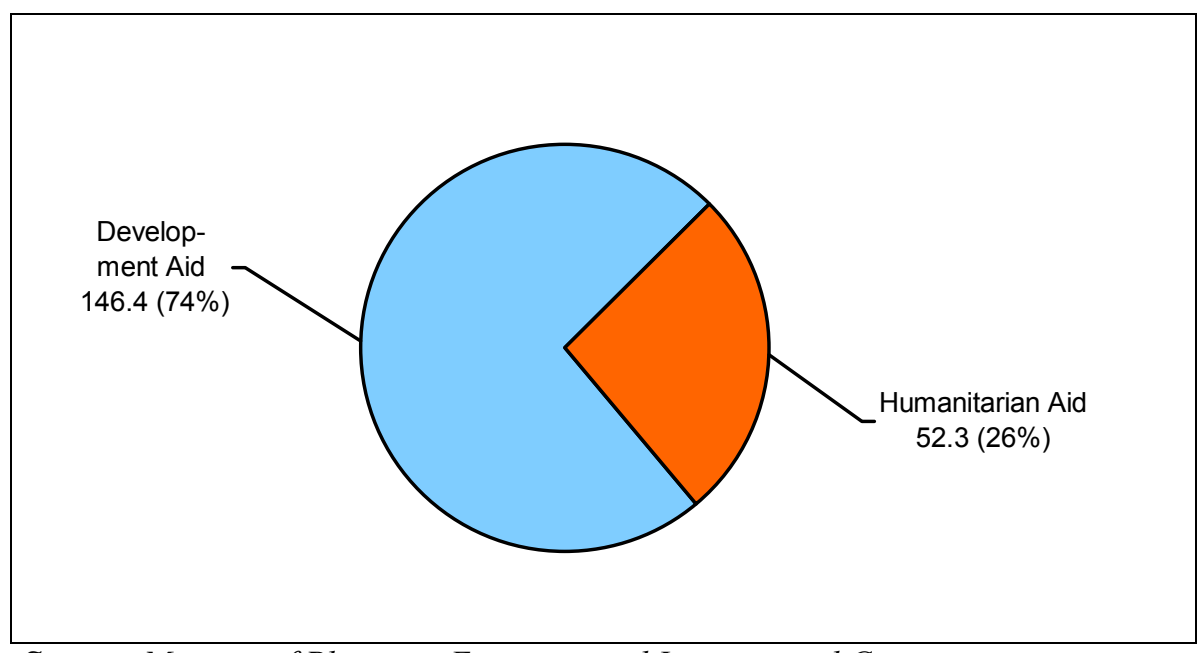

Source: Ministry of Planning, Economy, and International Corporation 


\section{Chart 3: Distribution of expenditures by pillar in 2008 (in percent)}

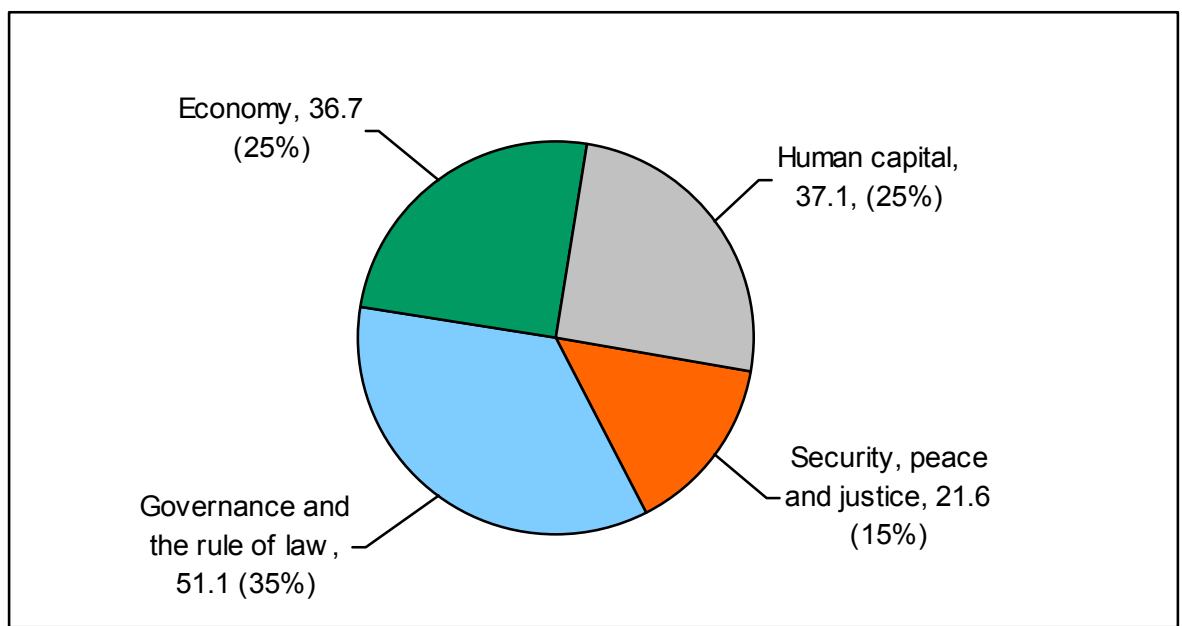

Source: Ministry of Planning, Economy, and International Corporation

Charts 4, 5 and 6 below show that compared to the various PRSP pillars, humanitarian aid receives the largest share, in terms of commitments signed, payments received, and expenditures made.

\section{Chart 4: Commitments signed in 2008 (in US\$ million)}

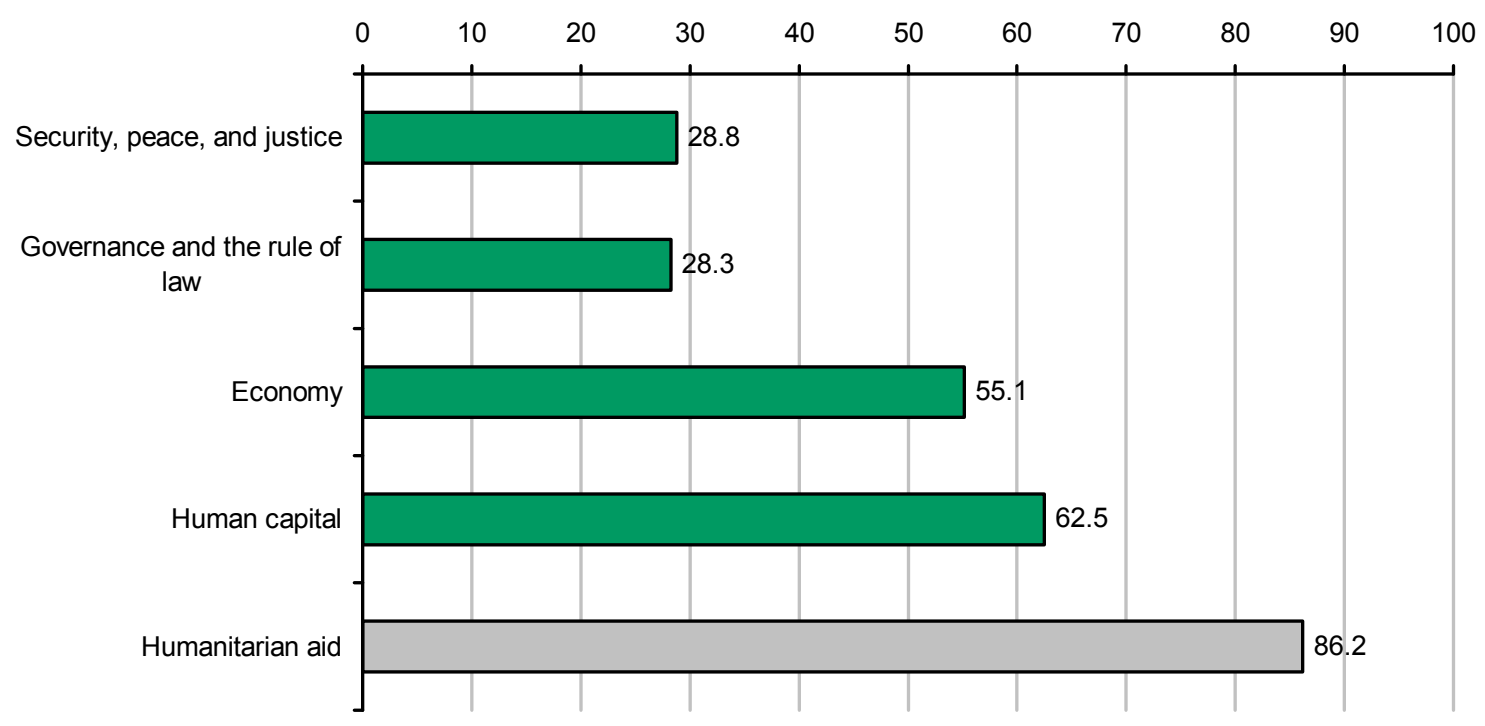

Source: Ministry of Planning, Economy, and International Cooperation 
Chart 5: Payments received in 2008 (in US\$ million)

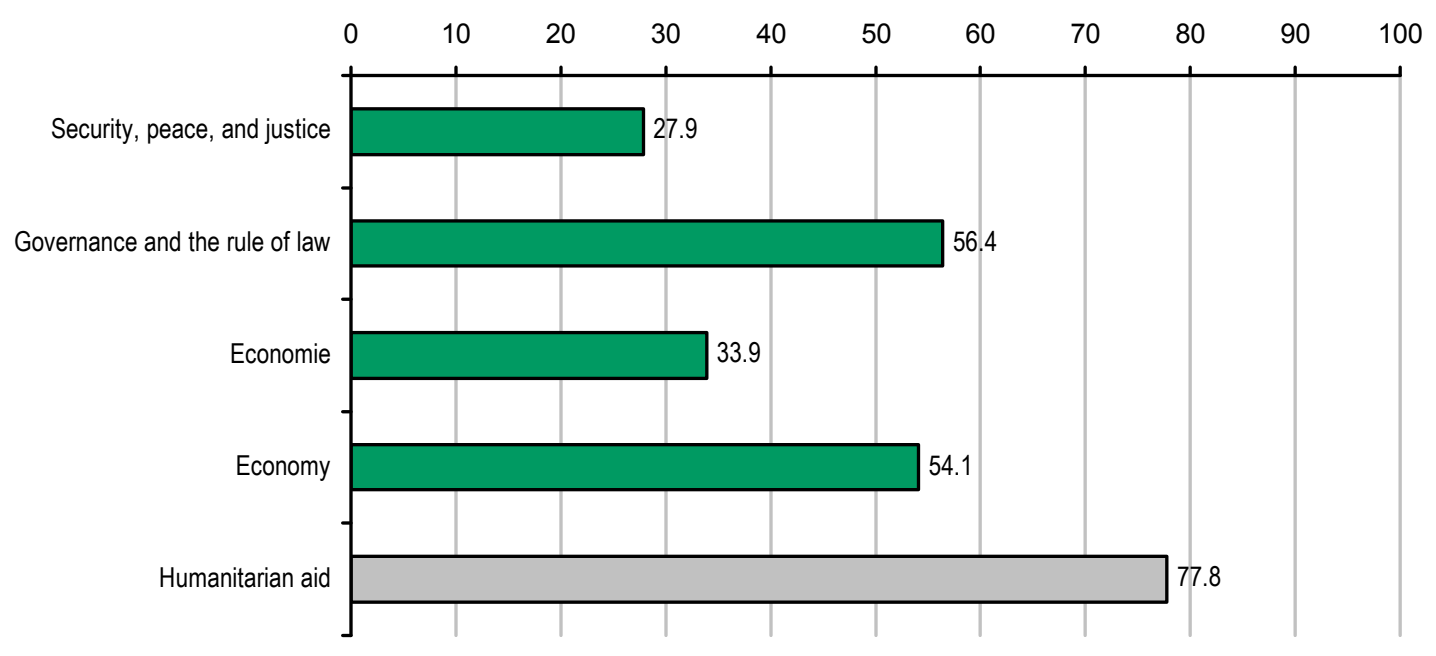

Source: Ministry of Planning, Economy, and International Cooperation

\section{Chart 6: Expenditures made in 2008 (US\$ million)}

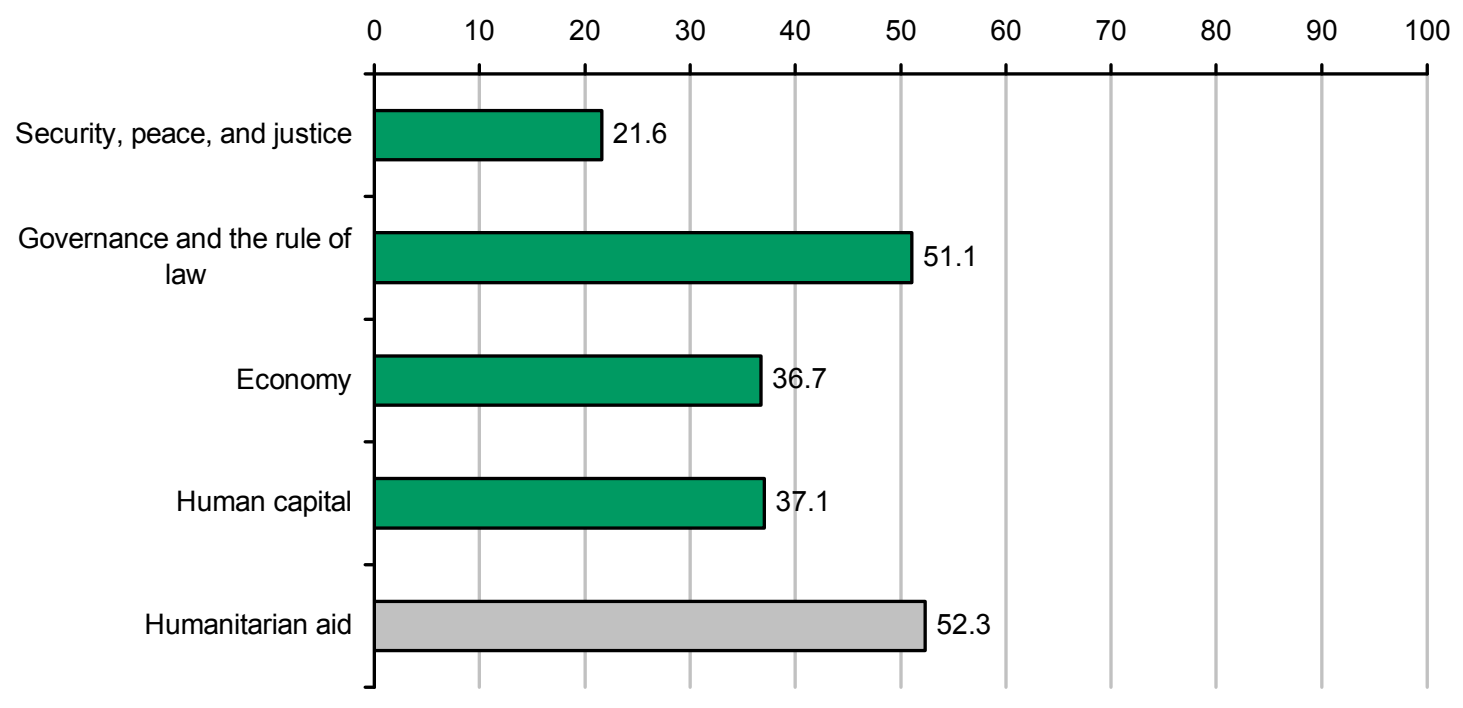

Source: Ministry of Planning, Economy, and International Cooperation

\section{Assessment of PRSP implementation}

\subsection{Restore security, consolidate peace, and prevent conflict}

The security and peace situation in the CAR is very fragile, undermined by the weakness and the high degree of politicization of the security forces, a defective judiciary system, and poor governance. Without a modicum of peace and security, and some assurance against the outbreak of new conflicts, it is utopian to think that the programs and projects included in the poverty reduction strategy can be implemented satisfactorily. Aware of this situation, the government has 
made it the first pillar of its PRSP to restore security, consolidate peace, and prevent conflict. The four areas of focus selected for implementing this pillar are:

- Strengthening the human and material capacities of the FDS (defense and security forces).

- Reform, restructuring, territorial reorganization and coordinated, participatory transformation of the FDS, including preparation of a white paper.

- Sub-regional security, and efforts to contain the proliferation of small arms and light weapons.

- Education, development and restoring trust between the public and the FDS.

\subsubsection{Strengthening the human and material capacities of the FDS and the justice system}

During the period under review, the government has taken a series of measures to strengthen the FDS, including:

- Reinforced staffing for the gendarmerie, where 196 new agents ("student gendarmes") are now being trained.

- Establishment of a school for officers and sub-officers: 60 students have been admitted in the first cohort and are undergoing training.

- Continuation training of 2 to 8 weeks for members of the FDS: 960 agents have received training in civics, ethics and international humanitarian law, financed by the government.

- Provision of uniforms and various materials to the police force: 300 police officers have been outfitted by the French technical cooperation authorities.

- A national commission has been established to draw up a legislative framework for the municipal police.

- Introduction of a refresher training system for national police agents in partnership with BONUCA.

- 12 outreach campaigns for people in areas where garrisons are to be reestablished.

- Lobbying for funds (US\$10 million raised through the Peace Consolidation Fund).

- Prime ministerial order instituting the framework of action for sectoral implementation and follow-up.

- The military programming law is being finalized.

- A committee has been established to publicize international humanitarian law (IHL).

- Guidelines are under discussion for preparation of the national defense white paper.

In the justice area, the following efforts have been supported by UNDP, the EU and the World Bank:

- The high courts of Bozoum, Bossangoa, Kaga Bandoro and Sibut have been equipped with vehicles, office furnishings and computers.

- Two courthouses have been built at Bossangoa and Kaga Bandoro, and those of Bozoum and Sibut have been rehabilitated.

- 22 regional courts are operational.

- Continuation training has been provided for magistrates at ERSUMA in Benin.

- 42 magistrates and 5 court clerks have been trained at ENAM in Bangui.

- Other court officers have been trained at Ndélé and Birao by MINURCAT. 
- Judges of the Court of Accounts have been sent for professional development in Paris and Cotonou.

- The Court of Accounts budget has been increased from US\$10,000 (CFAF 5 million) in 2008 to US\$40,000 (CFAF 20 million) in 2009.

These measures are targeted at the police, the army and the justice system, which are the key links in the chain responsible for preserving law and order and the observance of human rights. These measures are expected to improve the behavior of the FDS and prison guards, and thereby help create a climate of confidence that will reassure the public and reduce the number of repeat offenders in detention.

\subsubsection{Reform, restructuring, territorial reorganization and coordinated, participatory transformation of the FDS}

The purpose of this initiative is to establish a secure environment that will foster development in a context that is democratic, transparent, equitable and respectful of the rule of law, by strengthening the management of security institutions and establishing FDS that are competent, professional, and respectful of the country's laws.

The most important activity in 2008 was the national seminar on reforming the security sector, held in April in Bangui. The conclusions from that seminar will be used to address the challenges identified with respect to this pillar. In preparation for the seminar, 11 members of the preparatory committee received training with UNDP support. The conclusions from the seminar were submitted to the CAR's technical and financial partners at a meeting in Yaoundé, May 25-27, 2008. The final report was officially submitted to the authorities and published on August 23 , 2008. Since that time, the government has been working to implement the various conclusions and recommendations for addressing the challenges identified.

An ad hoc committee has been set up to review all laws and regulations relating to the FDS. The upgrading of the Central African Police has been enshrined in Law 08.016 of May 20, 2008, the Special Police Statute.

\subsubsection{Sub-regional security, and efforts to contain the proliferation of small arms and light weapons}

The unfortunate security situation in the CAR is attributable in part to the proliferation of small arms and light weapons resulting from recurrent conflicts in neighboring countries, especially Chad, Democratic Congo, and Sudan. The government intends therefore to work with its neighbors at the sub-regional level and to pursue cross-border initiatives to consolidate the peace.

The process of reducing and controlling small arms and light weapons saw the collection of 921 weapons by the PRAC and MINURCAT. Under the PRAC, 4,590 former combatants have been demobilized and socially reintegrated; 429 weapons collected were incinerated on August 23, 2008. The government has launched a series of steps that it will be pursuing with the aid of its partners. In particular, it has enormous and pressing needs for surveillance of the territory in general and of its borders in particular. 
The admission of the CAR on June 12, 2008 into the action plan of the United Nations Peace Building Commission marks the international community's recognition of the efforts the government has already, and of the challenges that must be overcome to achieve the objective of consolidating peace in what is a very unstable region.

\subsubsection{Education, development and restoring trust in the FDS}

The lack of professionalism in the FDS and the absence of trust between the security forces and the people have been identified as the main obstacles to reconciliation and the restoration of peace and a sustainable climate of security. The government intends to pursue actions already underway to protect the public and to develop a police force that is focused on prevention and that can work with the local community.

To reestablish and strengthen trust between the public and the FDS, 12 outreach sessions for local people have been organized, funded by the government, in areas where garrisons are to be reestablished and the FDS are to be redeployed. These sessions include CIMIC (Civilian-Military Cooperation), sporting and cultural activities. At the initiative of the Ministry of Defense, several dismantling and control missions have been conducted throughout the country, and 25 illegal roadblocks have been removed.

In addition, training has been provided to make village and neighborhood chiefs in the cities of

Bossangoa, Bozoum, Kaga Bandoro and Sibut aware of the limits of their powers, and discussion sessions have been held in the schools between the police and national NGOs.

These activities have created a more relaxed environment that now needs to be rapidly consolidated by seeking consensus on the country's major problems. This is the desire of most Central Africans, who have focused their sights on implementing the conclusions from the Inclusive Political Dialogue.

Several steps have been taken to lay the groundwork for this dialogue:

- A peace accord between the Central African Government and the Front Démocratique du Peuple Centrafricain (FDPC) was signed at Syrta in Libya on February 1, 2007.

- A peace accord was signed with the Union des Forces Démocratiques pour le Rassemblement (UFDR) on April 1, 2007, at Birao, the capital of the Vakaga.

- A peace accord was signed with the Armée Populaire pour la Restauration de la Démocratie (APRD) on May 9, 2008 at Libreville, Gabon, mediated by the President, El Hadj Omar Bongo Ondimba.

- A Global Accord was signed on June 21, 2008 at Libreville, mediated by the Gabonese President.

- Three amnesty laws were voted on September 29, 2008 by the National Assembly and were promulgated by the Head of State on October 13, 2008.

The Inclusive Political Dialogue (IPD) was held in Bangui from December 8 to 20, 2008, involving all Central African political protagonists. It produced frank discussion and a consensus on the country's major problems, and strong recommendations were adopted in the following areas: (i) politics and governance, (ii) security and armed groups, and (iii) socioeconomic 
development. Of particular importance was the adoption of the principle of establishing a new government that would run the affairs of state by consensus. Among the first fruits of the IPD recommendations was the establishment in January 2009 of a government based on broad consensus, and a census of former combatants as part of the DDR program.

\begin{tabular}{|c|c|}
\hline Box 4 : Monitoring reform activities in the security sector \\
\hline \multicolumn{2}{|c|}{ Activities/measures } \\
\hline \multicolumn{2}{|c|}{ FACA and Gendarmerie } \\
\hline
\end{tabular}

- Retirement of personnel at the age limit and multiethnic recruitment, finalization of an agreement with the donor to help the government pay salary arrears.

- Create an ad hoc committee to revise and update all laws and regulations

Prepare and adopt a military programming budget law

- Develop a program of civic and ethics instruction (International Humanitarian Law) for the Army

- Hold monthly press briefings on the status of government reform activities

- Conduct local outreach activities in garrison reestablishment zones, including CIMIC, sporting and cultural events.

- Review the mechanism for dismantling illegal roadblocks

\section{National Police}

- Adopt a special statute for the police

- Hold periodic meetings between the press and the FDS

- Equip the FDS with uniforms and materials
- Personnel at the age limit have been retired, and the agreement with the donor for helping the government pay salary arrears has being finalized.

- A national recruitment competition is being supervised by the local authorities and an external observer.

- A committee to review and update laws and regulations is now operating

- The Financial Expenditures Program Law is now being finalized

- 960 FDS members have been trained

- Not achieved

- 12 outreach campaigns have been organized.

- "Open door" days have been instituted

- 25 illegal roadblocks have been dismantled
- The special police statute has been promulgated (Law $\mathrm{n}^{\circ} 08.016$ of May 20, 2008)

- Awareness campaigns have been organized for political, administrative and judicial authorities

- 300 police kits supplied by the French technical cooperation authorities. 


\begin{tabular}{|c|c|}
\hline \multicolumn{2}{|r|}{ Justice } \\
\hline $\begin{array}{l}\text { - Train and assign wardens and guards to } \\
\text { women's prisons } \\
\text { - Implement the RSS (security reform) } \\
\text { project }\end{array}$ & $\begin{array}{l}\text { - } 4 \text { wardens and } 12 \text { guards have been trained } \\
\text { for women's prisons } \\
\text { - The Judicial Security Support Program } \\
\text { (PRASEJ) is underway }\end{array}$ \\
\hline \multicolumn{2}{|r|}{ Water and forests } \\
\hline $\begin{array}{l}\text { - } \\
\text { - Community awareness campaign and a } \\
\text { permanent system of public information } \\
\text { on forestry sector activities }\end{array}$ & $\begin{array}{l}\text { - The forestry code has been promulgated } \\
\text { (Law } 08.022 \text { of October 17, 2008) } \\
\text { - Social communicators are working under } \\
\text { contract in the PEA (forest operation and } \\
\text { management permit) units to make local } \\
\text { people aware of how forestry taxes are being } \\
\text { distributed to the communes by the } \\
\text { committee responsible for vetting the } \\
\text { employment program, and they are hosting } \\
\text { awareness programs over local radio. This } \\
\text { campaign is being repeated at the } \\
\text { departmental level by the outreach and } \\
\text { awareness service which sponsors radio and } \\
\text { TV broadcasts and publishes articles in the } \\
\text { press, under the "Pendere Gbako" program } \\
\text { initiated by the Ministry of Water and } \\
\text { Forests, Hunting, Fishing and the } \\
\text { Environment. An economic observatory has } \\
\text { been created for this purpose, embracing } \\
\text { several ministerial departments (Ministry of } \\
\text { Planning, the Ministry of Finance, } \\
\text { CTP/PAS). The partners have recommended } \\
\text { that information on financial flows to the } \\
\text { communities should be posted in the } \\
\text { communes. }\end{array}$ \\
\hline
\end{tabular}

\subsection{Promote good governance and the rule of law}

Restoring peace and security is a prerequisite for any development activity. Good governance and restoration of the rule of law are thus the second priority, and they constitute the second pillar of the PRSP. This pillar is expected to restore private sector confidence and to boost investment. It is also intended to promote democracy and human rights, to combat corruption, to improve fiscal management, etc. In time, the government hopes to use the outcomes of this pillar to increase public investment in infrastructure, by devoting fewer resources to defense, armaments and security. The two key themes of this pillar are the promotion of good governance and of gender equality and equity. 


\subsubsection{Promotion of good governance}

Promotion of a democratic culture. The plan to promote a democratic culture embraces four activities: (i) introduction of a support plan for the National Assembly, the Constitutional Court, the High Council of Communication, and the National Dialogue Follow-Up Committee (CDADN); (ii) reorganization and capacity building for civil society; (iii) development of media capacities to communicate a democratic culture; and (iv) promoting a permanent political and social dialogue. All of these activities have now begun.

Measures have been taken to support public institutions and civil society and to strengthen their capacities. Among other moves, the Media Observatory has been established and outfitted, a department of information and communication sciences is being created at the University of Bangui, community radio stations are being set up in rural areas (Paoua, Kaga-Bandoro, Birao) and the broadcasting center at Bimbo is being expanded. In connection with the Inclusive Political Dialogue, a preparatory committee has recorded signature of accords with four rebel movements, a general amnesty has been issued for all involved, and a political conference was held in December 2008. Several dialogues have also been launched with the labor unions. UNESCO and China have provided funding for these activities in the order of US\$1.6 million, or CFAF 790,706,000.

Promoting human rights. 10 officers have been trained for the High Commission for Human Rights. To improve public administration and make it more effective, the general statute of the civil service is being revised and organizational audits of seven pilot ministries are being finalized.

Strengthening the rule of law. Three activities were planned: (i) revision and update of legislation, digitization of the Official Gazette, and membership in the Global Legal Information Network (GLIN); (ii) construction of courthouses and detention centers throughout the country; and (iii) reinforcing the capacities of justice officials and auxiliary staff.

Improving fiscal management. Fiscal reforms are designed to address the constraints inherent in the structural weakness of public revenues and investment, inadequate rules and procedures for managing the public finances, and the low level of computerization. Seven activities were planned: (i) preparation and adoption of new budgetary and accounting classifications; (ii) preparation and introduction of guidelines and manuals of expenditure procedures and control; (iii) update of the tax base and taxation regimes; (iv) strengthening the customs clearing house at Douala and establishing those for Pointe-Noire and Garoua; (v) upgrading the customs facilities at Bamboula and Béloko; (vi) introducing an integrated fiscal management system (SIGFIP); and (vii) establishing a transparent framework for government procurement.

These reforms will make it possible to achieve the program objectives supported by the Poverty Reduction and Growth Facility (PRGF) under the "prudent" (trend) scenario of the PRSP. The principal objectives for fiscal management are to enhance State revenues by 0.7 percentage points to 10.9 percent of GDP in 2008, and to bring public investment to 4.6 percent of GDP in 2008 .

In addition, measures have been taken to comply with the treasury audit recommendations (AFRITAC CENTER mission), with the following results: 
- The legal framework for fiscal management has been strengthened with adoption and signature of Organic Budget Law 06.013 of June 3, 2006, the signature of several decrees including those governing the organization and functioning of the Ministry of Finance and those establishing general accounting rules for government and regulating government expenditure procedures.

- Budget reconciliation law: accounting records for 2007 and 2008 have been updated and recorded, and the resulting management accounts will be available in June 2009.

- Budgeting: the initial draft of the Medium-Term Expenditure Framework (MTEF) was revised following the workshops held in March and April 2008; the technical monitoring committee was established in September 2008 by inter-ministerial decree 618, and is now operational.

- Revenue enhancement: the General Directorate of Taxation is now using the SYSTEMIF software to improve its taxpayer records; the General Directorate of Customs is using the SYDONIA software; tax compliance has been improved and tax audits increased; human resources at the Douala customs office have been reinforced, and a formula for quarterly determination of oil prices at the pump has been introduced.

- Expenditure control: a simplified procedure for administrative and financial management of government civilian and military personnel has been instituted by decree; new budget and accounting classifications have been prepared and harmonized; the SYSGAD software has been installed in the debt management office; an interagency committee has been created to examine requests for tax waivers and exemptions; cash management has been improved with the creation of a liquidity monitoring committee; a plan has been adopted to clear the government's domestic arrears; and the treasury has stopped issuing checks not covered by cash balances. The GESCO software has been installed in the General Directorate of Budget and Treasury for tracking expenditures throughout the budget chain.

- Transparency: the treasury's asset accounts with commercial banks have been audited, and the report is available; the decree restricting the opening and management of State bank accounts is being enforced as an important step to reestablishing a single treasury account (CUT); Law 08.017 of June 6, 2008 was adopted, establishing the government procurement code and the delegation of public services; Decree 08.321 of September 5, 2008 governs the organization and operation of the General Directorate of Procurement; and Decree 08.335 of September 20, 2008 governs the organization and functioning of the procurement regulatory authority.

- Customs: training has been provided for customs officers; codes governing procedures for the movement of merchandise and surveillance personnel have been prepared; the customs office at Douala was shut down following complaints against the contractual operator (UNITECH Benin) and the exemptions committee has been made operational. 


\begin{abstract}
\begin{tabular}{|l} 
Box 5: Follow-up to priority action on \\
Priority actions \\
(i) Apply the provisions of articles 44
\end{tabular} and 75 of the Constitution governing the declaration and disclosure of assets of the Prime Minister, members of the government, the Constitutional Court, and managers of public enterprises and revenue-collecting agencies [régies financières].
\end{abstract}

(ii) prepare the budget using the new classification and submit it to parliament.

(iii) implement a new expenditure tracking system from commitment (engagement) to payment order (ordonnancement) in the budget directorate (using the new classification).

(iv) implement the simplified government personnel management system .

(v) have parliament adopt a new procurement code and begin using it.

(vi) combat corruption :

- create a National Anticorruption Committee (CNLC)

- prepare a national anticorruption strategy

- declare a national anticorruption day

(vii) combat fraud:

- Institute an antifraud committee

- make the "Financial Hub" (Pôle financier) operational
Results

(i) 21 members of the government and 12 General Directors of public enterprises and revenuecollecting agencies have declared their assets to the Clerk of the Constitutional Court and to the Office of the Inspector General.

(ii) the 2008 budget law has been promulgated, using the new classification.

(iii) Decree $n^{\circ} 08.146$ of April 11, 2008, regulating public expenditure procedures, defines the tasks assigned to the responsible staff.

(iv) a simplified procedure for the administrative and financial management of government personnel was officially launched by the Prime Minister on May 29, 2008.

(v) The Procurement Code has been promulgated (Law $\mathrm{n}^{\circ} 08.017$ of June 6, 2008). The General Directorate of Procurement and the public procurement regulatory agency have been created, and Decree $\mathrm{n}^{\circ} 08.382$ governs the appointment of their staff; a decree governing procurement officers in key ministries is expected shortly.

- The National Anticorruption Committee is operational (Decree $n^{\circ} 08.133$ of March 31, 2008);

- The national strategy (Draft 0) is available

- The first National Anticorruption Day was held on December 9, 2008.

- The Antifraud Committee is in place

Legal proceedings are underway against 50 managers of revenue-collecting agencies. 
- Corruption: Decree 08.133 of March 31, 2008 created the National Anti-Corruption Committee (CNLC), which has been operational since July 31, 2008; a national expert was recruited in July 2008 under the ARCAD program, with UNDP financing, to provide standing support to the CNLC; work has begun on preparing a national anticorruption strategy; an inter-ministerial committee was established in June 2008 to consider ways of combating corruption in the revenue-collecting agencies, as a result of which several taxation and treasury officials have been investigated and arrested.

- Data management: a decree of the Minister of Finance and Budget created a user service bureau within the Office of the General Inspector of Finances, dealing with debt questions; a plan for clearing domestic arrears has been implemented; the SYSGAD management software has been acquired; a database for the public and State-guaranteed debt has been updated with support from UNCTAD. In December 2008, the updated value of domestic debt service (including debt to the IMF) stood at US\$36 million or CFAF 18 billion, of which US\$28.8 million (CFAF 14.3 billion) is currently up-to-date. Settlements to date have totaled US\$15 million (CFAF 7.5 billion), including US\$2.2 million (CFAF 1.1 billion) to the IMF, US\$1.8 million (CFAF 0.9 billion) to the BEAC, and US\$11 million (CFAF 5.5 billion) to banks and to endorsements and loans. Confirmed government arrears to public enterprises from 2005 to 2007 stand at US\$827,531 or CFAF 413,765,539 (SODECA), US\$105,925 or CFAF 52,962,790 (ENERCA) and US\$387,165 or CFAF 193,582,664 (SOCATEL), against invoices of US\$1.9 million (CFAF 962,023,352), US\$446,354 (CFAF 223,177,414) and US\$2.8 million (CFAF 1,395,431,679), respectively.

\section{Revitalizing the process of decentralizing and reorganizing the territorial administration.} Activities to revitalize the decentralization process have included: (i) strengthening the institutions responsible for decentralization and boosting the capacities of the local and administrative authorities; (ii) basic studies to gain a better understanding of the conditions that make decentralization feasible; (iii) public consultation sessions (états généraux) on decentralization; (iv) preparation of basic legislation governing the reform; (v) organization of municipal elections; and (vi) the creation of secondary "development hubs".

Activities to date have resulted in the overhaul and outfitting of the High Commission for Decentralization, the equipping of three local radio stations (Nola, Berbérati, Bambari), arrangements for training 100 mayors, the fielding of missions to study and learn from foreign experience with decentralization, programming of activities of the inter-ministerial committee of experts to examine basic legislation, and organization of municipal elections. The UNDP has provided nearly US\$286,000 (CFAF 143 million) for these activities.

\subsubsection{Create a favorable business environment}

The government is determined to improve the business climate, and to this end is taking action on the three aspects of governance: political, administrative and economic. It has focused on securing the rule of law, a properly functioning civil service, a sharp reduction in corruption, improved fiscal management, and pursuing decentralization so as to unleash local energies and foster participatory development based on local resources. These efforts should bring significant changes, internally and externally, to the country's development process. 
Six specific activities were planned to create this favorable business environment: (i) preparing industrial and trade policy documents and a private sector development strategy; (ii) strengthening legal security for businesses; (iii) creating a "one-stop shop" for handling business formalities; (iv) developing public-private partnership; (v) restructuring the Chamber of Commerce and making it operational; and (vi) reviving structures of promotion and support for the private sector.

The CAR's trade policy paper has been prepared and validated, a study of commercial integration has been conducted, the commercial code has been prepared and harmonized with regional and international codes, the investment charter is being revised with EU funding, and the "one-stop shop" for business formalities (GUFE) is now operating in the city of Bangui. Funds raised for these activities amount to $€ 1.245$ million, or US\$1.63 million.

The "one-stop shop" for businesses was created by Decree 07.371 of December 17, 2007. It has already produced some very encouraging results: the time needed to create an enterprise has been reduced from an average of $1-4$ months to an average of $1-2$ weeks, and this will place the CAR in a better position to attract foreign and domestic investors and economic operators. In 2008, the GUFE processed 500 applications from enterprises registered in the city of Bangui alone - as many as for the entire country in 2007 (269). This performance should have an impact on the level of investment and job creation, helping thereby to improve living conditions.

During the course of 2008, the Action Plan for the Integrated Framework was made operational. Of the US\$1 million raised from the WTO, US\$630,000 has been used with the following results:

- 1 project management unit created and operational.

- 27 economic operators trained.

- 3,000 tons of sesame harvested and sold.

- 350 businesspeople in seven regions of the CAR trained and made aware of the importance of commercial information.

- 900 voters and 50 business candidates registered for consular elections.

- Roundtable on the trade sector held on February 19, 2009, which enlisted the support of new bilateral partners (Algeria, Turkey, South Africa, India) and multilateral ones (BDEAC, UNIDO, ECA, ADB, WIPO, JEICP/ILEAP - International Lawyers and Economists against Poverty).

\subsubsection{Promoting gender equality and equity}

The government is aware that women are more exposed to poverty because of the many disparities they face in terms of access to basic social services, to credit, to the factors of production, to urban management, etc.

The government is therefore committed to strengthening and enforcing legal, judicial and institutional provisions relating to women's participation. Three activities were planned for 2008 to this end: (i) capacity building for female leaders; (ii) strengthening the legal, judicial and institutional framework relating to women's participation; and (iii) enlisting women in conflict resolution, pursuant to Resolution 1325. 
The second of these three activities has been fully realized, while the first and third are underway. They have resulted in:

- The holding of sessions to publicize the two laws relating to reproductive health and protection of women against violence: the sessions were targeted at legal professionals, judicial police officers (OPJ), health professionals, social workers, public and private media professionals, youth and women's organizations and associations.

- 20 women have been recruited for training as auxiliary police officers and gendarmes over a period of six months, and associations and groups of female victims of violence have received support for income generating activities.

These activities were supported by a grant of US\$180,000 (CFAF 90 million) from the Finnish fund for peace building.

Because gender equality and equity are so important for governance, the government intends to overcome the various constraints that held back the activities programmed for 2008, in particular the shortage and weakness of human resources, delays in delivering program support (disbursements, materials etc.), the lack of funding for some operations, social and political resistance, the inadequate flow of information and communication, organizational problems in

mobilizing resources, failure to enforce regulations, social and cultural obstacles (the lack of collective thinking and interests), and shifting points of focus in the PRSP.

The following factors should work in favor of these efforts: there is strong political will and determination to implement the PRSP, the people have great aspirations for peace and reconciliation, and civil society is insisting on participatory involvement in economic and democratic governance. This setting lends added strength to the structures for monitoring the activities of the sectoral committee concerned, and the committee has already identified its needs in terms of support missions and assistance in conducting feasibility studies for the various projects and in preparing for the sectoral roundtable.

\subsection{Rebuilding and diversifying the economy}

The government is looking to strong, sustainable and pro-poor growth to reverse the perverse effects of poverty at the national and regional levels. It therefore intends to pursue a prudent set of macroeconomic policies in order to achieve a lasting recovery, in accordance with the guidelines of the programs concluded with the Bretton Woods institutions. With the gradual restoration of security, the reconstruction and diversification of the economy will focus on the development of production, especially in rural areas where most of the poor are concentrated. Programs and projects are targeted broadly at the following areas:

- Modernizing agriculture and developing livestock production.

- Making better use of forest resources.

- Developing the mining sector.

- Promoting cultural industries and arts.

- Promoting tourism.

- Developing transport infrastructure. 
- Developing energy resources.

- Developing telecommunications and ICT.

- Developing basic public services.

\subsubsection{Modernizing agriculture and livestock raising}

The rural sector holds the potential for great leverage in fighting poverty, because of its weight in the economy and because of the geographic distribution of poverty (72 percent of poor people live in the countryside). The government intends to promote and modernize agriculture and livestock raising, focusing on the following key aspects: (i) assisting farmers, (ii) strengthening rural institutions, (iii) intensifying and diversifying output, (iv) breaking down rural isolation, and (v) establishing infrastructure in support of production, storage, processing and marketing.

In its efforts to assist farmers, the government will pursue measures that were first introduced in the initial post-conflict years: (i) providing the hardest hit population groups with the assistance they need to revive their activities; (ii) establishing linkages between emergency responses and efforts to revive the agricultural sector; (iii) harmonizing its interventions around national priorities and the PRSP in order to lay the basis for providing services to producers and reviving agriculture on a sustainable basis.

The FAO supported these interventions in the initial post-conflict years with a total of US $\$ 9.42$ million (about CFAF 3.9 billion). Nearly US\$8.12 million (around CFAF 3.37 billion) was reserved for humanitarian assistance through the supply of farming inputs to the poorest families and those most affected by the political and military conflicts, so that they could resume food production and revive farming and the rural economy. Of this amount, some US\$5.4 million (CFAF 2.7 billion) was earmarked for crops and slightly over US\$1.31 million (CFAF 655 million) for livestock production and reinforcing the capacities of partner institutions (NGOs), including government services (ICRA [Institut centrafricain de la recherche agronomique], ACDA). In addition, steps were taken to clear producers' arrears in the amount of US\$4.7 million (CFAF 2,333,451,000), of which US\$4.6 million (CFAF 2.3 billion) was provided by the European Union and US $\$ 100,000$ (CFAF 33,451,000) by the CAR government in 2007, with a view to reviving cash crops, and more particularly cotton, which is widely grown in the heavily populated prefectures of Ouham, Ouham-Pendé, Ouaka, Kémo and Nana-Grébizi (which account for 34 percent of the national population). Programs and projects implemented in 2008 were targeted primarily at moving the country toward the Millennium Development Goals, especially those relating to food security and the reduction of extreme poverty, and sustainable and equitable management of natural resources, in particular improved governance in the forestry sector.

To strengthen agricultural institutions, the government created the Agricultural and Livestock Development Fund (FDAP, Law 07.015 of June 19, 2007) and the National Agriculture and Livestock Materials Office (ONMAP, Law 07.016 of 19 June 2007). In order to harmonize the various partners' interventions and create synergy with United Nations agencies, NGOs and other development partners, and to lay the basis for sustainable development, the government has been working with FAO support to prepare a National Medium-Term Priorities Framework (NMTPF). This programming framework will have to be articulated with the PRSP 2008-2010, the UNDAF 
(United Nations Development Assistance Framework) 2007-2011, and other related strategy documents.

Institutional capacity building began in 2008 with the establishment of thematic working groups to propose priority reforms in agriculture and the rural economy. The recommendations from the Etats Généraux for Rural Development and the results of the Priority Reforms Committee's work will make the poverty reduction and growth strategy more efficient by updating strategies for rural development and food security.

Despite the importance that donors have given to emergency assistance during this post-conflict phase, the FAO considers that its Regular Program should receive more attention. That portfolio focuses on developing pilot projects and strengthening the capacities of national institutions by preparing strategy documents and action plans as well as specific or thematic studies of different economic activities. For example, there is a pilot project for post-conflict economic reintegration through the revival of small animal husbandry (poultry, cane rats [aulacodes], small ruminants).

Five agricultural intensification and diversification projects have been launched in collaboration with the FAO, with financing from partners. In the area of crop production, inputs and small implements have been supplied to 8,500 vulnerable farming families as part of the initiative to counter the food crisis and rising food prices by reviving output in the prefectures of Ombella M'Poko, Lobaye, Kémo and Bangui. Some 16,000 horticultural kits were also distributed to families at risk because of HIV/AIDS, 5,000 animal traction teams [chaines de traction animale] have been supplied through the food crisis response fund, 224 ha of seed multiplication plots have been established in five "development hubs" (Bouar, Kaga Bandoro, Sibut, Bambari and Bossangoa), and a strategic stockpile of food crop seeds and farm implements has been constituted for 30,000 families.

On the livestock front, (i) 104 pilot production units have been established as the first step in a much broader investment program for reviving small livestock raising, and (ii) financing has been provided for units in disaster areas that will produce eggs, day-old chicks, poultry, Guinea fowl, swine, goats and small ruminants. The newly-created Agriculture and Livestock Development Fund (FDAP) and the National Agriculture and Livestock Materials Office (ONMAP) represent the most important steps for reviving the sector. These actions, taken together, should spark the revival of agricultural and livestock output and the recovery of exports.

\subsubsection{Making better use of forest resources}

The government's aim here is to enhance the transparency of forest and wildlife resource management, while creating a more attractive business environment. This calls for establishing a sectoral policy for the sustainable management of forest resources that will: (i) rationalize their potential and their exploitation, (ii) protect biodiversity, (iii) combat desertification and its damaging effects, and (iv) increase the sector's contribution to growth and job creation.

The new forestry code was prepared through a participatory approach that involved all stakeholders, including the development partners, and was promulgated by the Head of State on October 17, 2008. 
Decrees $\mathrm{n}^{\circ} 003 / \mathrm{MEFCPE} / \mathrm{DIRCAB} / \mathrm{DGEFP}$ of January 22, 2008 and $n^{\circ} 026 / \mathrm{MEFCPE} / \mathrm{DIRCAB} / \mathrm{DGSADRI}$ of July 23, 2008 appointed border control inspectors and created mobile "forestry and wildlife" intervention and verification brigades. Their main purpose is to control all movements of lumber leaving the national territory, to secure forestry and wildlife revenues, and to strengthen monitoring and control capacities in the forest and wildlife sectors.

The forest industry Observatory, created within the Ministry of Water, Forests, Hunting, Fishing and Environment by Decree $n^{\circ}$ 027/MEFCPE/DIRCAB/CMEFCP of July 24, 2008, represents an economic intelligence gathering tool that will support decision-making and supply reliable and relevant economic information on the industry.

Forestry and wildlife revenues will now be deposited in a bank account opened in the Central Bank in the name of the communes. These revenues are supervised by a technical committee comprising representatives of the ministries concerned (Interior, Finance and Budget, Water and Forests), intended to institute local management of those funds. The principal task of the technical committee is to validate the employment programs developed by the municipalities and to monitor projects financed from these funds as part of the campaign against rural poverty in communities in or bordering on forest lands under operating permits.

The government expects these activities to produce benefits in terms of environmental protection, increased forestry output, and improved living conditions in neighboring communities.

\subsubsection{The mining sector}

The strategy for reviving the mining sector -often regarded as the backbone of the Central African economy -calls for a significant and lasting increase in output that will sustain the economy by boosting government revenues and will help to reduce poverty among people living in mining zones. To this end, the government is planning a series of actions based on an exhaustive analysis of the sector:

- Improving and reforming the legal, institutional and fiscal framework governing the mining sector.

- Developing both small-scale (SME) operators and large mining companies.

- Raising incomes in rural areas and diversifying activities in mining zones.

- Strengthening the capacities of the institutions responsible for mining management and supervision, and involving local people.

During 2008, the government received the final report from the consultants hired to audit the mining sector as part of the work of strengthening and updating the mining code. It subsequently established an inter-ministerial committee to examine that report and send its observations back to the consultants. Once the audit report is adopted, its recommendations will be used to revise the mining code.

The government has also created an ad hoc committee to draft legislation and make preparations for establishing the Office of Geological and Mining Research. That office is to oversee the project for modernizing the country's mining management and to see to the establishment of a reliable geological database. 
Decree 08.260 of July 18, 2008 established an institutional mechanism for the Extractive Industries Transparency Initiative in the Central African Republic ("EITI-CAR"), with a view to bringing greater transparency to management of the sector. The government has thereby implemented the fourth of the five criteria required for EITI participation. This activity has received support from the ADB and UNDP.

The government has also updated legislation establishing the Bangui International Diamond Exchange, which is intended to increase mining output and improve incomes in mining zones. This revised legislation will be submitted to the Council of Ministers for adoption. A law on radioactive ores [radios minerais] has been promulgated, in order to preserve the environment, and an ad hoc committee has been established.

To strengthen capacities and make up for the delay in establishing the monitoring and evaluation committee for the sector, a "mining issues committee" (comité thématique mine) is planned to support the STP in preparing sectoral guidelines and coordinating program and project monitoring.

These organizational and capacity-building measures should allow the Uramin Areva and Aurafrique companies to begin operations as planned in 2009-2010 and will encourage smallscale miners to organize and contribute significantly to increasing production. Box 6 below summarizes progress made in reforming the mining and forestry sectors.

\begin{tabular}{|l|l|}
\hline Box 6 : Priority measures of structural reform \\
\hline \multicolumn{1}{|c|}{ Priority actions } & \multicolumn{1}{|c|}{ Achievements to date } \\
\hline $\begin{array}{l}\text { (i) publication on the } \\
\text { government's Internet site of the } \\
\text { report on mining revenues since } \\
\text { 2006, prepared by the EITI } \\
\text { administrator }\end{array}$ & $\begin{array}{l}\text { (i) The Technical Secretary, managers and members of the } \\
\text { decree. Members of the National Council and Steering } \\
\text { Committee have also been appointed by decree. A data } \\
\text { collection and reconciliation unit has been created by } \\
\text { decree. That unit will assist the administrator in collecting } \\
\text { and reconciling data before they are validated and } \\
\text { published at the EITI website. Terms of reference for } \\
\text { hiring the administrator have been finalized. This } \\
\text { information has been posted at the government website. }\end{array}$ \\
$\begin{array}{l}\text { (ii) Signature of a decree } \\
\text { establishing a standard mining } \\
\text { convention, and adoption by } \\
\text { Parliament of amendments to the } \\
\text { mining code to bring it into line } \\
\text { with the convention }\end{array}$ & $\begin{array}{l}\text { (ii) Preparatory work for revising the mining code is } \\
\text { underway. The unit responsible for revising the code and } \\
\text { preparing its application decree is in place. }\end{array}$ \\
\hline
\end{tabular}

\subsubsection{Promoting the arts and cultural heritage}

The arts and cultural heritage have been the "poor relatives" of the Central African economy, and yet they have a role to play in conveying ways of thinking, acting, producing and consuming. The government has taken them into account in the PRSP and has been pursuing action in this field 
since 2006, when the "Cultural Charter of the CAR" was promulgated, creating a framework setting out the main lines of government policy for the arts, culture and heritage sector.

There is also a document on sectoral policy guidelines and a cultural action program for economic and social development, the priority areas of which are fully consistent with the PRSP. Activities to date have focused on implementing the Reading and Cultural Life Center (CLAC) network, with funding from the OIF (Organisation Internationale de la Francophonie). Domestic counterpart funding, which was to come from the Special Capital Budget (BEC), has been held up by disbursement problems, and this has impeded actions to date. That counterpart funding is earmarked for rehabilitation and construction of 11 cultural centers.

The sectoral committee is tasked with reviving the artistic and cultural heritage as a lever for development activities of all kinds, and this should pave the way for the financing of the cultural programs included in the PRSP.

\subsubsection{Tourism development}

The CAR's tourism potential lies in the abundance and diversity of its resources, which hold great promise for ecotourism. Despite the country's many parks and reserves, the rare animal and plant species found there are not sufficiently recognized and valued. In order to create an environment conducive to the tourism and handicraft industries, the government has prepared draft legislation and regulations, including a proposed tourism investment code and a tourism code of ethics.

A feasibility study on the construction of a cultural tourism center is now available, financed by the special forestry and tourism development account (Compte d'Affectation Spéciale/Développement Forestier et Touristique, CAS/DFT) in the amount of US\$16,000 or CFAF 8 million. Two permits have been issued to private partners to open and operate a tourism and food services agency. Conventions and protocols have also been signed with private partners for renovation of the Oubangui Hotel and the Hotel du Centre, rehabilitation of a former 500room hotel, and the construction of hotels near the airport and at Kolongo.

Handicrafts. A pilot survey of handicraft institutions and activities in Bangui and cities of the interior is now under way. The Ministry of Trade has conducted a study of integrated trade, including a tourism component, and its conclusions have been submitted to the sectoral donors' roundtable.

As part of the Dzanga Sangha project, tenders have been called for management of the Doli Lodge at Bayanga. A land-use plan for the lower Oubangui hills has been prepared and should contribute to the development of local tourism. In terms of community projects, an outline of a project for the use and protection of the Alimbou forest, prepared by an association of inhabitants of that forest, has been submitted to the Ministry for review, together with some tourism promotion projects.

Training. 70 staff members from the Boali Falls hotel, the Hotel Azimut and the La Méditerranée restaurant have received training in hospitality and culinary techniques, and 20 others are now being trained under the program to launch taxidermy activities. 
Through its support for these activities, the government hopes to be able to: (i) make available documentation on Central African tourism, (ii) create a favorable environment for investment in tourism, (iii) encourage investors, particularly tour operators, to set up shop, (iv) present a more positive image of the CAR internationally, and (v) conduct marketing in favor of Central African tourism.

\subsubsection{Transportation infrastructure}

An economic analysis of the CAR's transportation infrastructure -road, river and air -is now under way, focusing on factors of production (supply, market access, fishing etc.), and on local people's access to basic social facilities such as schools, health centers and other institutions, and tools of sovereignty for territorial surveillance and control.

The government's plan for the sector is to break down the country's internal and external barriers by 2015, through a coherent framework for the management and maintenance of transportation infrastructure. The strategy focuses on three themes: (i) strengthening the institutional framework, (ii) seeking financing, and (iii) building, rehabilitating and upgrading transportation infrastructure.

With the support of its partners, the government has been reinforcing the institutional framework for the sector and its capacity to formulate and implement policy. Thanks to that support, transport regulations are now being brought into line with sub-regional and international rules. Preparations are also underway for the transport roundtable.

In particular, the statutes of the BTP (public works and civil engineering) laboratory are being revised, and its staff are being trained, with funding of US\$160,000 (CFAF 80 million); sampling and quality control materials have been acquired, for US\$98,800 (CFAF 494 million); and the National Materials Office has been equipped, at a cost of US $\$ 3$ million (CFAF 1.5 billion) by the EU.

Other actions include: (i) making the transportation information system operational; (ii) managing transportation infrastructure within the Inter-Ministerial Equipment and Transport Planning Unit; and (iii) preparations for conducting feasibility studies of programs and projects.

Road terminals have been built or rehabilitated at Bossangoa, Bangui and Berberati. The VIP lounge at Bangui Airport has been renovated by ASECNA. Rehabilitation and maintenance work has been performed, with domestic funding from the Highway Maintenance Fund (FER) and support from external partners, on five major highway segments: Berbérati-Bayanga $(232 \mathrm{~km})$, Sibut-Kaga Bandoro-Ndélé (465 km), Sibut-Bambari (200 km), Bossembélé- BossangoaBenzambé $(195 \mathrm{~km})$ and Mbaiki-Boda $(85 \mathrm{~km})$. Rural roads have been improved $(206 \mathrm{~km})$ and bridges and culverts improved or rebuilt (52).

Tenders have been called for paving the Bouar Garoua-Mboulaï Highway (154 km), with joint financing from the EU, the ADB and the World Bank. 


\subsubsection{The energy sector}

In the energy sector particular attention is being paid to electricity, where supply falls far short of demand, and to hydrocarbons, where management is very weak and where storage capacity, at $48,000 \mathrm{~m}^{3}$ per year, represents barely half of demand. Development of the energy sector has been held back by several factors: (i) the regulatory framework is inadequate, (ii) there is no energy information system, an essential decision-making tool; (iii) the performance of ENERCA has been weak; (iv) the technology currently in use is unsuitable; (v) human resources are inadequate; (vi) there is no national energy policy; (vii) investment in the sector has been low; and (viii) internal and external barriers exacerbate the country's isolation. The PRSP focuses on the following aspects: (i) further restructuring of the sector, (ii) diversification of energy sources, and (iii) improved capacity for hydrocarbons management.

In terms of restructuring the sector, the following agencies are now up and running: (i) Central African Rural Electrification Agency (ACER); (ii) Central African Electricity Regulation Agency (ARSEC); (iii) Central African Oil Products Storage Company (SOCASP); and (iv) Oil Product Price Stabilization and Regulation Agency (ASRP). In addition, a national policy document on the energy sector has been adopted, and the biofuels law has been promulgated.

To strengthen management capacities, four officials have received training in GIS (Geographic Information Systems) and in the use of computer equipment acquired with European Union support.

For strengthening production capacities, the government plans to rehabilitate the power generating facilities at Boali I and II. The following studies are also underway:

- Study of institutional arrangements for the Boali-Bangui interconnected grid.

- Feasibility study for building the dam on the Kotto River (at Kembé).

- Analytical study for promoting poor people's access to energy services at the decentralized level.

Finally, in terms of improving hydrocarbon management capacities, the Salo storage terminal has been rehabilitated.

The energy crisis that has lasted since June 2008, and that was due in part to the sharp deterioration of installations, makes it all the more urgent now to implement the actions planned for this sector. While the real impact of the crisis on current and future activities has not been thoroughly evaluated, it is certain to hit hard at the economic fabric and at basic public services such as health, and to pose a serious threat to achievement of the PRSP objectives.

\subsubsection{Telecommunications and ICT}

It is now recognized that telecommunications can speed the growth and development of countries that know how to seize the opportunities they offer. The government has accordingly created the Telecommunications Regulatory Agency, which has begun the work of clarifying the legislative and regulatory framework for the sector. 
The government's priorities here are to promote healthy competition, improve the legal and regulatory framework, and expand the basic infrastructure so as to make telecommunications, Internet, postal and financial services more widely available across the country.

\subsubsection{Basic public services}

Basic public services include water and sanitation, housing and employment, in addition to health and education. The problem of access to water and sanitation services has two aspects: they constitute a final consumption good that has a direct impact on public health, and they are used as a factor of production in agriculture and livestock raising. Housing is regarded as a primary human need, and concerns over its quality and cost raise the question of social housing that will supply decent and affordable dwellings.

The rate of access to basic water and sanitation services, as a function of locality and living environment, is an important indicator of public well-being. There are several challenges to be addressed here:

- Boosting investment to improve people's access to basic water and sanitation services.

- Improved management and coordination of activities in the sector.

- Encouraging local people to assert ownership over works and infrastructure.

- Putting facilities on a solid footing through an appropriate cost recovery mechanism.

The Water and Sanitation Regulatory Agency (ARSEA) and the National Water and Sanitation Agency have been created, and ad hoc committees are at work to make them operational. A National Action Plan for Integrated Water Management (PANGIRE) has been prepared to improve the sector's information system, to develop professional planning capacities, and to train users in the private sector and civil society.

In terms of the construction and rehabilitation of water and sanitation works, the governor's record in 2008 is as follows:

- Water: 144 boreholes drilled, 280 boreholes rehabilitated, 184 wells rehabilitated, 21 springs improved, and 15 sand filters built on an experimental basis in the prefectures of Nana-Gribizi, Kémo, Ouham, Ouham-Pendé, Haute Kotto, Basse-Kotto, BaminguiBangoran and Vakaga. These works are expected to provide drinking water for 168,150 people under the Urban Development Master Plan for Bangui and secondary towns, at a projected cost of US\$28.6 million (CFAF 14.3 billion).

- Sanitation: 1,630 improved traditional latrines, 66 ventilated pit latrines (VIPs), 4 incinerators at sanitary facilities, distribution of 15,615 hygiene kits (soap, bucket, basin, kettles).

To ensure maintenance of these facilities, 44 members of district management committees (COGES) in the health centers have been trained in the management of water and sanitation facilities, 132 local masons have been trained in family latrine construction techniques, and 28 social communicators have been trained in hygiene and sanitation. 
In an effort to provide diversified, stable and regular funding for the sector, the government has prepared terms of reference for a feasibility study to establish the National Water and Sanitation Fund. The African Development Bank is now examining the request to finance that study.

The government has paid particular attention to housing:

- It has drawn up a master plan for urban development in Bangui, extending beyond the city limits to embrace an area of some 35,000 ha.

- Draft laws and regulations for the sector are now under study.

Under the Programme de Microréalisations ("micro-projects program", PMR), supported by the European Union, training in project design and implementation has been provided for coaches and managers of Organisations Communautaires de Base ("grassroots community organizations", OCB) in four prefectures (Lobaye, Nana-Mambéré, Ouham and OmbellaM'Poko).

\subsection{Developing human capital}

The PRSP recognizes human capital as an essential element that, through its contribution to wellbeing and productivity, can create the wealth needed to combat poverty. The government is committed to boosting the human capital of the entire population, in particular women and vulnerable social groups such as persons with disabilities, victims of conflict, and orphans. The aim is to enhance their capacity to act independently and to lift themselves out of extreme poverty. The main themes of this pillar are education, health and HIV/AIDS, youth and sports, and employment.

\subsubsection{Education}

The poverty diagnosis conducted in 2003 left no doubt that the level of education is a determinant of poverty, and that households headed by persons with a good level of education are less vulnerable than those headed by persons with no schooling. This explains the importance that the government attaches to education in the PRSP, where the objective is that "all children of both sexes, wherever their place of residence, will receive a complete and high-quality elementary (Fondamental-1) education". The following actions are planned:

- Expand the availability of education.

- Create the conditions for attracting the maximum number of girls and boys.

- Increase the percentage of pupils completing primary school.

- Improve the retention rate.

- Raise awareness and mobilize all partners.

The government's education strategy aims in particular to improve educational access and quality and to reduce disparities, with the following targets for 2010:

- Elementary school enrollment ratio of 73 percent for children ages 6 to 11 years, and a reduction in the current disparity between girls and boys.

- A primary level completion rate of 74 percent. 
- A decrease in the drop-out rate to 9 percent for girls and 6 percent for boys.

- Greater mobilization of stakeholders and partners in the education system.

The main results to date appear in the context of the Education Program Support Project (PAPSE) that emerged from the RESEN study of the education system: three buildings have been renovated, a full (six-year) primary school has been built, and four schools in areas affected by conflicts have been equipped with furniture (5,590 units).

The government has also used its own funds to provide accelerated training for 450 elementary (F-1) school teachers in the regional Centres Pédagogiques (normal schools), and 832 qualified F-1 teachers have been hired. Refresher courses have been organized for education officials and parent-teachers in the prefectures of Lobaye, Kémo, Nana Grébizi and Haute Kotto. Selected schools have received 2,925 readers and 2,925 mathematics textbooks. As well, 5,680 teaching kits have been acquired for all F-1 teachers. During the school year 2007/2008, there were 790 latrines and 528 water points constructed, 577 canteens were established in 423 F-1 schools and in 54 kindergartens, serving 98,000 pupils in areas not affected by conflicts. These canteens were built by the WFP, in addition to its humanitarian work.

To improve primary school completion rates, the government, with the support of various education partners, has established a committee to consider the potential of using school buildings as preschool centers for the protection and training of young children in Nana-Grébizi and the preparation of exercise books for teachers and pupils. These activities are supported, respectively, by the NGO International Rescue Committee and by UNICEF.

Efforts to improve retention rates and girls' enrollment ratios have included awareness campaigns and support for school canteens, the building of latrines, the drilling of wells and the distribution of school kits in selected establishments.

The following activities have been undertaken to raise awareness and mobilize all partners:

- Training and coaching for 300 members of parents' associations (APEs) in Lobaye Prefecture.

- With funding from Italian cooperation, the international NGO COOPI has established a 1 ha manioc field, tended by the APE, to generate income to cover high-school operating costs.

- A partnership has been established with the municipal governments of Kémo and Nana Gribizi and with their legal services to deliver birth certificates at low cost to pupils.

- 100 village community representatives have been trained in environmental, development and reproductive health issues.

- Local radio broadcasts have been raising parents' awareness of the importance of schooling for all children, and particularly for girls.

\subsubsection{Health and HIV/AIDS}

Efforts to reinvigorate the health system are being pursued in the field through recruitment, ongoing training and refresher courses for health personnel, dealing with priority programs for improving service. There has also been a new round of hiring in the civil service. Other activities 
have included: (i) the supply of consumables (condoms, laboratory reagents, ARV, antibiotics, anti-malaria and anti-TB drugs) by the Global Fund; (ii) support for NGOs, associations and community organizations (OACs) in the prevention of tuberculosis; and (iii) renovation or construction and equipping of the FOSAs (health centers).

For the priority maternal-child health programs, the government decided, after a review of the program, to move to the PCIME (Integrated Care for Childhood Diseases) level, and to this end a PCIME expansion plan has been introduced for 2007-2011. The expansion unit selected is the health district. Expansion will involve all the health districts, but priority will be given to those that are operational and to those that have limited accessibility to health services and those in which the funding has been arranged. The pace of expansion will be as follows: five districts for the first year, eight districts for the second year, five districts for the third year, and three districts for the fourth year; the fifth year will be reserved for evaluating the expansion phase.

The Expanded Program on Immunization has received financing from GAVI SSV and other partners for introducing new vaccines (Hepatitis B, Haemophilus influenzae) throughout the country. During 2008 several mass campaigns were conducted against poliomyelitis in children up to five years of age, as well as a maternal-neonatal tetanus campaign among women of childbearing age. A campaign against measles, coupled with distribution of at least 800,000 insecticide-impregnated mosquito nets, was held in December.

HIV/AIDS. On the institutional level, a National Plan for Monitoring and Evaluation of the National Strategic Framework against HIV/AIDS was validated in March 2008. To facilitate the plan's implementation, a user guide has been prepared to make it operational at the prefecture level. The prefecture technical teams will have computerized support by the end of the year. Technical documentation for strengthening capacities is now being prepared, and includes a manual of procedures for coordinating the campaign at the central and prefecture levels.

During 2008 the government also gave consideration to preparing a crosscutting medium-term expenditure framework for combating HIV/AIDS.

To step up the campaign against HIV/AIDS, tuberculosis and malaria, the government has provided further support to care facilities for affected persons (orphans and other at-risk children, and widows) living in the sub-prefecture seats. Comprehensive care for widows and orphans and for persons living with HIV is now being provided in seven prefectures and in Bangui, by a community-based NGO supported by the Global Fund and WFP.

Awareness campaigns have also been targeted at specific groups: users of roads and waterways, prostitutes, men in uniform, Pygmies, Peulhs, public and private sector workers, and inhabitants of mining areas. Some health centers have been equipped with rapid testing and fungible materials to encourage voluntary screening in health and community facilities.

When it comes to caring for persons living with HIV (ARV, nutrition etc.), including the treatment of opportunistic infections, the responsible units have been decentralized. To this end, 13 new ARV units have been created. Thanks to this decentralization, 700 new PLWHs will receive $A R V$, in addition to the more than 7,800 who are already undergoing treatment. 
Box 7 : Priority actions in the social and HIV/AIDS sector

Priority actions

(i) Recruitment of 750 additional teachers for primary school.

(ii) Introduction of educational and administrative measures to achieve a repetition rate below 20 percent in primary school in areas where schools are functioning normally.

(iii) Keeping the DTC3 vaccination rate close to 80 percent.

(iv) Distribution of at least 300,000 treated mosquito nets.

(v) HIV/AIDS: improved prevention through distribution of condoms (at least 10 million units per year).
Achievements

(i) 850 qualified teachers have been recruited and deployed in the field.

(ii) The primary school curriculum (Fondamental 1) has been revised in accordance with the "skills approach" paradigm and Decree $\mathrm{N}^{\circ} 032 / \mathrm{MENAESR} / \mathrm{D} . \mathrm{CAB} / \mathrm{DGEFP}$ of May 3, 2007, regulating repetition in primary school, was put into effect during the school year 20072008.

(iii) The DTC3 vaccination rate was close to 84 percent in 2007, and was 65 percent at the end of August 2008. As of September 2008 a new vaccine (PENTAVALENT) combining DTC with other antigens was introduced, at the recommendation of the WHO.

(iv) 840,000 treated mosquito nets were distributed (a gift from UNICEF and the World Bank).

(v) About 9 million condoms were distributed by the Ministry of Public Health and Population, UNFPA and PSI.

With partner support, a number of steps have been taken to prevent and treat HIV-related opportunistic infections (OI). Some 12,000 PLWHs have been treated for OI, and Ministry offices are being supplied with Bactrim pills. To combat the sexual transmission of HIV and STI, 200 STI kits have been supplied to the CNLS and STI guidelines have been developed. To reinforce the program to prevent parent-child transmission of HIV, training for health workers was scheduled in 30 of the country's health centers during 2008. As of August 2008, training had been provided for 113 individuals (58 men and 55 women) in 12 health centers (Kokoro Boeing, Damara, Bogangolo, Boali, Bossembélé, Yaloké, Bossongo, Mongoumba, Baganda, Boganangone, Dékoa and Mala).

Finally, to prevent transmission through blood transfusions, reagents and consumables (blood bags, etc.) have been provided for transfusions at the CMTS and in six regional hospitals.

\subsubsection{Youth and sport}

The government has undertaken to upgrade sporting facilities and to endow the country with sufficient human and material resources to provide the physical and sports education needed to make the country competitive in sports. Development strategies have paid particular attention to both aspects. Given the current educational conditions in the country, informal and extracurricular education for youth are challenges that must be addressed. 
Youth policy objectives are to develop and implement: (i) a citizenship education program for young people, and (ii) a literacy program and support for social and educational facilities for young people. Three strategic areas have been defined.

Under the youth guidance program (Programme d'Encadrement des jeunes) a National Policy for the Advancement of Central African Youth has been prepared. Another aspect is to strengthen the institutional capacities of youth organizations as partners in social-educational and socioeconomic activities for young people. Two steps have been taken to renovate and build social-educational facilities: the Sibut Youth and Culture Center is being rehabilitated, and the Birao Youth and Culture Center is under construction. Three reading and cultural centers have been restored. To expand HIV/AIDS work among young people, an exhaustive inventory of youth associations, particularly those involved in combating STI and HIV/AIDS, was conducted, and 54 NGOs working in Bangui were identified. Other measures include the holding of a national AIDS forum for youth leaders, a training seminar for "educator peers" on innovative approaches to combating STI and HIV/AIDS, and support for the establishment of "Information, Education and Listening Centers for Youth" throughout the country, following the experimental model tested in the Third Arrondissement of Bangui.

In the area of sports, the emphasis has been on strengthening the capacities of physical education teachers in order to meet the enormous needs of high schools and colleges and to equip the regions with suitable sporting facilities and equipment.

A National Sports Development Policy has been prepared and is awaiting adoption. A feasibility study was performed in 2008 for rehabilitating and equipping facilities in 17 prefectures, at a rate of four facilities per year. A feasibility study was also done for the construction of facilities to train 150 youth, sports and physical education workers per year and to train trainers in these fields.

\subsubsection{Employment}

To combat poverty more effectively, the PRSP commits the government to a full-employment policy. It calls for improving the regulatory and institutional framework and adapting it to the socioeconomic context, and for promoting decent and permanent jobs. The government is aware that investment alone will not be enough to create the jobs needed, and that specific job creation policies and programs will have to be introduced.

The ACFPE training agency has submitted three projects under the PRSP: (i) an apprenticeship fund for vocational training; (ii) an employment support fund to help young people enter or reenter the labor market; and (iii) a machine shop ["maison d'outils"]. Progress to date:

- The agency used its own funds to do an inventory of all vocational training centers and NGOs working in this field throughout the country, in April 2008. Some 60 young people have received apprenticeship training with artisans and at the trades school.

- Through the employment support fund, it has established a facility whereby young people can obtain bank loans to finance income- and employment-generating activities; this project has already helped some 20 beneficiaries. 
- It financed a feasibility study for tools depots, now underway in four prefectures (Lobaye, Mambéré Kadeï, Ouaka and Ouham); a study and information mission to Dakar is planned to discover how these depots work.

- 40 labor inspectors and supervisors have been trained.

- A machine shop has been constructed.

- 120 young people have been trained in specialized workshops.

Apart from these activities, the agency has sponsored labor-intensive works in local communities of the Fourth Arrondissement of Bangui, Bossangoa, Mbaiki and (coming soon) Berbérati. These activities have provided day jobs for young people. The agency has made approaches to the JPN (National Young Pioneers program) to support training and job-finding activities.

On other fronts, an expanded technical committee is being set up to prepare the national forum that is to develop the national employment and vocational training policy, and a new labor code is under study.

\subsection{Poverty assessment indicators}

The PRSP was prepared on the basis of a 2003 poverty profile that established the benchmarks against which progress was to be measured periodically. The present annual review comes only one year after the PRSP was introduced, and there is no new poverty profile available for evaluating changes since 2003. Poverty can be assessed, nevertheless, using some indirect elements and the results of the 2006 Multiple Indicators Cluster Survey (MICS).

\subsubsection{Income indicators}

While awaiting the results from the 2008 CWIQ survey, the data from which are now being processed, there are some indicators available for deriving an indirect appreciation of people's incomes and assessing the impact of actions to date. Those indicators are:

- The characteristics of growth.

- The trend in the public service payroll.

- The trend in forestry taxes paid to the communes.

- The trend in subsistence farming and cash crop production.

Economic growth was around 2.8 percent in 2008, representing a decline from 2007 in the rate of wealth creation. An analysis of this performance allows for some assumptions about its impact on household living standards. First, although it has slowed, the economic growth rate still outstrips the demographic growth rate, which suggests that, ceteris paribus, there was no decline in per capita incomes between 2007 and 2008. Second, a sectoral breakdown of growth shows that growth was sustained in 2008, as in 2007, by the livestock and the public works and civil engineering sectors: livestock operators (farmers, merchants and other intermediaries), who account for 12 percent of GDP, can thus be credited with increasing incomes between 2007 and 2008 , as can construction and public works operators. In the latter sector, the government plans to broaden the income distribution base by pursuing labor-intensive public works. 
The public service payroll showed an upward trend between 2007 and 2008, representing higher incomes for an important segment of the population. In 2008, public servants were paid a total of US\$73.8 million (CFAF 36.9 billion) compared to US\$72.6 million (CFAF 36.3 billion), for an increase of 1.7 percent. That increase can be attributed to public service hiring, to the regular payment of salaries, and to the clearance of salary arrears. In addition, the 2008 budget retired a good portion of the domestic commercial debt. Thanks to these payments, government suppliers were able to meet their commitments and their consumption expenses. On this score, nearly US\$3.8 million (CFAF 1.9 billion) in commercial arrears were cleared for the priority sectors (education, health, rural development and social affairs) alone. This analysis confirms that consumption is still driving growth in the CAR.

The forestry tax includes stumpage fees and a reforestation charge. The proceeds go to the State, to the ministry responsible for forests, and to the communes. The communes receive 30 percent of the stumpage fee and 25 percent of the reforestation charge. These funds are paid to the communes with the primary objective of sustainable forest management. In principle, these taxes are designed to assure a decent standard of living for forest communities by encouraging them to abandon indiscriminate cutting in favor of rational exploitation and sustainable development of the forest. The forestry taxes paid to the communes between 2007 and 2008 represent significant financial resources for investing in social infrastructure such as schools, health centers, roads and markets. They should also make it possible to finance income-generating activities such as livestock raising, in place of the forest products to which local people no longer have access. Taxes paid to the communes in 2008 amounted to US\$1.7 million (CFAF 847 million) versus US\$1.9 million (CFAF 961 million) in 2007. Despite this decline, the government intends to ensure that these resources are put to good use in improving local living conditions. For that reason it has established an inter-ministerial committee that will vet the communes' proposals for using these resources before it authorizes any allocations from the funds, which will now be deposited into a holding account at the BEAC. The government also plans in the near future to make communes outside the forests eligible for revenues from the tax.

The trend in agricultural output, whether of cash crops or of staple foods, is an important indicator in assessing the dynamics of rural incomes, which are more precarious and volatile than urban incomes. Unfortunately, output both of cash crops (cotton, coffee and tobacco) and of staple foods (corn, manioc, groundnuts, millet, sorghum and potatoes) was virtually stagnant in 2008, and this has been damaging to farmers' living standards. Under these circumstances, the government is seeking to maintain producer prices for key cash crops such as coffee and cotton at a reasonable level in order to save farmers from impoverishment and to give them an incentive not to abandon these plantations for other crops.

\subsubsection{Standard-of-living indicators}

Indicators of living standards have shown some slight improvement since 2003, but they are still deemed inadequate. In the health field, infant and child mortality rates remain high. According to the 2006 MICS the infant mortality rate dropped from 130.6 to 106 per thousand between 2000 and 2006, and the child mortality rate fell from 220 to 176 per thousand between 2003 and 2006: the later figures represent an improvement from 2000 and 2003, but they are still higher than they were in 1995. The 2006 figure means that, of every 1000 live births, 176 children died before their fifth birthday, compared to 157 children in 1995, even if they would seem to be better protected. Moreover, 23.2 percent of children under 59 months were underweight in 1995, while 
the corresponding figure was 24.2 percent in 2000 and 28.2 percent in 2006 . The AIDS prevalence rate in 2006, at 6.2 percent, placed the country among the most severely affected in the region. This scourge constitutes a growing problem for development, for it is leading to a drastic loss of human capital and declining life expectancy, which was only 39 years in 2006, compared to 41 years in 2000 and 49 years in 1993.

The gross enrollment ratio in primary school (which counts all children registered at school regardless of their age) was 102 percent in 2006, reflecting late enrollment and a high repetition rate: many children enrolled in primary school are of secondary school age. The net enrollment ratio (which measures the percentage of children ages 6 to 11 enrolled in primary school) is 51.4 percent, meaning that barely one child in two of primary school age is registered at school. This ratio is 55.8 percent for boys and 46.7 percent for girls. The literacy rate for persons aged 15 to 24 years declined between 2003 and 2006, from 56.7 percent to 45.7 percent for boys and from 37 percent to 25.9 percent for girls. Educational facilities, which were already run-down, have suffered the full impact of the crisis at all education levels. Moreover, there is a glaring shortage of teachers and the erosion of funding has precluded programs to upgrade teacher qualifications. As a result, the quality of the country's education system is among the lowest in the region.

The 2006 MICS data on durable goods ownership show that households are chronically underequipped. Fewer than 50 percent of households have a radio, while only 7.8 percent have electricity service and 4.4 percent have a television set. In only 8 percent of households is there at least one person who owns a fixed or mobile telephone, a very low proportion in the ICT age.

It is expected that the various achievements during the first year of the PRSP will mean some improvement at least in those indicators that in 2006 showed a favorable trend.

\section{Constraints and outlook}

Substantial progress has been made in PRSP implementation. In particular, the implementation of sectoral committees has led to more consistent government action. A number of constraints, however, are still impeding more effective strategy implementation and may lead to disappointing results. We also note that the outlook reflects opportunities that should be used advantageously to enable the Central African Republic to succeed in the medium term in substantially improving the population's living conditions.

\subsection{Main constraints and threats}

Effective PRSP implementation requires a series of conditions-most importantly the mobilization of resources, and an effective institutional framework and domestic and international economic environment. After one year of PRSP implementation in the C.A.R., we note that the main constraints and threats that have prevailed involve (i) mobilization of resources, (ii) insufficient human resource capacities, (iii) the international financial and economic crisis; and (iv) a number of constraints specific to certain sectors, and specifically agriculture, energy, and infrastructure.

Mobilization of resources. The now recurring reason for failing to complete PRSP programs and projects is the difficulty in mobilizing external resources, or the shortage of such resources. The 
context seems to be one of shared responsibility (inefficient procedures used by the partners, insufficient control by the national party, and insufficient national capacities to absorb the resources that have been mobilized) when the Paris Declaration on the efficacy of aid is tentatively being implemented. The essential feature of official development assistance benefiting the C.A.R. is reflected with the predominance of humanitarian and recovery aid which increased from US\$10 million in 2005 to US\$70 million in 2007, and to more than US\$100 million in 2008. In addition, this aid is implemented through multilateral channels and nongovernmental organizations, thereby reducing the principle of country ownership of all program segments.

In light of this situation, the government and its partners agreed during the annual review of commitments at the Brussels Round Table held in Bangui on November 20, 2008 that the national party would make the necessary effort to control the procedures used by donors and lenders and to meet the other conditionalities for disbursement (counterpart funds, project maturity, etc.) often imposed by donors, while the donors and lenders will make every effort to streamline disbursement procedures as much as possible in light of the C.A.R.'s "fragile state" status.

Insufficient human resource capacities The situation in terms of human resource capacities in the Central African Republic is a substantial constraint against development. In 2006, 48.6 percent of school age children (6-11 years of age) were not enrolled in school; the illiteracy rate for persons 15-24 years of age was 46 percent for boys and 26 percent for girls; and the net primary school enrollment rate was 51.4 percent. Labor productivity is therefore a problem, and it is a challenge to make the C.A.R.'s population into a true engine for socioeconomic development. Although the conditions have yet to be established to make the Central African Republic into a society of knowledge in the short or medium term, the government, mindful of the threat, intends to focus on human capital formation, particularly through (i) high-quality primary education for all, throughout the country; (ii) high-quality secondary education and preparatory studies for higher education in priority technological streams to support the development of national industry; (iii) occupational training focusing on acquiring know-how with priority focus on meeting the requirements of the local populations; (iv) more professional university education; and (v) extended continuing education supported with a system designed to build on experience. These efforts will facilitate implementation of the institutional reforms now under way to modernize the administration. If nothing is done to strengthen human resource capacities, there is a risk that the poverty now existing in the C.A.R. will be handed down to future generations, as human resources are required to transform material, financial, and logistical resources in the process of development.

International financial crisis. In the short and medium terms, the international financial crisis and its economic repercussion have led to a contraction in the Central African economy in terms of GDP, which is inconsistent with the wave of recovery that began in 2006. Where foreign trade is concerned, diamond and wood exports, which accounted for 88.8 percent of 2007 export revenue, already registered a downturn in 2008 (86.2 percent), with a revenue decline of approximately 27 percent. This situation has affected budget resources, and specifically has reduced the government's investment capacity as it must cover operating expenditure that cannot be reduced. Where the balance of payments is concerned, Central African migrants in 2007 transferred just under CFAF 6 billion into the country. The wave of layoffs observed in the host countries exposes them to the same earned income losses as other workers in these countries. We can therefore expect a decline in such transfers, with repercussions on family assistance, housing 
construction, and creation of the small and medium-sized enterprises that these transfers normally support. Where donor countries are concerned, we should note that the observed economic slowdown will lead to reduced budget revenue, not including borrowing, and that diminishing resources must be used to meet numerous requests for financial support to the ailing banking sector and other areas of the economy in difficulty. This major financial support that donor countries give to their banking systems and enterprises affected by the economic recession may mean that they will contribute less to official development assistance. We can increasingly expect this crowding-out effect in the Central African Republic as it must already justify sufficient domestic capacities for effective mobilization of the aid flows now granted.

Main sectoral constraints. Agriculture, energy, and infrastructure are sectors the government relies on to boost growth with a view to raising the general standard of living and especially to reducing poverty. The dynamic PRSP scenario was quite positive in forecasting sound performance in these sectors, which unfortunately ran into substantial constraints.

As in other sectors, the sector strategy was designed to establish intra-sectoral strategies and inter-sectoral complementarities essential for sector development to be integrated harmoniously. Accordingly, project stakeholders focus more on microeconomic than macroeconomic objectives in making their decisions ${ }^{1}$. These sector stakeholders would have preferred for the liberalization to be achieved with accompanying measures related to financing, the supply of inputs, and rehabilitated rural infrastructures, which are now the two major constraints to development in this area.

In the area of energy, dependence on petroleum imports and the electricity deficit, which also registers a downward trend (-3.9 percent for water and electricity in 2008), are considered major structural constraints for the C.A.R.'s economy. The government is aware that it cannot reach its growth objectives unless it finds a sustainable solution to these problems.

Infrastructures provide the essential foundation for building economic development and competitiveness. They reduce production costs, facilitate economic activity, increase production volume, and stimulate social progress. The access rate to these infrastructures is very low, whether social (health and education infrastructures) or economic (transportation: roads, bridges, airports, ports; public utilities: energy production and distribution, water distribution systems, sewers; and telecommunications). Their functionality should also be sufficiently advanced to encourage development of a private sector worthy of the name.

\subsection{Outlook and main opportunities}

Despite the problems encountered and a number of threats impeding short-term PRSP implementation, the medium-term context for the exercise includes a number of opportunities that the government intends to exploit to reverse the current poverty trend. These activities specifically include the (i) start of major works; (ii) implementation of development poles; (iii) reduction of the debt burden in connection with the HIPC Initiative; (iv) more rigorous fiscal management; (v) gradual settling of the political climate; (vi) Gleneagles Scenario in connection with the pursuit of the Millennium Development Goals; (vii) subregional integration; (viii) consideration of the recommendations from the Inclusive Political Dialog; and

\footnotetext{
${ }^{1}$ We refer to operators who engage in arbitrage between income-generating products and food products.
} 
(ix) continuation of the consolidation processes with two important components - security sector reform and Disarmament, Demobilization, and Reintegration, specifically in the areas affected by the conflicts.

Start of major works. In the medium term, the Central African Republic has sufficient potential to succeed, particularly through investments to be mobilized in support of the infrastructure sector. Such financing that has been arranged, for which mobilization is following its normal course to benefit the infrastructure sector, includes the 10th European Development Fund in the amount of approximately US\$184 million, equivalent to CFAF 92 billion, for the period 2008-12. Disbursement of some of these resources and their economic results are expected in 2009. Similarly, in the context of the EC Regional Indicative Program, the C.A.R. will benefit from community infrastructure works estimated at several dozens of billions of CFAF in 2009 and 2010. The AfDB and World Bank are now working with the government to prepare a joint country strategy that will support works in the infrastructure, education, and health sectors beginning in 2009. The Fast Track Initiative Catalytic Fund committee agreed US\$37.78 million for the education sector for the next three years. In primary education, these resources will finance a program to build and rehabilitate schools, to train and hire contractual teachers, to buy textbooks, and to support capacity building for the Ministry of Education. Preparation by the French authorities of the debt collection program with the Central African Republic and the forthcoming resumption of cooperation with the International Fund for Agricultural Development (upon the settlement of payment arrears by the EC) are new factors that bode well for resumed cooperation and investment. Some opportunities may arise if nontraditional bilateral players become interested the potential the C.A.R. offers.

Development poles project. In connection with PRSP implementation, the government plans to implement development poles designed to be true engines for regional economic growth that meet the requirements to control and steer the national economy toward equitable, harmonious development of the country as a whole, to ultimately eliminate regional disparities. Conceptually, the development poles are designed to organize local energies to support the community development objectives, to ensure that an optimal mix of local resources and those outside the region is used to optimize its potential in the use of comparative advantages to promote territorial development, inter-regional trade, and to increase the standard of living. In fact, the consensual choice of a city as a focus for the initial development efforts can promote the multisector approach to development, participation and ownership of the people, and multiplier effects of the results and repercussions of these efforts. This development poles project, which inherently aims at more direct interventions in support of rural poverty reduction, will register far-reaching accomplishments for 2009 and 2010. Beyond the questions of revenue in monetary terms, the development poles will have the capacity to provide a package of community services (schools, health centers, housing, roads, water and sanitation, etc.) at more reasonable costs as the population is concentrated in a small geographic area. A financing arrangement was signed with the United Nations Human Settlements Programme (UN-HABITAT) to conduct monographic studies in the cities selected for the first phase of this important program. This agency conducted an exploratory mission in August 2008 and the monographic studies began during first-quarter 2009.

HIPC Initiative. The HIPC decision point in September 2007 gives the government grounds for optimism regarding the release of further budget resources for investment. The debt/export ratio, which was 541 percent in 2005, is expected to decline to approximately 66 percent in 2008 . The 
completion point scheduled for June 2009 should still be a major concern for the government and development partners, in light of the 2009 deadline and the effects of indebtedness in countries in this extreme context. This could constitute a new start and place the Central African economy in a context of solid recovery. The government intends to maintain its efforts to mobilize domestic resources to meet the conditions to use the portion of the debt subject to relief in connection with this initiative. The budget effects of the decision point are already apparent with a substantial increase in debt relief between 2007 and 2008. In fact, the 2008 data indicate US\$16.4 million (equivalent to CFAF 8.2 billion) in debt relief as against US\$3.4 billion (equivalent to CFAF 1.7 billion) for all of 2007. This in fact involves supplementary resources the government received to address problems related to investment or direct poverty reduction.

2009 budget. In the framework of this budget, established with assumptions that did not include any external shocks, the government intends to strengthen budget management by mobilizing additional domestic resources and through more effective resource allocation. The 2009 budget law is the foundation for the PRSP, reflecting the budgeting of the key actions adopted, specifically in priority sectors for the strategy, as well as dissemination of the government contracting code with a view to the preparation of a manual of procedures for contracting. To that end, the law provides for substantial budget increases in the relevant areas: education (10.12 percent) health ( 0.11 percent), rural development (53.2 percent), justice (12.6 percent), and defense (20.2 percent). In a fairly morose economic environment, the Government intends to redirect resource allocations to reflect the complementarity between domestic and external resources.

The much-awaited Inclusive Political Dialog (IPD) effectively took place in Bangui during December 8-20, 2008. The Dialog developed the following consensual, strong, and operational recommendations consistent with the PRSP strategic focuses. Implementation of some of these recommendations has begun with the government's establishment of a national union. The former committee responsible for monitoring national dialog recommendations was dissolved and replaced with a new committee deriving from the IPD recommendations. This effort, which was undertaken with a peaceful approach, is a source of hope for the Central African people of regaining unity and catalyzing new development dynamics. The international community will draw lessons from the IPD to provide further support for the local development efforts, particularly against the backdrop of a more favorable business climate.

The application of these recommendations in accordance with Priority Action Program in PRSP implementation undertaken for the period 2009-2010 should establish linkages between the important Disarmament, Demobilization, and Reintegration Program focusing on former rebels and national and community disarmament.

Gleneagles Scenario. During the G-8 summit held in Gleneagles in 2005, developed countries undertook to double official development assistance in support of Sub-Saharan African countries to accelerate implementation of the Millennium Development Goals. If maintained, this commitment would mean an increase in official development assistance from US\$25 billion in 2004 to US\$50 billion in 2010, equivalent to US\$85 dollars per person in 2010. To make this commitment operational, the Secretary-General of the United Nations has implemented a committee of 20 donors and lenders who have selected approximately 20 countries, including the Central African Republic, to test the scenario. With UNDP support, the C.A.R. evaluated the cost of achieving the Millennium Development Goals in the key sectors (education, health, rural 
development, infrastructures, gender issues, and peace consolidation and conflict prevention). This assessment showed that the Central African Republic's additional requirements to achieve the Millennium Development Goals, taking into account the requirements for PRSP implementation, amount to US\$220 million per annum for the period 2008-2015. The report on this Scenario was validated at the national level and presented to the Annual General Assembly of the United Nations in September 2008. The examination of the C.A.R.'s case simultaneously with the other countries involved led to an initial endowment of US\$10 billion in an initial financing stage for 10 countries. The Central African Republic is preparing to use the finalization of this Gleneagles commitment to accelerate the process of achieving the Millennium Development Goals and thus further reduce poverty.

Subregional integration. Inaccessibility is one of the constraints to development in the C.A.R.. Sub-regional integration is an important scenario in reducing these constraints. In this connection, the Regional Indicative Program supported by the European Community in connection with the Economic and Monetary Community of Central Africa (CEMAC) provides an opportunity to benefit from the Community's infrastructures to reduce transaction costs for the C.A.R.'s economy. The Regional Economic Program (REP) is being implemented in the dynamics of intra-community solidarity. The integrating approach, contribution to job creation and to subregional trade, and public/private partnership potential are priority factors in selecting projects to be adopted in connection with the REP. This context applies to the Central African Republic, from which it stands to benefit.

Cotton and the integrated framework. Where cotton is concerned, US\$ 1.13 million, equivalent to CFAF 566,100,000, is provided under the Japanese grant to support the 2009/2010 growing season for hippomobile planting and the purchase of inputs. In connection with the integrated framework, the outlook entails use of the remaining US\$370,000 (out of the US\$1 million initially mobilized by the World Trade Organization), to be devoted to: (i) continuation of project s launched in 2008; (ii) two studies on the establishment of a trade and credit promotion center; (iii) training of economic players and sectoral committees members; and (iv) project completion audit management. Similarly, there are plans to migrate to a reinforced integrated framework.

\section{Conclusion}

The first year of PRSP implementation is characterized by an unfavorable international economic environment, with its repercussions on the national economy. The various external shocks, particularly those related to fluctuations in the price per barrel of oil, instability in key export prices, the world food crisis, and the international financial crisis have led to instability in budget resources, a surge in inflation, an aggravated foreign trade deficit, and slowed growth.

Despite this unfavorable economic cycle, with the help of its development partners, the government has established an institutional framework for PRSP implementation, monitoring, and assessment. The balance of accomplishments provided in item 5 of this report indicates that substantial actions, essential to prevent further deterioration in the country's economic situation by end-2008, were effectively taken. This approach has permitted a recovery in various sectors, to optimize their preparation as players in the national economy. The government simultaneously pursued implementation of the Poverty Reduction and Growth Facility program supported by the Bretton Woods Institutions. 
The main difficulties encountered in PRSP implementation relate to the mobilization of resources, making the institutional framework for strategy monitoring and assessment operational, and insufficient human resource capacities. Other problems are more peculiar to certain sectors, specifically agriculture, energy, and infrastructures, which are essential factors in the rehabilitation of the C.A.R.'s economy, which has been shaken by the many conflicts during the period 1996-2003. The government's commitment to make every effort to control the procedures for disbursement of funds, and to comply with other conditionalities for the release of external resources, and the fact that the development partners are considering streamlining these procedures to reflect the Central African Republic's status as a "fragile state" bode well for an easing of such difficulties in the short term.

The pursuit of PRSP implementation exercise fits in this context, characterized by many opportunities to be taken by the government to reverse the poverty trend. In particular, this effort involves (i) the start of major works that will have effectively taken place in 2009; (ii) implementation of development poles to federate the participatory approach, upgrading of local resources and multisector approaches to boost regional development; (iii) repercussions of the HIPC Initiative (attainment of the completion point) that will increase public investment capacities; (iv) continued mobilization of resources; (v) capacity building for the implementing agencies to enhance the absorption and effective use of the mobilized resources; (v) more rigorous fiscal management; (vi) gradual easing of the political and security climate, which will have repercussions on the business environment; and (vii) subregional integration, through the Regional Indicative Program of the European Commission and the CEMAC Regional Economic Program, from which the C.A.R. can benefit to eliminate its isolation. 
Annexes 
Annex 1. PRSP Implementation Monitoring Matrix

\begin{tabular}{|c|c|c|c|}
\hline PERFORMANCE INDICATORS & $\begin{array}{c}2008 \\
\text { benchmark }\end{array}$ & $\begin{array}{c}\text { Level } \\
\text { achieved in } \\
2007\end{array}$ & Comments \\
\hline \multicolumn{4}{|l|}{ Security } \\
\hline Number of military personnel receiving civic and moral training & 960 & 960 & \\
\hline Number of press outlets in connection with confidence building efforts & 4 & 0 & - \\
\hline $\begin{array}{l}\text { Number of awareness campaigns targeting the local populations in garrison } \\
\text { rehabilitation areas }\end{array}$ & 12 & 12 & \\
\hline Number of barracks built & 4 & 0 & $\begin{array}{l}\text { Financing sought for } \\
\text { barracks construction }\end{array}$ \\
\hline $\begin{array}{l}\text { Number of judiciary police officers who have received a minimum of } 9 \text { months } \\
\text { training }\end{array}$ & 40 & - & $\begin{array}{l}\text { Financing sought for } \\
\text { training }\end{array}$ \\
\hline $\begin{array}{l}\text { Number of uniforms provided for members of the Defense and Security Forces } \\
\text { (FDS) }\end{array}$ & 300 & 300 & $\begin{array}{l}\text { This achievement } \\
\text { applies only to the } \\
\text { police. }\end{array}$ \\
\hline Number of persons demobilized and reintegrated & 7,000 & 4590 & $\begin{array}{l}\text { Source: Project for } \\
\text { reintegration of } \\
\text { veterans and } \\
\text { community support } \\
\text { (PRAC) }\end{array}$ \\
\hline Number of police officers recruited and trained & 400 & 0 & $\begin{array}{l}\text { Financing sought for } \\
\text { training }\end{array}$ \\
\hline
\end{tabular}

Justice

\begin{tabular}{|c|c|c|c|}
\hline Number of legal texts revised & 8 & 0 & In progress \\
\hline Number of codes disseminated & 1 & 1 & \\
\hline Number of codes translated into Sango & 0 & 0 & \\
\hline Adoption of a legal career framework for magistrates & 3 & 3 & \\
\hline Number of magistrates recruited and trained & 42 & 42 & \\
\hline Number of bailiffs trained & 5 & 5 & \\
\hline Number of prison managers and female wardens trained & 16 & 16 & \\
\hline Number of courthouses built & 2 & 2 & \\
\hline Number of remand centers built or rehabilitated & 4 & 4 & $\begin{array}{l}\text { Two built and two } \\
\text { rehabilitated }\end{array}$ \\
\hline
\end{tabular}

\section{Governance and human rights}

Number of professional and technical staff who have participated in human rights training

10

10

Number of awareness and education campaigns for the public, local administrative authorities, and defense and security forces

Number of legal texts revised and adapted to international standards submitted to the National Assembly

Establishment of a structure to fight corruption, misappropriation, and other similar violations

Number of buildings built to accommodate decentralized services

Number of buildings rehabilitated to accommodate decentralized services

Establishment of a legal monitoring and assistance service for victims of human rights violations and corruption within the High Commission for Human Rights and Governance
This indicator will not be measured until 2009

This indicator will not be measured until 2009

This indicator will not be measured until 2009

This indicator will not be measured until 2009

This indicator will not be measured until 2009

This indicator will not be measured until 2009 


\begin{tabular}{cccc}
\hline PERFORMANCE INDICATORS & $\begin{array}{c}2008 \\
\text { benchmark }\end{array}$ & $\begin{array}{c}\text { Level } \\
\text { achieved in } \\
2007\end{array}$ & Comments \\
\hline & Business climate (trade) \\
\hline
\end{tabular}

Number of documents on industrial and commercial policy and development strategy for the private sector prepared by the ministry

Number of texts prepared, revised, and harmonized by the ministry

Establishment of a legal framework for state-private sector consultation

Number of training seminars organized by the Ministry of Trade, Industry, and Small and Medium-Sized Enterprises (MCIPME) targeting the private sector

\section{2}

2

7

\section{Promotion of gender equality and equity}

Existence of a national legal instrument promoting equal opportunities for both

genders

\begin{abstract}
Existence of the initial report and periodic reports of the Convention to eliminate all forms of violence against women (CEDEF)
\end{abstract}

C.A.R. commercial policy document Commercial Code Commercial code harmonized with regional and international texts Revised investment charter

This indicator will not be measured until 2009

Financing problems 


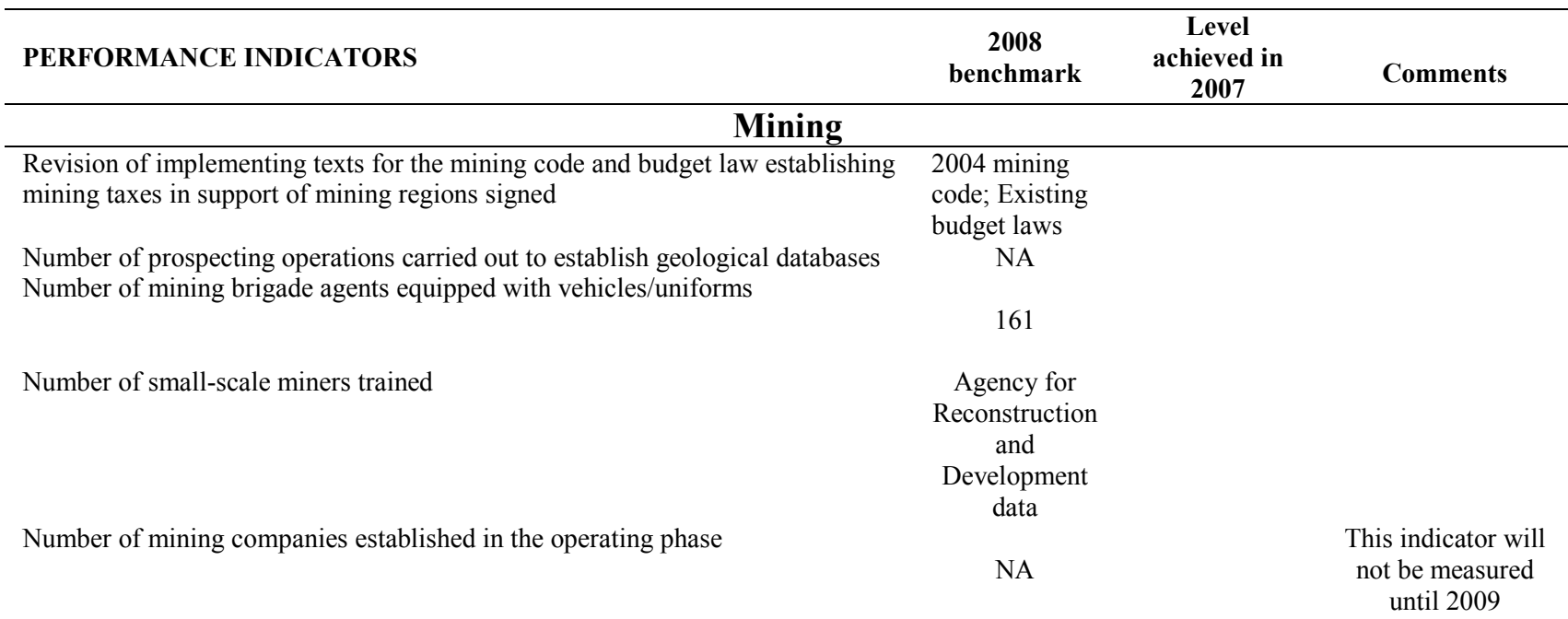

\section{Infrastructure and transportation}

Linear kilometers, roads rehabilitated or resurfaced Linear kilometers, unpaved roads rehabilitated

Linear kilometers, rural roads rehabilitated

Number of engineering works rehabilitated or built

$\begin{array}{ccc}585 & 0 & \begin{array}{c}\text { No feasibility study } \\ \text { and financing } \\ \text { problems }\end{array} \\ 2546 & 733 & \begin{array}{c}\text { Insufficient loan } \\ 2 \text { works built } \\ 1524\end{array} \\ & 206 & \begin{array}{c}50 \text { works } \\ \text { rehabilitated }\end{array}\end{array}$

\section{Waterways and forestry}

Number of structures and associations supported and trained in connection with forest resource co-management

Number of leaders trained

Number of awareness sessions and meetings organized

Development policy operations

Tracking capability Container

Number of professionals trained by the Ministry exports

Number of professionals from the regional departments trained

8

175

One ( Forestry code) and

Number of texts, codes revised, adopted, and applied implementing texts

One Forestry code adopted and promulgated

Number of operating permits granted to forestry enterprises by the ministry Number of local management committees trained in resource management Regulations prepared, adopted, and applied

Number of forestry enterprises having forestry development plans

Number of cynegetic village areas established

Energy

Number of implementing texts for the electricity code Production level provided by the capacities of Boali 1 and 2 Number of professionals who have attended GIS training Available power (MW) Number of transport lines rehabilitated, medium tension $(\mathrm{Km})$ until 2009 


\begin{tabular}{|c|c|c|c|}
\hline PERFORMANCE INDICATORS & $\begin{array}{c}2008 \\
\text { benchmark }\end{array}$ & $\begin{array}{c}\text { Level } \\
\text { achieved in } \\
2007\end{array}$ & Comments \\
\hline Number of lines rehabilitated, low tension $(\mathrm{Km})$ & 500 & & \\
\hline Number of transportation lines rehabilitated (transport lines) $(\mathrm{Km})$ & 130 & & \\
\hline \multicolumn{4}{|l|}{ Number of price structure audits for petroleum products carried out } \\
\hline \multicolumn{4}{|c|}{ Water and sanitation } \\
\hline Number of boreholes built in rural areas & 80 & 144 & \\
\hline Number of boreholes rehabilitated in rural areas & 200 & 280 & \\
\hline Number of standpipe enclosures built in urban areas & 40 & & \\
\hline Number of new individual hookups in urban areas & 300 & & \\
\hline Number of VIP latrines built & 50 & 66 & \\
\hline Number of traditional latrines built or developed & 1,800 & 1,630 & \\
\hline
\end{tabular}

\section{Arts and culture}

Number of cultural exchanges established

Number of districts and localities in the provinces serviced by the neighborhood
culture project

Number of districts and localities in the provinces serviced by the neighborhood
culture project

\section{Arts and culture}
Construction of a cultural center
Number of sites rehabilitated

NA
Project
implementa-
tion in two
districts of
Bangui and
Bimbo
Feasibility study

5
This indicator will not be measured until 2009

Neighborhood culture projection two districts of Bangui

(Kpètènè 1 and

2 in the 6 th district,

Galabadja in the eighth', and Bimbo

(Gbalikola 2)

Feasibility study available with support from UNESCO 3

Financing sought to build a cultural center

Financing sought

\section{Tourism}

\begin{tabular}{|c|c|c|c|}
\hline Number of economic players subject to capacity building in the tourism area & 1,600 & 70 & $\begin{array}{l}\text { - The } 70 \text { persons } \\
\text { trained are from } \\
\text { the following } \\
\text { structures: } \\
\text { BAMELEC; } \\
\text { AZIMUT, and } \\
\text { Le Méridien } \\
\text { Restaurant }\end{array}$ \\
\hline $\begin{array}{l}\text { Number of personnel from the National Tourism Association subject to capacity } \\
\text { building in the area of hospitality } \\
\text { Number of inns }(1,500-2,000 \text { rooms) built for tourism or rehabilitated near } \\
\text { the stations }\end{array}$ & Not known & 20 & \\
\hline Number of tourism hotels built in the provinces having a capacity of 15 rooms & NA & 0 & $\begin{array}{c}\text { Financing } \\
\text { problems } \\
\text { This indicator will } \\
\text { not be measured } \\
\text { until } 2009\end{array}$ \\
\hline Number of ecotourism sites developed & 1 & 0 & $\begin{array}{l}\text { Financing } \\
\text { problems }\end{array}$ \\
\hline Number of artisanal sites built & 4 & 0 & $\begin{array}{l}\text { Financing } \\
\text { problems }\end{array}$ \\
\hline
\end{tabular}

\section{Education}

\begin{tabular}{llll}
\hline Number of F-1 classrooms rooms rehabilitated & 200 & & \\
Number of F-1 classrooms rooms built & 500 & 6 & Financing problems \\
\hline
\end{tabular}




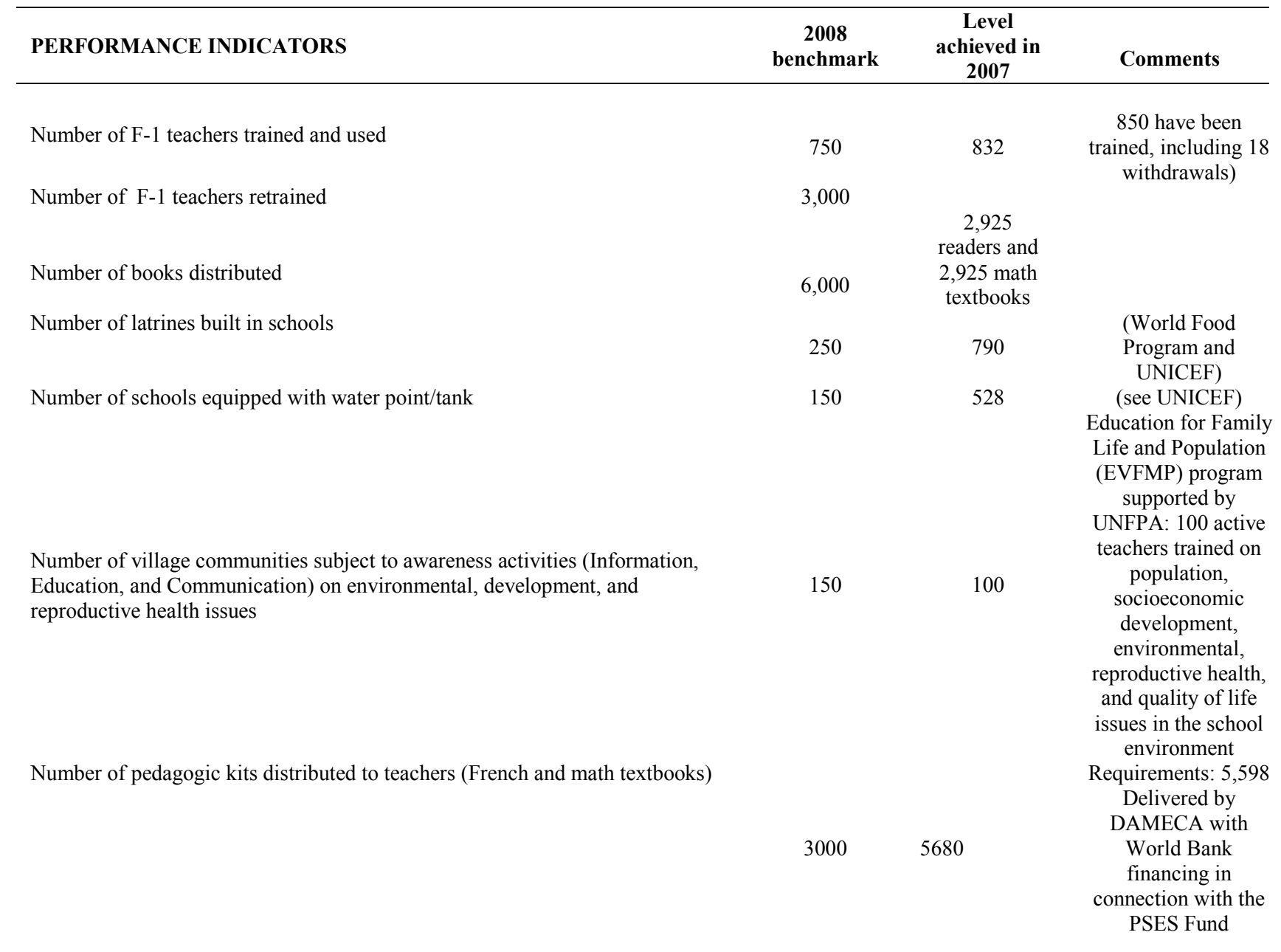

\section{Health}

Number of health education centers (FOSAs) rehabilitated by type

Health unit

Health center $(\mathrm{C})$

Health center (B)

Health center (A)

Prefect hospital

Regional hospital

Central hospital

Number of FOSAs built (by type)

Number of health personnel by category

Number of general physicians trained

Number of specialized physicians trained

Number of technicians trained

Number of midwives/maternity nurses trained

Number of state diploma nurses trained

Number of maternity assistants trained

Number of staff trained to treat malaria
This indicator will not be measured until 2009
This indicator will not be measured until 2009

$\begin{array}{rc}\text { Health unit } & 453 \\ \text { Health center (C) } & 124 \\ \text { Health center(B) } & 52 \\ \text { Health center (A) } & 39 \\ \text { Prefect hospital } & 20 \\ \text { Regional hospital } & 6 \\ \text { Central hospital } & 1 \\ & 113 \\ & 10 \\ & 94 \\ & 221 \\ & 298 \\ & 253\end{array}$




\begin{tabular}{|c|c|c|c|}
\hline PERFORMANCE INDICATORS & $\begin{array}{c}2008 \\
\text { benchmark }\end{array}$ & $\begin{array}{c}\text { Level } \\
\text { achieved in } \\
\mathbf{2 0 0 7} \\
\end{array}$ & Comments \\
\hline \multicolumn{4}{|l|}{ HIV/AIDS } \\
\hline Number of persons receiving HIV counseling and screening & 75.000 & 32010 & \\
\hline $\begin{array}{l}\text { Number of persons receiving HIV counseling and screening who know their } \\
\text { serological results }\end{array}$ & 67,500 & 29,100 & \\
\hline Number of condoms distributed & $10,000,000$ & $8,926,198$ & $\begin{array}{c}\text { National Committee } \\
\text { to fight AIDS } \\
\text { (CNLS)+Central } \\
\text { African Association } \\
\text { for Social Marketing } \\
\text { (ACAMS)+UNFPA } \\
\text { in addition to } \\
8,804,880 \text { sold by } \\
\text { PSI }\end{array}$ \\
\hline $\begin{array}{l}\text { Number of operational sites for prevention of parent/child transmission of } \\
\text { HIV/AIDS (PTPE) }\end{array}$ & 60 & 65 & \\
\hline Number of persons trained in anti-retroviral treatment and CTM prophylaxis & 250 & 75 & PSES project \\
\hline $\begin{array}{l}\text { Number of FOSAs having anti-retroviral treatments, prescribe them, and/or } \\
\text { provide clinical follow-ups }\end{array}$ & 50 & 62 & \\
\hline
\end{tabular}

\begin{tabular}{|c|c|c|c|}
\hline PERFORMANCE INDICATORS & $\begin{array}{c}2008 \\
\text { Benchmark }\end{array}$ & $\begin{array}{l}\text { Level achieved } \\
\text { in } 2008\end{array}$ & Comments \\
\hline
\end{tabular}

\section{Employment}

Promulgation of the National Employment and Occupational Training Policy Paper

Number of texts, codes revised, adopted, and applied

Establishment of the Permanent National Labor Council

Number of labor inspectors or auditors trained or retrained within the ministry and operational

Existence of a legal framework and partnerships between the training organizations and enterprises
Implementation of the preparatory committee for the national forum on employment and occupational training

NA

Implementing decree for the ordinance establishing the National Permanent Labor Council

40
The bureau of the preparatory committee has been established

Labor code revised, adopted, and disseminated in all labor inspectorates

No

40
The process for preparing the forum is under way.

This indicator will not be measured until 2009
Yet to be implemented
Labor Department (DGT) + Central African Agency for Vocational Training and Employment

(ACFPE)

One directory One study available
The prefectures of Vakaga, Bamingui

Bangoran, and

Haut-Mbomou

have not been covered owing to their inaccessibility Lack of financing 


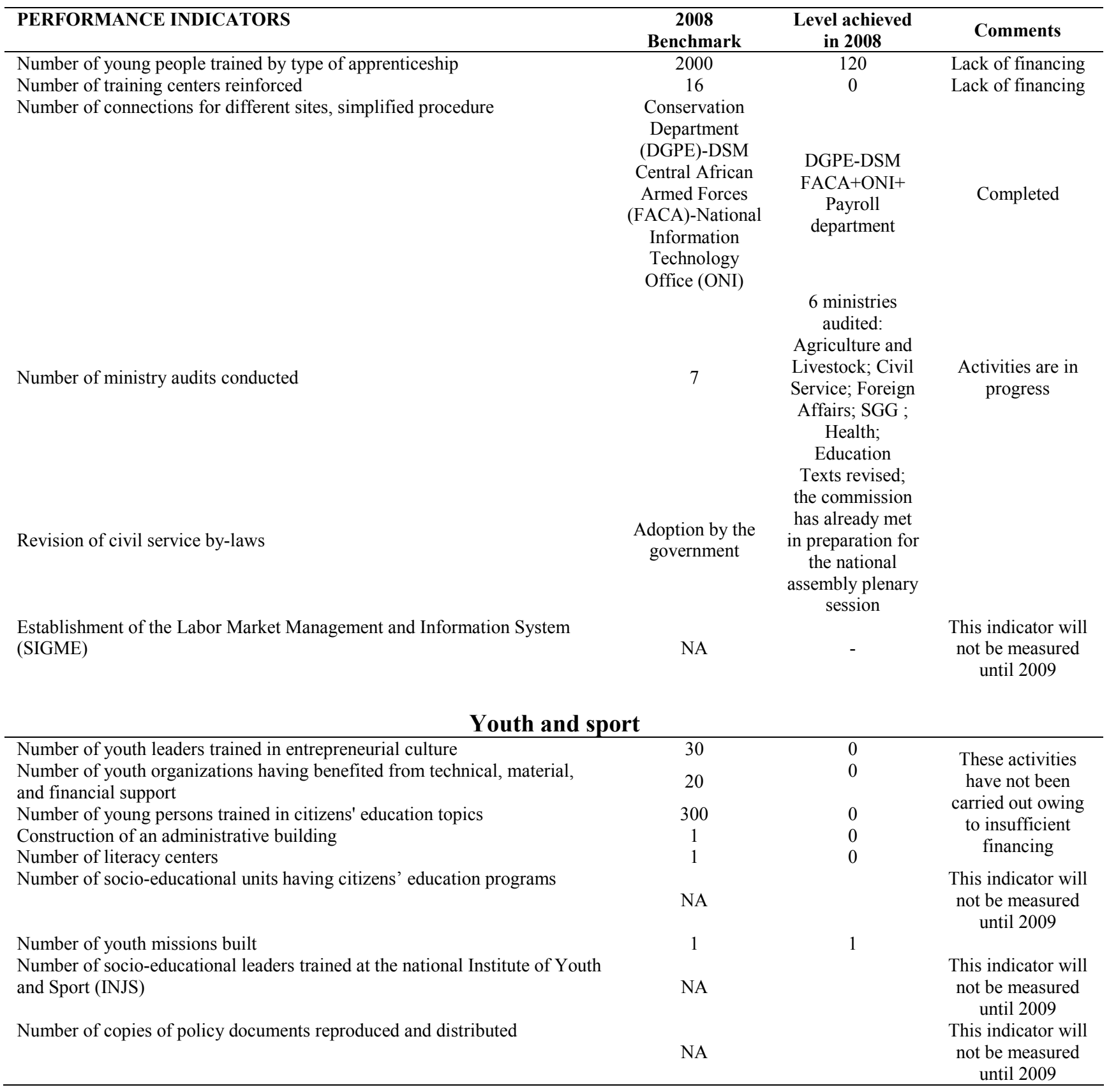


Annex 2. PRSP performance monitoring matrix

\begin{tabular}{|c|c|c|c|c|}
\hline PERFORMANCE INDICATORS & $\begin{array}{c}\text { Benchmark } \\
\text { (2006 or 2007) }\end{array}$ & $\begin{array}{c}2008 \\
\text { Benchmark }\end{array}$ & $\begin{array}{c}\text { Level } \\
\text { achieved in } \\
2008\end{array}$ & Comments \\
\hline
\end{tabular}

\section{Security}

\begin{tabular}{|c|c|c|c|}
\hline $\begin{array}{l}\text { Percentage of prefectures or regions having } \\
\text { operational barracks }\end{array}$ & 18 percent & 18 percent & \\
\hline $\begin{array}{l}\text { Number of communities affected by Civic } \\
\text { Military Cooperation activities }\end{array}$ & 0 & 2 & \\
\hline Population/police officer ratio & $\begin{array}{l}2,945 \text { per police } \\
\text { officer }\end{array}$ & $\begin{array}{c}3,004 \text { per } \\
\text { police officer }\end{array}$ & $\begin{array}{c}3,004 \text { per } \\
\text { police officer }\end{array}$ \\
\hline Population per gendarme & $\begin{array}{l}2,811 \text { per } \\
\text { gendarme }\end{array}$ & $\begin{array}{l}2,868 \text { per } \\
\text { gendarme }\end{array}$ & $\begin{array}{l}2,536 \text { per } \\
\text { gendarme }\end{array}$ \\
\hline
\end{tabular}

Justice

\begin{tabular}{|c|c|c|c|c|}
\hline $\begin{array}{l}\text { Average duration to process flagrante } \\
\text { delicto cases in all three courts }\end{array}$ & $8-15$ days & $8-15$ days & $15-30$ days & Insufficient number of judges \\
\hline Average duration of trials & 8 days & 8 days & 30 days & Insufficient number of judges \\
\hline Percentage of criminal trials delayed & 0 percent & 60 percent & Not known & Data not processed \\
\hline $\begin{array}{l}\text { Number of cases of misappropriation of } \\
\text { public assets taken to court }\end{array}$ & 12 & 40 & 50 & Insufficient number of judges \\
\hline $\begin{array}{l}\text { Average preventive incarceration period for } \\
\text { flagrante delicto cases }\end{array}$ & 15 days & 15 days & 30 days & Insufficient number of judges \\
\hline Population/magistrate ratio & $\begin{array}{l}42,166 / \\
\text { magistrate }\end{array}$ & $\begin{array}{l}28,682 / \\
\text { magistrate }\end{array}$ & $\begin{array}{l}22,406 / \\
\text { magistrate }\end{array}$ & +42 magistrates \\
\hline Population/court & 140,555 & $143,412 /$ courts & $195,562 /$ court & $\begin{array}{l}\text { The government must make } \\
\text { substantial efforts }\end{array}$ \\
\hline Number of operational courts in each region & 4 & 4 & $\begin{array}{l}\text { Region } 1=4 \\
\text { Region } 2=4 \\
\text { Region } 3=4 \\
\text { Region } 4=3 \\
\text { Region 5=3 } \\
\text { Region 6=4 }\end{array}$ & $\begin{array}{l}22 \text { courts distributed in the six } \\
\text { regions }\end{array}$ \\
\hline $\begin{array}{l}\text { Number of attorneys registered with the bar } \\
\text { association }\end{array}$ & 98 & 98 & 108 & $\begin{array}{l}10 \text { new attorneys are registered } \\
\text { with the office }\end{array}$ \\
\hline
\end{tabular}

Governance and human rights

Number of referrals and judgments issued
for human rights violations
Number of referrals and judgments issued
for corruption, misappropriation, and other
similar violations
Number of judgments in the area of human
rights, corruption, misappropriation, and
other similar violations submitted to the
High Commission for Human Rights and
Governance

Not known NA

Not known NA
This indicator will not be
measured until 2009
This indicator will not be

This indicator will not be
measured until 2009

This indicator will not be measured until 2009

\section{Business climate (trade)}

$\begin{array}{lccc}\text { Number of cases processed by the one-stop } & \text { Not known } & 600 & 500 \\ \text { window } & 356 & 400 & 500 \\ \begin{array}{l}\text { Number of enterprises established } \\ \begin{array}{l}\text { Period of time required to establish an } \\ \text { enterprise }\end{array}\end{array} & 1 \text { month } & 3 \text { weeks } & 7-15 \text { days }\end{array}$

\section{Promotion of gender equality and equity}

Number of women deputies
Number of women in government
Number of women in senior management
(Managing Directors, Town councilors,
Ministerial cabinet members, etc.)

$\begin{array}{ccc}10 & 10 & 9 \\ 4 & 5 & 4 \\ 40 & 50 & 42\end{array}$




\begin{tabular}{|c|c|c|c|c|}
\hline PERFORMANCE INDICATORS & $\begin{array}{l}\text { Benchmark } \\
\text { (2006 or 2007) }\end{array}$ & $\begin{array}{c}2008 \\
\text { Benchmark }\end{array}$ & $\begin{array}{c}\text { Level } \\
\text { achieved in } \\
2008 \\
\end{array}$ & Comments \\
\hline \multicolumn{5}{|c|}{ Rural development } \\
\hline $\begin{array}{l}\text { Rate of operational agricultural producers' } \\
\text { organizations }\end{array}$ & 8 & 10 & & \\
\hline $\begin{array}{l}\text { Overall rate of increase (in percent) in key } \\
\text { food output }\end{array}$ & 4 & 5 & 2.6 & \\
\hline Number of hippomobile teams used/year & Not known & 2,000 & & \\
\hline Cash crop production (in tons) & Not known & & & \\
\hline - Cotton & 2,800 & 4,000 & 3,636 & \\
\hline - Coffee & 1,600 & 2000 & 1,816 & \\
\hline \multicolumn{5}{|l|}{ Annual herd growth rate } \\
\hline - Cattle & 2.2 & 2.8 & & \\
\hline - Sheep & 5.2 & 5.5 & & \\
\hline - Goats & 5.7 & 6.1 & & \\
\hline - Pigs & 4.3 & 4.8 & & \\
\hline - Poultry & 4.2 & 4.7 & & \\
\hline $\begin{array}{l}\text { Annual rate of increase in truck farming } \\
\text { output }\end{array}$ & 4 & 5.3 & & \\
\hline \multicolumn{5}{|c|}{ Mining } \\
\hline $\begin{array}{l}\text { Geological database available } \\
\text { Share of mining revenue in total revenue }\end{array}$ & $\begin{array}{l}\text { Not known } \\
3 \text { percent }\end{array}$ & $\begin{array}{c}\text { NA } \\
-\end{array}$ & 3.02 percent & $\begin{array}{l}\text { This indicator will be measured } \\
\text { beginning in } 2009 .\end{array}$ \\
\hline \multicolumn{5}{|c|}{ Transportation and infrastructure } \\
\hline Paved road density & 0.17 & 0.24 & 0 & Financing problems \\
\hline Non-rehabilitated national road density & 0.42 & 0.45 & 00.17 & Financing problems \\
\hline Regional road density & 0.24 & 0.30 & 0.05 & Financing problems \\
\hline Rural road density & 0.05 & 0.06 & 0.012 & Financing problems \\
\hline PERFORMANCE INDICATORS & $\begin{array}{l}\text { Benchmark } \\
\text { (2006 or 2007) }\end{array}$ & $\begin{array}{c}2008 \\
\text { Benchmark }\end{array}$ & $\begin{array}{c}\text { Level } \\
\text { achieved in } \\
2008 \\
\end{array}$ & Comments \\
\hline \multicolumn{5}{|c|}{ Waterways and forestry } \\
\hline $\begin{array}{l}\text { Forest revenue from taxes in the state } \\
\text { budget }\end{array}$ & $6,500,000,000$ & $7,500,000,000$ & & \\
\hline $\begin{array}{l}\text { Rate of compliance with specifications by } \\
\text { forestry companies } \\
\text { Development in the log processing rate } \\
\text { Processing loss rate }\end{array}$ & $\begin{array}{l}45 \text { percent } \\
15 \text { percent } \\
60 \text { percent }\end{array}$ & $\begin{array}{l}56.5 \text { percent } \\
33.5 \text { percent } \\
43.5 \text { percent }\end{array}$ & & \\
\hline Development in protected areas & 11 percent & 14 percent & & \\
\hline $\begin{array}{l}\text { Number of village cynegetic areas } \\
\text { established }\end{array}$ & 8 & 7 & & \\
\hline $\begin{array}{l}\text { Number of small-scale enterprises and } \\
\text { industries established }\end{array}$ & $\begin{array}{l}10 \text { existing } \\
\text { SME/SMIs }\end{array}$ & 11 & & \\
\hline Number of studies ordered & Not known & 8 & & \\
\hline
\end{tabular}




\begin{tabular}{|c|c|c|c|c|}
\hline PERFORMANCE INDICATORS & $\begin{array}{c}\text { Benchmark } \\
\text { (2006 or 2007) }\end{array}$ & $\begin{array}{c}2008 \\
\text { Benchmark }\end{array}$ & $\begin{array}{c}\text { Level } \\
\text { achieved in } \\
2008\end{array}$ & Comments \\
\hline \multicolumn{5}{|c|}{ Energy } \\
\hline
\end{tabular}

Number of cuts (load reductions)

Average load reduction period

Developments in revenue from energy

produced

\section{Water and electricity}

$\begin{array}{lcc}\text { Drinking water coverage rate, rural areas } & 31 \text { percent } & 33 \text { percent } \\ \text { Drinking water coverage rate, urban areas } & 30 \text { percent } & 32 \text { percent } \\ \begin{array}{l}\text { Population access rate to an adequate } \\ \text { sanitary system }\end{array} & 52.5 \text { percent } & 55.0 \text { percent }\end{array}$

Arts and culture

\begin{tabular}{lcccc}
\hline $\begin{array}{l}\text { Rate of increase in commercial cultural } \\
\text { activities around the marketplaces }\end{array}$ & 0 & 15 percent & 0 percent & $\begin{array}{c}\text { Not completed } \\
\text { Number of temporary jobs created }\end{array}$ \\
$\begin{array}{l}\text { Number of permanent jobs created through } \\
\text { the development of heritage sites }\end{array}$ & 20 & 10 & 0 percent & Lack of financing (state budget) \\
$\begin{array}{l}\text { Number of management plans for cultural } \\
\text { and commercial development of sites on the } \\
\text { available indicative list }\end{array}$ & 0 & 20 & 0 percent & Lack of financing \\
& 0 percent & No financing (UNESCO) \\
$\begin{array}{l}\text { Number of reading and activity centers } \\
\text { (CLAR) built or rehabilitated }\end{array}$ & 0 & 3 & $\begin{array}{c}\text { International Organization of the } \\
\text { Francophonie (OIF) Financing } \\
\text { available; }\end{array}$ \\
& & 11 & $\begin{array}{c}\text { UNICEF support for the } \\
\text { construction of a building; State } \\
\text { budget and negotiation with } \\
\text { UNDP }\end{array}$
\end{tabular}

Tourism

\begin{tabular}{lccc}
\hline $\begin{array}{l}\text { Number of tourists visiting tourist sites } \\
\text { (Bayanga) }\end{array}$ & 586 & 849 & Token entry \\
$\begin{array}{l}\text { Number of tourists arriving to attend } \\
\text { meetings }\end{array}$ & 3,746 & 7,052 & Token entry \\
\end{tabular}

\begin{tabular}{lcc}
\hline Student/classroom ratio & $92 / 1$ & $88 / 1$ \\
Student/seat ratio & $3 / 1$ & $3 / 1$ \\
Students/trained teachers ratio & $98 / 1$ & $98 / 1$ \\
$\begin{array}{l}\text { Students/book ratio } \\
\text { Percentage of schools having sanitary }\end{array}$ & $6 / 1$ & $5.5 / 1$ \\
facilities & Not known & 15 percent \\
$\begin{array}{l}\text { Percentage of communities subject to } \\
\text { awareness activities }\end{array}$ & Not known & 21 percent \\
$\begin{array}{l}\text { Percent of teachers having kits } \\
\text { Student/classroom (F-2) ratio }\end{array}$ & Not known & 50 percent \\
Completion rate & 32 percent & $100 / 1$ \\
& & 38 percent \\
& & \\
\hline $\begin{array}{l}\text { Health service access rates in rural areas } \\
\text { Rate of births attended by trained health }\end{array}$ & 62.5 percent & 65 percent \\
personnel & 53.40 percent & 58.9 \\
$\begin{array}{l}\text { Contraceptive coverage rate } \\
\text { DTC 3 immunization coverage }\end{array}$ & 19 percent & 22.7 \\
Vitamin A supplementation rate (children & 84 percent & 80 percent \\
aged 6-59 months) & 60.2 percent & 66.8 percent \\
$\begin{array}{l}\text { Number of districts applying the integrated } \\
\text { care for childhood diseases program }\end{array}$ & & \\
(PCIME) & 11 & 8 \\
\hline
\end{tabular}




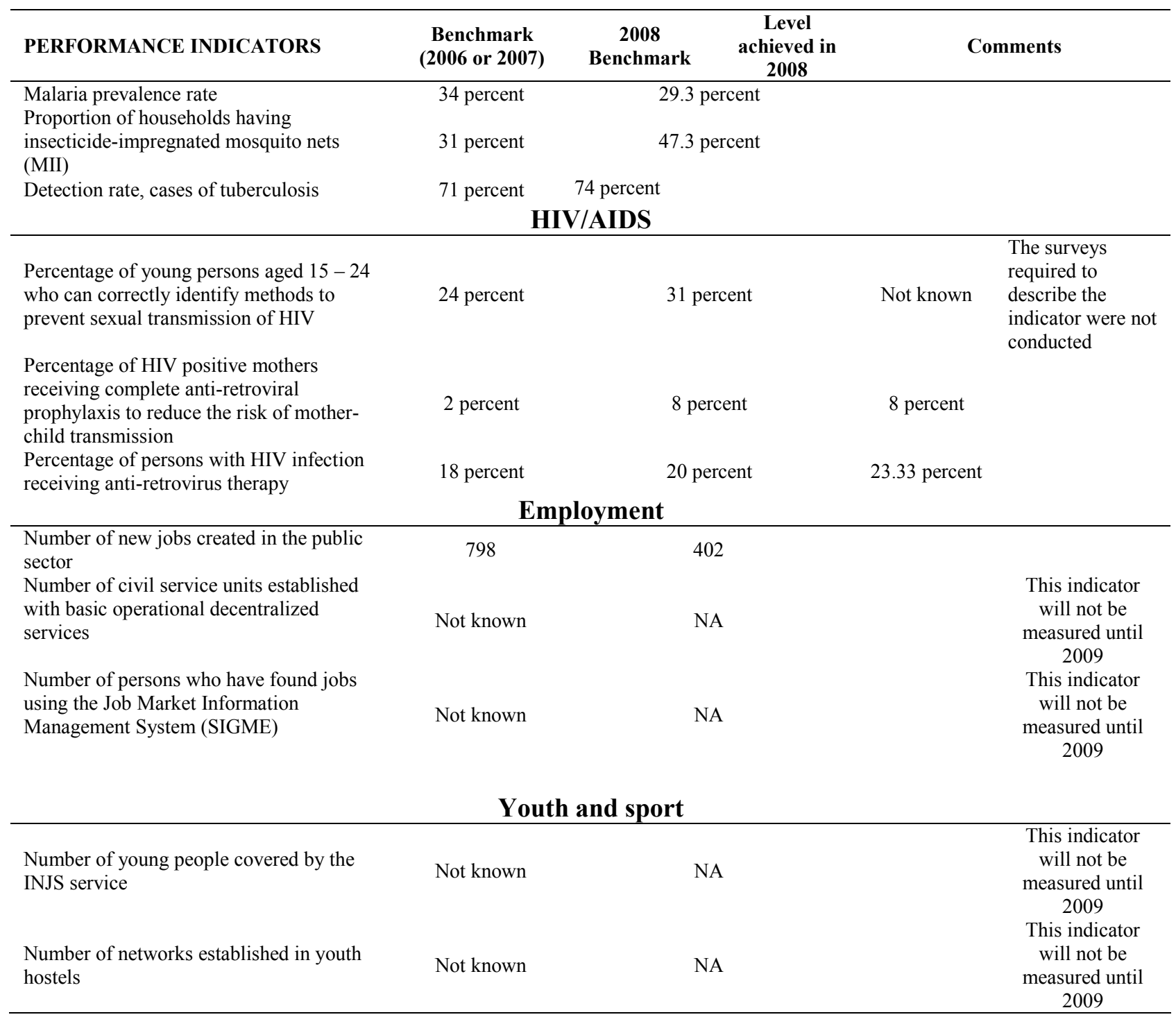


Annex 3. Development of key production activities

\begin{tabular}{|c|c|c|c|c|}
\hline Categories & 2005 & 2006 & 2007 & 2008* \\
\hline \multicolumn{5}{|l|}{ Cash crops } \\
\hline - Husk coffee (in tons) & 3,500 & 6,500 & 7,000 & 6,300 \\
\hline - Seed cotton (in tons) & 3,670 & 2,261 & 8,000 & 3,636 \\
\hline - Cotton fibers (in tons) & 2,878 & 1,541 & 950 & 3,360 \\
\hline - Tobacco & 177 & 142 & 146 & 150 \\
\hline \multicolumn{5}{|l|}{ Mining } \\
\hline - Diamonds (in carats) & 383,295 & 415,530 & 417,691 & 382,076 \\
\hline - Gold (in grams) & 10,400 & 10,293 & 12,506 & 34,000 \\
\hline \multicolumn{5}{|l|}{ Wood } \\
\hline - Logs $\left(\right.$ in $\left.\mathrm{m}^{3}\right)$ & 454,402 & 624,861 & 537,998 & 560,985 \\
\hline - Sawn timber and plywood (in $\mathrm{m}^{3}$ ) & 75,620 & 84,304 & 92,853 & 76,206 \\
\hline
\end{tabular}

Source: Technical Committee for Structural Adjustment (CTP-PAS).

N.B. The data for 2008 are estimates. The data from growing season $n-1 / n$ were not affected during year $n$.

Annex 4: Developments in the real GDP growth rate by sector

\begin{tabular}{|c|c|c|c|c|}
\hline Indicators & 2006 & 2007 & 2008 & 2009 \\
\hline Real GDP growth rate & 4.0 percent & 4.2 percent & 3.5 percent & 3.9 percent \\
\hline Primary & 4.3 percent & 2.6 percent & $\begin{array}{r}10.3 \\
\text { percent }\end{array}$ & $\begin{array}{r}10.6 \\
\text { percent }\end{array}$ \\
\hline - Agriculture & 2.9 percent & 5.4 percent & 2.4 percent & 30.67 \\
\hline - Livestock & 0.8 percent & 2.0 percent & 2.4 percent & 2.3 percent \\
\hline - Hunting and fishing & 1.0 percent & 1.8 percent & 1.3 percent & 1.7 percent \\
\hline - Forestry & 23.6 percent & $\begin{array}{r}-7.0 \\
\text { percent }\end{array}$ & 00.8 percent & -6.9 percent \\
\hline Secondary & 6.1 percent & 5.2 percent & $\begin{array}{r}10.3 \\
\text { percent }\end{array}$ & $\begin{array}{r}40.4 \\
\text { percent }\end{array}$ \\
\hline - Mining & 8.0 percent & 0.5 percent & $\begin{array}{r}-8.2 \\
\text { percent }\end{array}$ & 2.2 percent \\
\hline - Manufacturing & 6.5 percent & 7.0 percent & 2.5 percent & 3.0 percent \\
\hline - Water and electricity & 5.5 percent & 3.0 percent & $\begin{array}{r}-3.9 \\
\text { percent }\end{array}$ & 3.5 percent \\
\hline - Buildings and public works & 4.0 percent & 6.0 percent & 7.0 percent & 8.0 percent \\
\hline Tertiary & 3.8 percent & 7.6 percent & 5.0 percent & 4.4 percent \\
\hline - Transportation and telecommunications & 17.9 percent & 8.0 percent & 8.0 percent & 8.0 percent \\
\hline - Trade & 5.0 percent & 8.0 percent & 5.0 percent & 4.0 percent \\
\hline - Other commercial services & 3.0 percent & 8.0 percent & 8.0 percent & 5.0 percent \\
\hline - Non-commercial services & - 5.7 percent & 6.4 percent & 0.1 percent & 1.8 percent \\
\hline
\end{tabular}


Annex 5. Foreign trade by major group and product (in millions of CFAF)

\begin{tabular}{|c|c|c|c|c|c|c|}
\hline \multirow[b]{2}{*}{ Exports } & \multicolumn{2}{|c|}{2006} & \multicolumn{2}{|c|}{2007} & \multicolumn{2}{|c|}{2008} \\
\hline & Value & Structure & Value & Structure & Value & Structure \\
\hline Cattle & 7,279 & $\begin{array}{r}8.2 \\
\text { percent }\end{array}$ & 7,692 & $\begin{array}{r}8.2 \\
\text { percent }\end{array}$ & 8,119 & $\begin{array}{r}11.5 \\
\text { percent }\end{array}$ \\
\hline Cotton fiber & 836 & $\begin{array}{r}0.9 \\
\text { percent }\end{array}$ & 521 & $\begin{array}{r}0.6 \\
\text { percent }\end{array}$ & 634 & $\begin{array}{r}0.9 \\
\text { percent }\end{array}$ \\
\hline Commercial coffee & 1,042 & $\begin{array}{r}1.2 \\
\text { percent }\end{array}$ & 1,060 & $\begin{array}{r}1.1 \\
\text { percent }\end{array}$ & 1,146 & $\begin{array}{r}1.6 \\
\text { percent }\end{array}$ \\
\hline Tobacco & 73 & $\begin{array}{r}0.1 \\
\text { percent }\end{array}$ & 75 & $\begin{array}{r}0.1 \\
\text { percent }\end{array}$ & 81 & $\begin{array}{r}0.1 \\
\text { percent }\end{array}$ \\
\hline Diamonds & 32,666 & $\begin{array}{r}36.7 \\
\text { percent }\end{array}$ & 32,288 & $\begin{array}{r}34.3 \\
\text { percent }\end{array}$ & 22,198 & $\begin{array}{r}31.4 \\
\text { percent }\end{array}$ \\
\hline Logs & 29,031 & $\begin{array}{r}32.6 \\
\text { percent }\end{array}$ & 31,541 & $\begin{array}{r}33.5 \\
\text { percent }\end{array}$ & 23,445 & $\begin{array}{r}33.1 \\
\text { percent }\end{array}$ \\
\hline Other (sawn timber) & 17,063 & $\begin{array}{r}19.2 \\
\text { percent }\end{array}$ & 19,691 & $\begin{array}{r}20.9 \\
\text { percent }\end{array}$ & 15,368 & $\begin{array}{r}21.7 \\
\text { percent }\end{array}$ \\
\hline Other value & 8,300 & $\begin{array}{r}9.3 \\
\text { percent }\end{array}$ & 8,900 & $\begin{array}{r}9.5 \\
\text { percent }\end{array}$ & 7,900 & $\begin{array}{r}11.2 \\
\text { percent }\end{array}$ \\
\hline Gold & 100 & $\begin{array}{r}0.1 \\
\text { percent }\end{array}$ & 100 & $\begin{array}{r}0.1 \\
\text { percent }\end{array}$ & 216 & $\begin{array}{r}0.3 \\
\text { percent }\end{array}$ \\
\hline Enterprises & 100 & $\begin{array}{r}0.1 \\
\text { percent }\end{array}$ & 100 & $\begin{array}{r}0.1 \\
\text { percent }\end{array}$ & 105 & $\begin{array}{r}0.1 \\
\text { percent }\end{array}$ \\
\hline Other & 8,100 & $\begin{array}{r}9.1 \\
\text { percent }\end{array}$ & 8,700 & $\begin{array}{r}9.2 \\
\text { percent }\end{array}$ & 7,579 & $\begin{array}{r}10.7 \\
\text { percent }\end{array}$ \\
\hline Exports of goods & 89,011 & $\begin{array}{r}100.0 \\
\text { percent }\end{array}$ & 94,076 & $\begin{array}{r}100.0 \\
\text { percent }\end{array}$ & 70,772 & $\begin{array}{r}100.0 \\
\text { percent }\end{array}$ \\
\hline Service exports & 26,000 & & 28,100 & & 30,400 & \\
\hline $\begin{array}{c}\text { Total exports of goods and } \\
\text { Nonfactor services }\end{array}$ & 115,011 & & 122,176 & & 101,172 & \\
\hline \multicolumn{7}{|c|}{ Source: National statistical yearbook - ICASEES } \\
\hline & \multicolumn{2}{|c|}{2006} & \multicolumn{2}{|c|}{2007} & \multicolumn{2}{|c|}{2008} \\
\hline Imports & Value & Structure & Value & Structure & Value & Structure \\
\hline Petroleum products & 25,927 & $\begin{array}{r}25.2 \\
\text { percent } \\
9.9\end{array}$ & 29,044 & $\begin{array}{r}25.8 \\
\text { percent } \\
10.5\end{array}$ & 32,231 & $\begin{array}{r}26.6 \\
\text { percent } \\
11.2\end{array}$ \\
\hline Public sector & 10,200 & $\begin{array}{r}\text { percent } \\
17.4\end{array}$ & 11,800 & $\begin{array}{r}\text { percent } \\
17.1\end{array}$ & 13,500 & $\begin{array}{r}\text { percent } \\
14.4\end{array}$ \\
\hline BEAC notes & 17,900 & $\begin{array}{r}\text { percent } \\
47.5\end{array}$ & 19,300 & $\begin{array}{r}\text { percent } \\
46.7\end{array}$ & 17,463 & $\begin{array}{r}\text { percent } \\
47.8\end{array}$ \\
\hline Other & 48,900 & $\begin{array}{r}\text { percent } \\
\mathbf{1 0 0 . 0}\end{array}$ & 52,600 & $\begin{array}{r}\text { percent } \\
\mathbf{1 0 0 . 0}\end{array}$ & 57,807 & $\begin{array}{r}\text { percent } \\
\mathbf{1 0 0 . 0}\end{array}$ \\
\hline Imports of goods (FOB) & 102,927 & percent & 112,744 & percent & 121,001 & percent \\
\hline $\begin{array}{l}\text { Services } \\
\text { Total imports of goods and }\end{array}$ & 66,400 & & 71,800 & & 106,500 & \\
\hline nonfactor services & 169,327 & & 184,544 & & 227,501 & \\
\hline Balance of goods & $-13,916$ & & $-18,668$ & & $-50,229$ & \\
\hline Balance of services & $-40,400$ & & $-43,700$ & & $-76,100$ & \\
\hline Overall balance & $-54,316$ & & $-62,368$ & & 126,329 & \\
\hline
\end{tabular}

Source: National statistical yearbook - ICASEES 


\section{Annex 6. Matrix of PRSP Priority Measures}

Pillar 1. Restore security, consolidate peace, and prevent conflict

\begin{tabular}{|c|c|c|c|c|}
\hline Areas/sectors & Objectives/strategies & Priority activities programmed & Accomplishments during the first year & Comments \\
\hline \multirow{10}{*}{$\begin{array}{l}\text { Security, peace, } \\
\text { and justice }\end{array}$} & \multirow{2}{*}{$\begin{array}{l}\text { Strengthen material and human } \\
\text { capacities of the Defense and } \\
\text { Security Forces (FDS) }\end{array}$} & Training of the FDS & $\begin{array}{l}960 \text { FDS members received civic training; } 30 \text { officers } \\
\text { and } 30 \text { non-commissioned officers trained }\end{array}$ & \\
\hline & & $\begin{array}{l}\text { Provision of materials and equipment for the } \\
\text { FDS }\end{array}$ & Supply of 300 police uniforms & \\
\hline & $\begin{array}{l}\text { Reform, restructuring, territorial } \\
\text { reorganization, and participative, } \\
\text { coordinated transformation of the } \\
\text { security sector }\end{array}$ & $\begin{array}{l}\text { Construction and rehabilitation of barracks } \\
\text { and premises for the FDS }\end{array}$ & & \\
\hline & \multirow{7}{*}{$\begin{array}{l}\text { Subregional security, action } \\
\text { against proliferation of light and } \\
\text { low-caliber weapons }\end{array}$} & Light weapons reduction & $\begin{array}{l}\text { Destruction in August } 2008 \text { of } 429 \text { weapons collected } \\
\text { in connection with the PRAC }\end{array}$ & \\
\hline & & Dismantling of illegal barriers & 25 illegal barriers dismantled & \\
\hline & & Border patrols & & \\
\hline & & $\begin{array}{l}\text { Subregional cooperation in the area of } \\
\text { security }\end{array}$ & $\begin{array}{l}\text { The C.A.R.'s admission in June } 2008 \text { to the UN } \\
\text { Action plan for the consolidation of peace }\end{array}$ & \\
\hline & & Disarmament of veterans & & \\
\hline & & Demobilization and re-integration of veterans & $\begin{array}{l}4,590 \text { veterans were demobilized and re-integrated in } \\
\text { the PRAC framework }\end{array}$ & \\
\hline & & Community support & $\begin{array}{l}12 \text { awareness sessions organized for local populations } \\
\text { in areas where garrisons are being restored } \\
\text { Open houses organized }\end{array}$ & \\
\hline
\end{tabular}




\begin{tabular}{llll}
\hline Areas/sectors & \multicolumn{1}{c}{ Objectives/strategies } & \multicolumn{1}{c}{ Priority activities programmed } & Accomplishments during the first year \\
\hline & Education, development of the & Comments \\
FDS and restoration of confidence & $\begin{array}{l}\text { Strengthening of the legal and judicial } \\
\text { framework (implementation of the Code of } \\
\text { military justice and capacity building for the } \\
\text { Permanent Military Court }\end{array}$ \\
\cline { 2 - 4 } & Strengthening of the FDS supervision bodies & \\
\cline { 2 - 4 } & Awareness activities for the public and FDS & $\begin{array}{l}12 \text { awareness sessions in areas where organized } \\
\text { garrisons are being restored } \\
\text { Training of neighborhood and village leaders to } \\
\text { develop their skills in Bozoum, Bossangao, Kaga } \\
\text { Bandoro, and Sibut }\end{array}$ \\
\hline
\end{tabular}


Pillar 2. Promote governance and the rule of law

\begin{tabular}{|c|c|c|c|c|}
\hline Areas/sectors & Objectives/strategies & Priority activities programmed & Accomplishments during the first year & Comments \\
\hline \multirow[t]{7}{*}{ Governance } & \multirow{4}{*}{$\begin{array}{l}\text { Promotion of the democratic } \\
\text { culture }\end{array}$} & $\begin{array}{l}\text { Implementation of the support plan for } \\
\text { the National Assembly, Constitutional } \\
\text { Court, High Council on } \\
\text { Communication, and CSADN }\end{array}$ & & \\
\hline & & $\begin{array}{l}\text { Reorganization and capacity building } \\
\text { for civil society }\end{array}$ & & \\
\hline & & $\begin{array}{l}\text { Capacity building for the media and } \\
\text { communication on democratic culture }\end{array}$ & $\begin{array}{l}\text { Establishment of an Information Sciences Department at the } \\
\text { University of Bangui }\end{array}$ & \\
\hline & & $\begin{array}{l}\text { Promotion of an ongoing political and } \\
\text { social dialog }\end{array}$ & $\begin{array}{l}\text { Establishment of an inclusive political dialog (DPI) organizing } \\
\text { committee on June 8, } 2008 \text { and implementation of the social dialog } \\
\text { with unions }\end{array}$ & \\
\hline & \multirow{3}{*}{$\begin{array}{l}\text { Promotion of human rights } \\
\text { compliance }\end{array}$} & $\begin{array}{l}\text { Capacity building for national units } \\
\text { responsible for human rights and } \\
\text { governance }\end{array}$ & $\begin{array}{l}\text { Training of professionals responsible for promoting various services } \\
\text { in the High Commission for Human Rights }\end{array}$ & \\
\hline & & $\begin{array}{l}\text { Preparation and implementation of a } \\
\text { national action plan to promote and } \\
\text { protect human rights }\end{array}$ & $\begin{array}{l}\text { Adoption of a draft text establishing a national committee responsible } \\
\text { for preparing a national action plan }\end{array}$ & \\
\hline & & $\begin{array}{l}\text { New impetus for the National } \\
\text { Commission on Human Rights and } \\
\text { establishment of a pool of human rights } \\
\text { specialists }\end{array}$ & $\begin{array}{l}10 \text { professionals from the High Commission for Human rights have } \\
\text { been trained }\end{array}$ & \\
\hline \multirow[t]{4}{*}{ Governance } & \multirow{4}{*}{$\begin{array}{l}\text { Improvement and } \\
\text { optimization of general } \\
\text { government }\end{array}$} & $\begin{array}{l}\text { Implementation of a new organic } \\
\text { framework for general government }\end{array}$ & Completion of audits in seven ministries & \\
\hline & & $\begin{array}{l}\text { Revision of the general civil service } \\
\text { by-laws }\end{array}$ & Adoption of the revised general civil serviced by-laws & \\
\hline & & $\begin{array}{l}\text { Implementation of a scheme for } \\
\text { redeployment of services within the } \\
\text { country }\end{array}$ & & \\
\hline & & $\begin{array}{l}\text { Forward-looking study for Central } \\
\text { Africa } 2040\end{array}$ & & \\
\hline
\end{tabular}




\begin{tabular}{|c|c|c|c|c|}
\hline Areas/sectors & Objectives/strategies & Priority activities programmed & Accomplishments during the first year & Comments \\
\hline & Strengthening the rule of law & $\begin{array}{l}\text { Capacity building for justice personnel } \\
\text { and auxiliary officers }\end{array}$ & $\begin{array}{l}42 \text { magistrates, } 5 \text { bailiffs, } 4 \text { women administrators and } \\
12 \text { female prison guards trained }\end{array}$ & \\
\hline & \multirow{4}{*}{$\begin{array}{l}\text { Enhancement of fiscal } \\
\text { management }\end{array}$} & $\begin{array}{l}\text { Drafting and implementation of guides } \\
\text { and manuals of procedure for } \\
\text { expenditure control and execution }\end{array}$ & $\begin{array}{l}\text { Implementation of a computer system for the General Budget and } \\
\text { Treasury Directorate }\end{array}$ & \\
\hline & & $\begin{array}{l}\text { Updating of the fiscal and taxation } \\
\text { schemes }\end{array}$ & & \\
\hline & & $\begin{array}{l}\text { Implementation of an integrated fiscal } \\
\text { management system }\end{array}$ & Establishment of a liquidity monitoring committee & \\
\hline & & $\begin{array}{l}\text { Establishment of a transparent } \\
\text { government contracting framework }\end{array}$ & $\begin{array}{l}\text { Adoption of the law in respect of the government contracting code } \\
\text { Establishment of the government contracting regulation authority }\end{array}$ & \\
\hline & \multirow[b]{2}{*}{$\begin{array}{l}\text { Provision of new impetus for } \\
\text { the decentralization process }\end{array}$} & $\begin{array}{l}\text { Strengthening of the institutions } \\
\text { responsible for decentralization and the } \\
\text { capacities of the local and } \\
\text { administrative authorities }\end{array}$ & & \\
\hline & & $\begin{array}{l}\text { Conduct of baseline studies to enhance } \\
\text { knowledge of the feasibility conditions } \\
\text { for decentralization }\end{array}$ & & \\
\hline
\end{tabular}




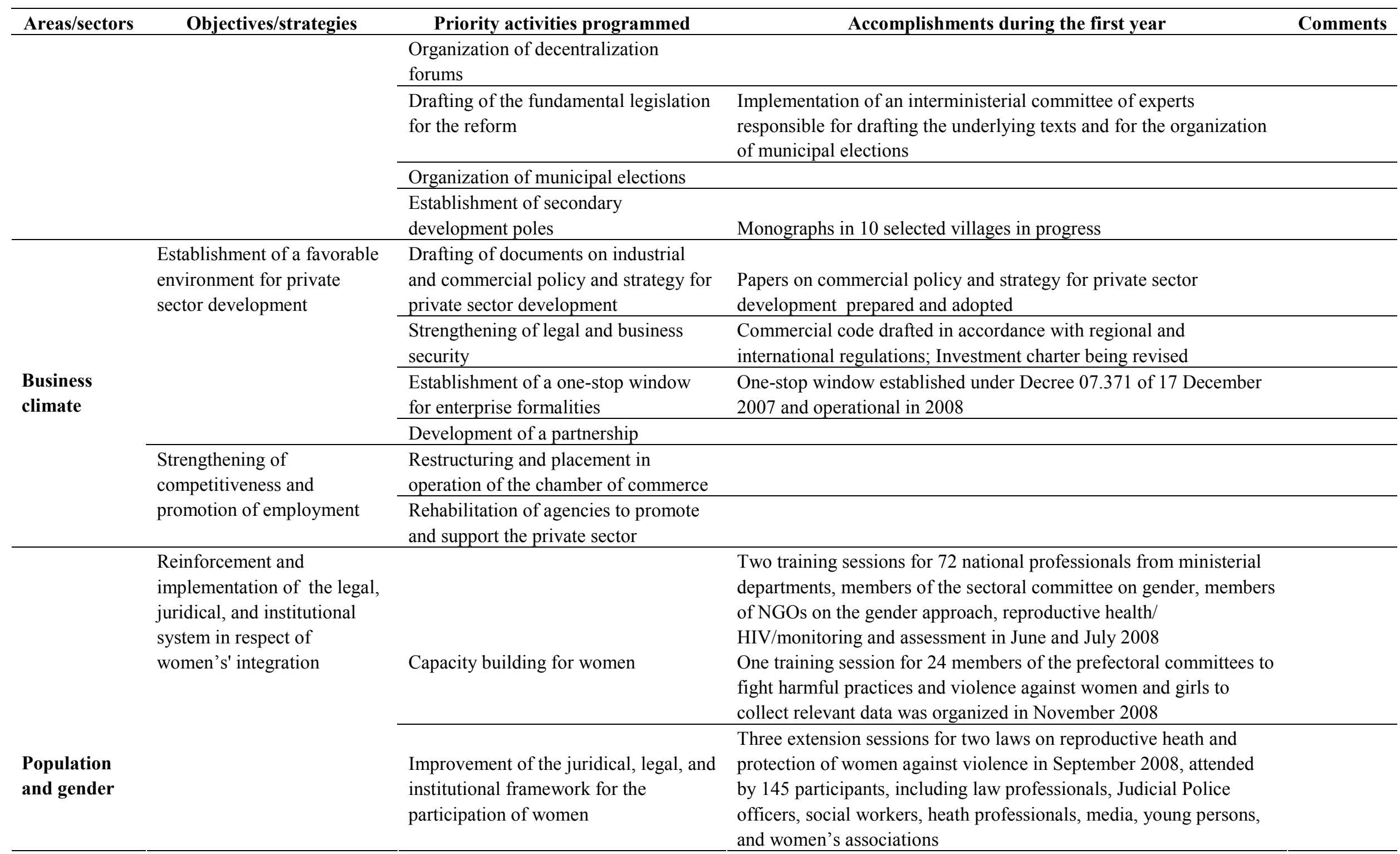




\begin{tabular}{|c|c|c|c|c|}
\hline Areas/sectors & Objectives/strategies & Priority activities programmed & Accomplishments during the first year & Comments \\
\hline & & & $\begin{array}{l}\text { Preliminary validation of a draft initial report of the Convention on } \\
\text { elimination of all forms of discrimination against women in January } \\
2008 \text {. The process of recruiting an international consultant is in } \\
\text { progress and should be completed in January } 2009\end{array}$ & \\
\hline & & & $\begin{array}{l}\text { Establishment of a sectoral committee on Gender and Poverty } \\
\text { Reduction under Decree } 014 \text { of May 14, } 2008 \text { and of the Permanent } \\
\text { Technical Secretariat under Decree } 043 \text { of November 5, } 2008 \text { of the } \\
\text { Prime Minister in preparation for the sectoral round table on gender } \\
\text { and PRSP implementation monitoring }\end{array}$ & \\
\hline & & & $\begin{array}{l}\text { Rehabilitation in progress of one building in Birao, in the amount of } \\
\text { CFAF 7,178,800 by The United Nations Mission in the C.A.R. } \\
\text { (MINURCAT) to house the training center for } 30 \text { female assistants in } \\
\text { connection with the gender integration project to enhance security for } \\
\text { women in areas affected by the conflict }\end{array}$ & \\
\hline & & $\begin{array}{l}\text { Involvement of women in conflict } \\
\text { resolution pursuant to Resolution } 1325\end{array}$ & $\begin{array}{l}\text { Purchase of uniforms and other items (December 2008) for the } \\
\text { training of } 30 \text { auxiliary police women in the amount of } \\
\text { CFAF } 10,500,000 \text { financed by MINURCAT }\end{array}$ & \\
\hline & & & $\begin{array}{l}\text { Recruitment of } 20 \text { women police officers and gendarmes for the } \\
\text { training of auxiliary women }\end{array}$ & \\
\hline
\end{tabular}


Pillar 3. Rebuild and diversify the economy

\begin{tabular}{|c|c|c|c|c|}
\hline Areas/sectors & Objectives/strategies & Priority activities programmed & Accomplishments during the first year & Comments \\
\hline \multirow{9}{*}{$\begin{array}{l}\text { Rural } \\
\text { development }\end{array}$} & \multirow{4}{*}{$\begin{array}{l}\text { Organization, } \\
\text { management, and } \\
\text { accountability of rural } \\
\text { players }\end{array}$} & Organization of rural development forums & $\begin{array}{l}\text { With World Bank financing (CFAF } 125 \text { million), rural } \\
\text { development forums were organized in January } 2008 \text { with } \\
625 \text { participants }\end{array}$ & $\begin{array}{l}\text { Report } \\
\text { available }\end{array}$ \\
\hline & & $\begin{array}{l}\text { Capacity building for the chamber of agriculture } \\
\text { and producers' organizations }\end{array}$ & & \\
\hline & & $\begin{array}{l}\text { Rehabilitation of professional agencies providing } \\
\text { technical support and training in rural areas }\end{array}$ & & \\
\hline & & $\begin{array}{l}\text { Resumption of research, supervision, and training } \\
\text { programs }\end{array}$ & $\begin{array}{l}\text { The Food and Agriculture Organization of the United } \\
\text { Nations (FAO) supported agronomic research in the area } \\
\text { of seed production, in the amount of CFAF } 255 \text { million }\end{array}$ & $\begin{array}{l}\text { Technical } \\
\text { cooperation } \\
\text { project }\end{array}$ \\
\hline & \multirow{5}{*}{$\begin{array}{l}\text { Increase in animal and } \\
\text { plant productivity and } \\
\text { output }\end{array}$} & $\begin{array}{l}\text { Resumption of food production; seed } \\
\text { multiplication and dissemination }\end{array}$ & $\begin{array}{l}\text { Supply of agricultural inputs and small equipment to } \\
8,500 \text { agricultural households; distribution of } 16,000 \\
\text { horticulture kits; implementation of } 224 \text { ha of seed } \\
\text { multiplication parcels; establishment of strategic seed } \\
\text { stocks for food crops; and farming equipment for } \\
3,000 \text { households }\end{array}$ & $\begin{array}{l}\text { FAO } \\
\text { Humanitarian } \\
\text { project: FAO, } \\
\text { CFAF } 2.7 \text { billio } \\
\text { n; and China, } \\
\text { US } \$ 2.5 \text { million }\end{array}$ \\
\hline & & $\begin{array}{l}\text { Development of cash crops (cotton, coffee, oil } \\
\text { palm, sugar cane, and tobacco) }\end{array}$ & $\begin{array}{l}\text { Implementation of 5,000 animal traction lines to produce } \\
\text { cotton by Japan in the amount of US } \$ 1,364,096\end{array}$ & \\
\hline & & $\begin{array}{l}\text { Resumption of short-cycle livestock activities in } \\
\text { urban, suburban, and rural areas }\end{array}$ & $\begin{array}{l}\text { Implementation of } 104 \text { production units as tests and } \\
\text { preliminary assistance } \\
\text { Financing of production units for eggs, broilers, pigs, } \\
\text { goats, etc. }\end{array}$ & $\begin{array}{l}\text { Humanitarian } \\
\text { projects }(\text { cost: } \\
\text { US } \$ 1,079,500)\end{array}$ \\
\hline & & $\begin{array}{l}\text { Development of traditional nomadic, sedentary } \\
\text { livestock facilities and rehabilitation of } \\
\text { trypanotolerant livestock activities }\end{array}$ & & \\
\hline & & $\begin{array}{l}\text { Development of irrigate growing systems (in the } \\
\text { off seasons) in the lowlands }\end{array}$ & & \\
\hline
\end{tabular}




\begin{tabular}{|c|c|c|c|c|}
\hline Areas/sectors & Objectives/strategies & $\begin{array}{l}\text { Priority activities programmed } \\
\end{array}$ & Accomplishments during the first year & Comments \\
\hline & \multirow[t]{2}{*}{$\begin{array}{l}\text { Opening up of rural areas } \\
\text { and reducing factors in } \\
\text { vulnerability }\end{array}$} & $\begin{array}{l}\text { Rehabilitation and maintenance of } 2,000 \mathrm{~km} \text { of } \\
\text { rural roads and engineering works in production } \\
\text { areas }\end{array}$ & $\begin{array}{l}206 \mathrm{~km} \text { of rural roads rehabilitated/built } \\
52 \text { engineering works rehabilitated/built }\end{array}$ & \\
\hline & & $\begin{array}{l}\text { Development of infrastructures for processing, } \\
\text { storage, intermediary transport facilities, } \\
\text { promotion of agricultural product processing, and } \\
\text { development of marketing networks }\end{array}$ & & \\
\hline & \multirow{2}{*}{$\begin{array}{l}\text { Institutional capacity } \\
\text { building for the ministry } \\
\text { of rural development } \\
\text { (planning, statistics, } \\
\text { resource management, } \\
\text { research, advisory } \\
\text { support, training, and } \\
\text { communications) }\end{array}$} & $\begin{array}{l}\text { Operational and human resource capacity } \\
\text { building for the services of the ministry of rural } \\
\text { development responsible for statistics, planning, } \\
\text { monitoring and assessment, protection, and } \\
\text { phytosanitary and zoosanitary control }\end{array}$ & $\begin{array}{l}\text { Capacity building for the Planning Directorate in the } \\
\text { computer area in the amount of CFAF } 4,600,000 \text {, and } \\
\text { computer equipment for the Statistics Directorate in the } \\
\text { amount of CFAF } 81,906,735\end{array}$ & $\begin{array}{l}\text { With a } \\
\text { contribution } \\
\text { from AfDB }\end{array}$ \\
\hline & & $\begin{array}{l}\text { Capacity building for the rural activity finance } \\
\text { scheme (agro-pastoral development fund), } \\
\text { national equipment office (ONM) }\end{array}$ & $\begin{array}{l}\text { Implementation of the Agricultural and Pastoral Fund } \\
\text { Development (FDAP) and the National Office for } \\
\text { Agricultural and Pastoral Equipment (ONMAP) with two } \\
\text { laws. }\end{array}$ & \\
\hline \multirow[t]{4}{*}{ Mining } & \multirow{4}{*}{$\begin{array}{l}\text { Enhancement of the } \\
\text { legal, institutional, and } \\
\text { fiscal framework of the } \\
\text { sector }\end{array}$} & Strengthening and updating of the Mining code & $\begin{array}{l}\text { Audit of the mining sector completed } \\
\text { Draft Mining code revised }\end{array}$ & \\
\hline & & $\begin{array}{l}\text { Establishment of a tax scheme to promote } \\
\text { development of mining regions }\end{array}$ & $\begin{array}{l}\text { The C.A.R.'s membership in the Mining Sector } \\
\text { Transparency Initiative (ITIE) }\end{array}$ & \\
\hline & & Implementation of a reliable geological database & $\begin{array}{l}\text { An ad hoc committee has been established to draft the } \\
\text { texts to create a geological office }\end{array}$ & \\
\hline & & $\begin{array}{l}\text { Preparation and implementation of standard } \\
\text { specifications for mining companies }\end{array}$ & & $\begin{array}{l}\text { Integrated } \\
\text { project with } \\
\text { revision of the } \\
\text { code }\end{array}$ \\
\hline
\end{tabular}

Strengthening of transparency in sector management
Strengthening of accountability in connection with the Kimberley Process
Sensitize small-scale miners from Lobaye and Mambéré-

Kadéi on the use of production diamond specifications, expert appraisals, and evaluations 


\begin{tabular}{|c|c|c|c|c|}
\hline Areas/sectors & Objectives/strategies & Priority activities programmed & Accomplishments during the first year & Comments \\
\hline & & \multicolumn{3}{|l|}{$\begin{array}{l}\text { Strengthening of the mining corps with } \\
\text { equipment }\end{array}$} \\
\hline & & Joining the ITIE & $\begin{array}{l}\text { Establishment, under Decree } 08.260 \text { of July } 18,2000 \text {, of } \\
\text { an institutional scheme for the ITIE in the C.A.R., which } \\
\text { already has status as a candidate country }\end{array}$ & \\
\hline & & \multicolumn{3}{|l|}{ Establishment of a mining police force } \\
\hline & \multirow{3}{*}{$\begin{array}{l}\text { Increase in mining } \\
\text { production and } \\
\text { improvement of income } \\
\text { for mining area } \\
\text { populations }\end{array}$} & $\begin{array}{l}\text { Resumption of Bangui International Diamond } \\
\text { Exchange operations }\end{array}$ & $\begin{array}{l}\text { Updating of texts establishing the Bangui Diamond } \\
\text { Exchange }\end{array}$ & \\
\hline & & $\begin{array}{l}\text { Strengthening of small-scale mining associations } \\
\text { and cooperatives }\end{array}$ & & \\
\hline & & $\begin{array}{l}\text { Development of industrial production in small } \\
\text { and medium-scale industries and enterprises in } \\
\text { the area of mining }\end{array}$ & & \\
\hline \multirow[t]{6}{*}{$\begin{array}{l}\text { Transportatio } \\
\text { n and } \\
\text { infrastructure }\end{array}$} & \multirow[t]{3}{*}{$\begin{array}{l}\text { Strengthening of the } \\
\text { institutional framework } \\
\text { for management of } \\
\text { transportation } \\
\text { infrastructures }\end{array}$} & $\begin{array}{l}\text { Capacity building for transportation management } \\
\text { agencies (Road maintenance fund, Water } \\
\text { transport development fund, National equipment } \\
\text { office, and National building and public works } \\
\text { office (ASECNA) }\end{array}$ & $\begin{array}{l}\text { Revision of the BTP laboratory by-laws in progress; } \\
\text { training of its staff in the amount of CFAF } 80 \text { million; and } \\
\text { acquisition of surveying and quality control equipment in } \\
\text { the amount of CFAF } 494 \text { million. } \\
\text { Equipment for the National Materials Office equivalent to } \\
\text { CFAF } 1.5 \text { billion by the European Union }\end{array}$ & \\
\hline & & $\begin{array}{l}\text { Making the transportation infrastructure } \\
\text { management system operational }\end{array}$ & & \\
\hline & & $\begin{array}{l}\text { Preliminary feasibility study on domestic airports } \\
\text { and the meteorological system }\end{array}$ & & \\
\hline & \multirow[t]{3}{*}{$\begin{array}{l}\text { Rehabilitation, } \\
\text { construction, and } \\
\text { optimization of } \\
\text { transportation } \\
\text { infrastructures }\end{array}$} & $\begin{array}{l}\text { Rehabilitation and maintenance of transportation } \\
\text { infrastructures (rural roads, unpaved roads, paved } \\
\text { roads, and engineering works) }\end{array}$ & $\begin{array}{l}\text { Rehabilitation of four major roads, specifically: Berbérati- } \\
\text { Bayanga }(232 \mathrm{Km}) \text {, Sibut-Kagabandoro-Ndélé }(465 \mathrm{Km}) \text {, } \\
\text { Sibut-Bambari }(200 \mathrm{Km}) \text {, Bossembélé- Bossangoa- } \\
\text { Benzambé }(195 \mathrm{Km}) \text {, and Mbaïki-Boda }(85 \mathrm{Km})\end{array}$ & \\
\hline & & Construction of bus stations & $\begin{array}{l}\text { Construction and rehabilitation of bus stations in Bangui, } \\
\text { Bossangoa, and Berbérati }\end{array}$ & \\
\hline & & $\begin{array}{l}\text { Rehabilitation of the nine secondary airports and } \\
\text { the Bangui Airport }\end{array}$ & VIP room at the Bangui airport refurbished by ASECNA & \\
\hline
\end{tabular}




\begin{tabular}{|c|c|c|c|c|}
\hline Areas/sectors & Objectives/strategies & Priority activities programmed & Accomplishments during the first year & Comments \\
\hline & & $\begin{array}{l}\text { Raising of the Berberati Airport to international } \\
\text { standards }\end{array}$ & & \\
\hline & $\begin{array}{l}\text { Strengthening of the } \\
\text { institutional framework } \\
\text { for urban planning and } \\
\text { development }\end{array}$ & $\begin{array}{l}\text { Institutional and logistical support for the land } \\
\text { registry, urban development, and housing } \\
\text { services }\end{array}$ & & \\
\hline & $\begin{array}{l}\text { Rehabilitation, } \\
\text { construction, and }\end{array}$ & $\begin{array}{l}\text { Rehabilitation, drainage, and de-isolation of } \\
\text { unhealthy and inaccessible neighborhoods }\end{array}$ & & \\
\hline & servicing of urban areas & $\begin{array}{l}\text { Servicing of lots and establishment of new } \\
\text { parcels }\end{array}$ & & \\
\hline & & Construction of low-cost housing & & \\
\hline & & $\begin{array}{l}\text { Updating of urban cartography for Bangui and } 16 \\
\text { provincial cities }\end{array}$ & & \\
\hline & & $\begin{array}{l}\text { Rehabilitation and construction of public } \\
\text { buildings }\end{array}$ & & \\
\hline \multirow[t]{5}{*}{ Forestry } & \multirow{3}{*}{$\begin{array}{l}\text { Increased contribution } \\
\text { from the forestry sector } \\
\text { to national wealth and } \\
\text { state revenue }\end{array}$} & $\begin{array}{l}\text { Promotion and development of small and } \\
\text { medium-scale enterprises and industries and } \\
\text { implementation of effective processing units }\end{array}$ & & \\
\hline & & $\begin{array}{l}\text { Ownership of the populations in management of } \\
\text { forestry and fauna taxes paid to the communes }\end{array}$ & $\begin{array}{l}\text { Establishment of an interministerial technical committee } \\
\text { comprised of representatives from the ministries and the } \\
\text { local populations to manage forestry and fauna taxes } \\
\text { Opening of a standby account with the BEAC to manage } \\
\text { the common forestry tax }\end{array}$ & \\
\hline & & $\begin{array}{l}\text { Breeding practices in game farms to increase } \\
\text { state revenue }\end{array}$ & & \\
\hline & \multirow[t]{2}{*}{$\begin{array}{l}\text { Enhanced transparency in } \\
\text { forestry and fauna } \\
\text { resource management }\end{array}$} & $\begin{array}{l}\text { Strengthening of management of the special } \\
\text { allocation account for forestry and tourism } \\
\text { development (CAS-DFT) }\end{array}$ & & \\
\hline & & $\begin{array}{l}\text { Capacity building in monitoring and control in } \\
\text { the forestry and fauna sector }\end{array}$ & $\begin{array}{l}\text { Establishment of mobile intervention and inspection } \\
\text { brigades } \\
\text { Appointment of border control inspectors in July } 2008\end{array}$ & \\
\hline
\end{tabular}




\begin{tabular}{|c|c|c|c|c|}
\hline Areas/sectors & Objectives/strategies & Priority activities programmed & Accomplishments during the first year & Comments \\
\hline \multirow[t]{12}{*}{ Energy } & \multirow[t]{2}{*}{$\begin{array}{l}\text { Implementation of energy } \\
\text { information system }\end{array}$} & Capacity building in the sector & $\begin{array}{l}\text { Training of four professionals to use GIS and computer } \\
\text { equipment }\end{array}$ & \\
\hline & & Establishment of an energy database & & \\
\hline & \multirow{7}{*}{$\begin{array}{l}\text { Guarantee of power } \\
\text { supply for urban and } \\
\text { suburban centers }\end{array}$} & $\begin{array}{l}\text { Rehabilitation of the production infrastructures in } \\
\text { Boali } 1 \text { and 2, and doubling of its capacity }\end{array}$ & & \\
\hline & & $\begin{array}{l}\text { Installation of a plant at the foot of the Boali } 3 \\
\text { Dam }\end{array}$ & & \\
\hline & & $\begin{array}{l}\text { Rehabilitation and expansion of the distribution } \\
\text { network and transportation lines }\end{array}$ & & \\
\hline & & Capacity increase for ENERCA Stations A and B & & \\
\hline & & Electrification of the city of Bria & & \\
\hline & & $\begin{array}{l}\text { Replacement of hydroelectric plants with thermal } \\
\text { plants in the secondary centers of Bambari, } \\
\text { Berberati, Carnot, Boda, and Mbaïki }\end{array}$ & & \\
\hline & & $\begin{array}{l}\text { Connection of the city of Zongo (Democratic } \\
\text { Republic of the Congo) to the ENERCA network }\end{array}$ & & \\
\hline & \multirow[t]{3}{*}{$\begin{array}{l}\text { Guarantee of } \\
\text { hydrocarbon supplies for } \\
\text { urban and rural areas }\end{array}$} & $\begin{array}{l}\text { Rehabilitation of the petroleum product price } \\
\text { structure audit }\end{array}$ & $\begin{array}{l}\text { Adoption by the National Assembly of a draft law } \\
\text { establishing the petroleum product price regulation and } \\
\text { stabilization agency }\end{array}$ & \\
\hline & & $\begin{array}{l}\text { Establishment of storage capacities in Bocaranga } \\
\text { and Bria }\end{array}$ & & \\
\hline & & $\begin{array}{l}\text { Rehabilitation of the study for Sudan and Chad to } \\
\text { supply the C.A.R. }\end{array}$ & & \\
\hline \multirow{3}{*}{$\begin{array}{l}\text { Water and } \\
\text { sanitation }\end{array}$} & \multirow{3}{*}{$\begin{array}{l}\text { Strengthening of the } \\
\text { institutional and } \\
\text { regulatory framework, } \\
\text { and water management } \\
\text { and planning capacities }\end{array}$} & Support for water management agencies & $\begin{array}{l}\text { Establishment of a regulatory agency for the sector and } \\
\text { rehabilitation of a National Water and Sanitation Agency }\end{array}$ & \\
\hline & & $\begin{array}{l}\text { Restructuring of the water distribution company } \\
\text { (SODECA) }\end{array}$ & & \\
\hline & & $\begin{array}{l}\text { Strengthening of technical, material, and human } \\
\text { capacities }\end{array}$ & $\begin{array}{l}\text { Training of } 132 \text { masons in technical construction of } \\
\text { household latrines } \\
\text { Hygiene and sanitation training of } 28 \text { leaders and } \\
\text { instructors }\end{array}$ & \\
\hline
\end{tabular}




\begin{tabular}{|c|c|c|c|c|}
\hline Areas/sectors & Objectives/strategies & Priority activities programmed & Accomplishments during the first year & Comments \\
\hline & & & $\begin{array}{l}\text { Training of } 44 \text { management committee members from } \\
\text { heath centers }\end{array}$ & \\
\hline & & $\begin{array}{l}\text { Development of a population information, } \\
\text { communication, and education program in the } \\
\text { area of water and sanitation }\end{array}$ & & \\
\hline & & $\begin{array}{l}\text { Completion of a feasibility study on the } \\
\text { sanitation and drinking water system and a water } \\
\text { resource management action plan }\end{array}$ & $\begin{array}{l}\text { Launch of a feasibility study for the national water and } \\
\text { sanitation fund }\end{array}$ & \\
\hline & $\begin{array}{l}\text { Rehabilitation and } \\
\text { construction of supply } \\
\text { and sanitation works }\end{array}$ & $\begin{array}{l}\text { Rehabilitation of water supply equipment, } \\
\text { maintenance of existing facilities, and expansion } \\
\text { of the drinking water system }\end{array}$ & $\begin{array}{l}\text { Construction of } 144 \text { bore holes and } 15 \text { sand filters } \\
\text { Rehabilitation of } 280 \text { boreholes and } 184 \text { wells } \\
\text { Development of } 21 \text { springs }\end{array}$ & \\
\hline & & $\begin{array}{l}\text { Completion of sanitation works in urban and } \\
\text { rural areas }\end{array}$ & $\begin{array}{l}\text { Improvement of 1,630 traditional latrines and } \\
66 \text { ventilated pit latrines } \\
\text { Construction of } 4 \text { incinerators in health units } \\
\text { Distribution of } 15,615 \text { hygiene kits (soap, buckets, basins, } \\
\text { and kettles) }\end{array}$ & \\
\hline \multirow[t]{4}{*}{$\begin{array}{l}\text { Arts and } \\
\text { culture }\end{array}$} & $\begin{array}{l}\text { Organization and } \\
\text { promotion of the art } \\
\text { market }\end{array}$ & $\begin{array}{l}\text { Establishment of six cultural centers (art } \\
\text { markets), four of which in Bangui and two in the } \\
\text { provinces (Berberati and Bambari) }\end{array}$ & & \\
\hline & $\begin{array}{l}\text { Promotion of an } \\
\text { environment to foster } \\
\text { development of cultural } \\
\text { enterprises and industries }\end{array}$ & $\begin{array}{l}\text { Establishment of an audiovisual equipment } \\
\text { center and recording and production studio in } \\
\text { Bangui }\end{array}$ & & \\
\hline & $\begin{array}{l}\text { Upgrading of cultural, } \\
\text { natural, and combined } \\
\text { resources in several } \\
\text { forms }\end{array}$ & $\begin{array}{l}\text { Studies to document } 10 \text { sites on the C.A.R.'s } \\
\text { indicative list and to establish management plans } \\
\text { for them in accordance with the } 1972 \text { UNESCO } \\
\text { guidelines }\end{array}$ & & \\
\hline & & $\begin{array}{l}\text { Technical support for implementation of site } \\
\text { management plans according to UNESCO } \\
\text { specifications and guidelines }\end{array}$ & & \\
\hline
\end{tabular}




\begin{tabular}{|c|c|c|c|c|}
\hline Areas/sectors & Objectives/strategies & Priority activities programmed & Accomplishments during the first year & Comments \\
\hline \multirow[t]{9}{*}{ Tourism } & \multirow{3}{*}{$\begin{array}{l}\text { Promotion of a favorable } \\
\text { environment for the } \\
\text { development of tourism }\end{array}$} & $\begin{array}{l}\text { Preparation and implementation of a code of } \\
\text { ethics and the tourism investment charter }\end{array}$ & & \\
\hline & & $\begin{array}{l}\text { Training of personnel working in lodging } \\
\text { establishments, restaurants, leisure facilities, } \\
\text { travel agencies, tourism guides, and taxi and bus } \\
\text { drivers to enhance the quality of services }\end{array}$ & $\begin{array}{l}\text { Hospitality and culinary arts training for } 50 \text { staff from } \\
\text { Hotel Boali Chutes, Hotel Azimut, and the Restaurant } \\
\text { Méditerranée } \\
20 \text { further persons are being trained in connection with the } \\
\text { launch of taxidermy activities }\end{array}$ & \\
\hline & & $\begin{array}{l}\text { Promotion of the establishment of a combined } \\
\text { committee for sustainable trans-border tourism } \\
\text { resource management }\end{array}$ & & \\
\hline & \multirow[t]{6}{*}{$\begin{array}{l}\text { Development of tourism } \\
\text { resources }\end{array}$} & $\begin{array}{l}\text { Renovation of } 200 \text { restaurant units and } 800 \\
\text { rooms in traditional inns }\end{array}$ & & \\
\hline & & $\begin{array}{l}\text { Planning of natural tourist attractions in Bangui } \\
\text { and its vicinity }\end{array}$ & $\begin{array}{l}\text { Development of an occupation plan for the Bas-Oubangui } \\
\text { hills }\end{array}$ & \\
\hline & & $\begin{array}{l}\text { Development of the Dzanga-Sangha and Mbaéré } \\
\text { Bodingué reserves }\end{array}$ & $\begin{array}{l}\text { Launch of a request for tenders for management of the } \\
\text { Doli-Lodge in Bayanga }\end{array}$ & \\
\hline & & $\begin{array}{l}\text { Development of the Bangassou and Alimbou } \\
\text { forests and the special Manovo Gonda St Floris } \\
\text { park }\end{array}$ & & \\
\hline & & Promotion of tourism marketing & & \\
\hline & & $\begin{array}{l}\text { Construction of a convention center a cultural } \\
\text { tourism city }\end{array}$ & & \\
\hline
\end{tabular}




\section{Pillar 4. Develop Human Capital}

\begin{tabular}{|c|c|c|c|c|}
\hline Areas/sectors & Objectives/strategies & Priority activities programmed & Accomplishments during the first year & Comments \\
\hline \multirow[t]{11}{*}{ Education } & \multirow[t]{3}{*}{$\begin{array}{l}\text { Achievement of an } \\
\text { elementary school } \\
\text { enrollment rate of } \\
73 \text { percent for children 6- } \\
11 \text { years of age and reduce } \\
\text { the current gap between } \\
\text { girls and boys }\end{array}$} & $\begin{array}{l}\text { Rehabilitation/construction/equipment of } \\
\text { school infrastructures }\end{array}$ & $\begin{array}{l}\text { Rehabilitation and construction of schools in different } \\
\text { prefectures, including the refurbishment of three buildings } \\
\text { and construction of a school complex with six classrooms } \\
\text { and three offices in Vakaga } \\
\text { Equipment of four schools with 5,590 furnishings } \\
\text { including 5,200 bench-tables }\end{array}$ & \\
\hline & & $\begin{array}{l}\text { Provision of teaching materials for schools } \\
\text { and updating of the functional literacy } \\
\text { program }\end{array}$ & Purchase of 4,625 readers and 4,625 math textbooks & \\
\hline & & $\begin{array}{l}\text { Training of } 200 \text { parent teachers, } 2,300 \\
\text { teachers, and retraining of } 3,000 \text { teachers }\end{array}$ & $\begin{array}{l}\text { Accelerated training of } 450 \text { elementary } 1 \text { teachers } \\
\text { Contract recruitment of } 850 \text { teachers for elementary } 1 \\
\text { Organization of retraining sessions for civil service } \\
\text { teachers and parent teachers in the prefectures of Lobaye, } \\
\text { Nana Gribizi, Kémo, and Haute-Kotto }\end{array}$ & \\
\hline & \multirow{3}{*}{$\begin{array}{l}\text { Achievement of a primary } \\
\text { program completion rate } \\
\text { of } 74 \text { percent }\end{array}$} & $\begin{array}{l}\text { Rehabilitation/construction/equipment of } \\
\text { preschool centers }\end{array}$ & & \\
\hline & & $\begin{array}{l}\text { Extension of the informal education program } \\
\text { for children } 8-13 \text { years of age }\end{array}$ & & \\
\hline & & $\begin{array}{l}\text { Retraining and training of teachers and } \\
\text { administrative staff }\end{array}$ & & \\
\hline & \multirow{3}{*}{$\begin{array}{l}\text { Reduction of the dropout } \\
\text { rate to } 9 \text { percent for girls } \\
\text { and } 6 \text { percent for boys }\end{array}$} & Enhancement of the school environment & Construction of latrines and boreholes & \\
\hline & & Development of preschool activities & & \\
\hline & & $\begin{array}{l}\text { Construction and development of school } \\
\text { cafeterias }\end{array}$ & Opening of cafeterias in the schools & \\
\hline & \multirow{2}{*}{$\begin{array}{l}\text { Strengthening the } \\
\text { mobilization of players } \\
\text { and partners in the } \\
\text { education system }\end{array}$} & $\begin{array}{l}\text { Community and economic player awareness } \\
\text { and information on the importance of schools }\end{array}$ & & \\
\hline & & Capacity building for parents' organizations & $\begin{array}{l}\text { Training and monitoring of } 300 \text { members of parents' } \\
\text { organizations }\end{array}$ & \\
\hline
\end{tabular}




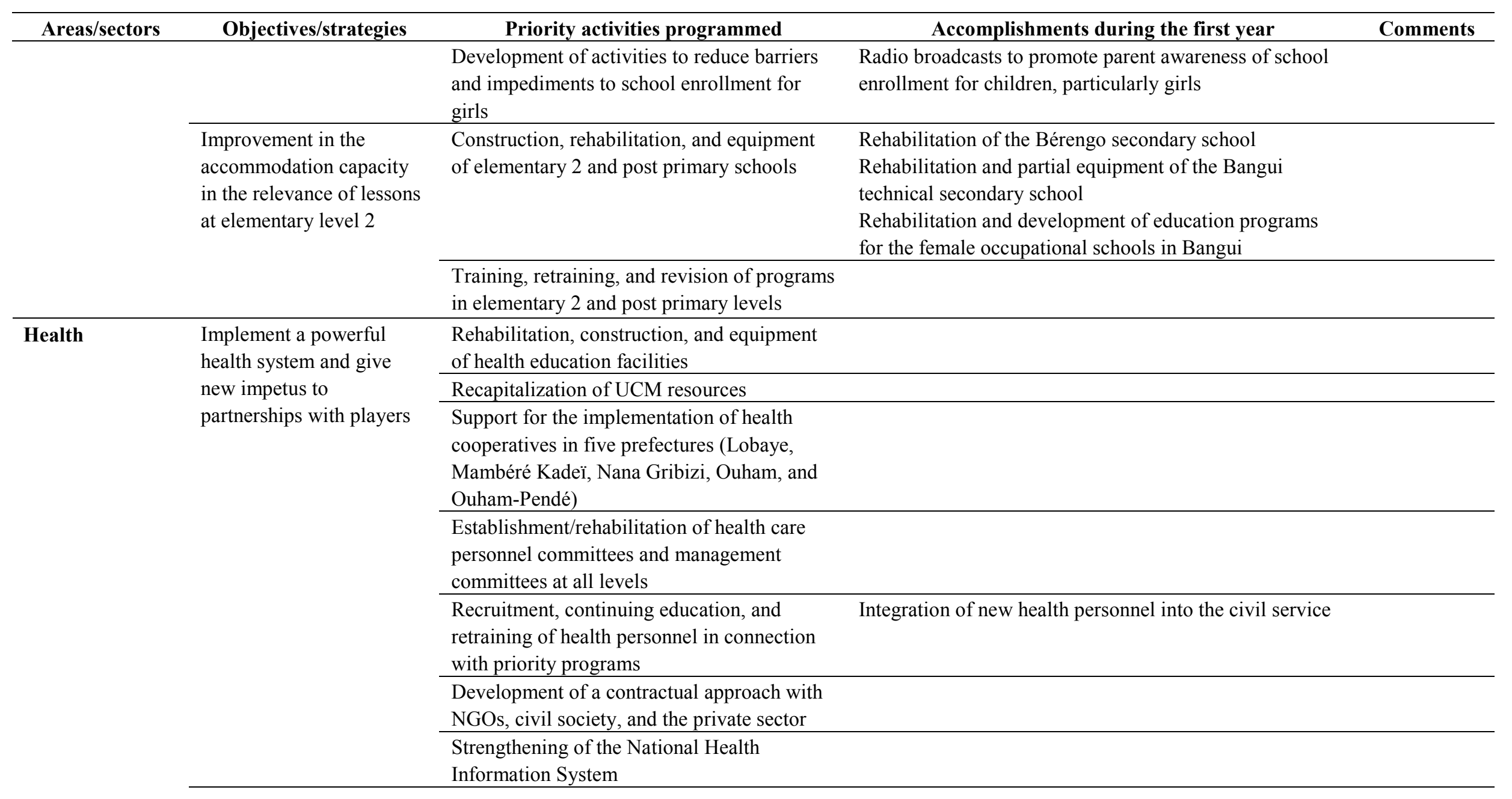




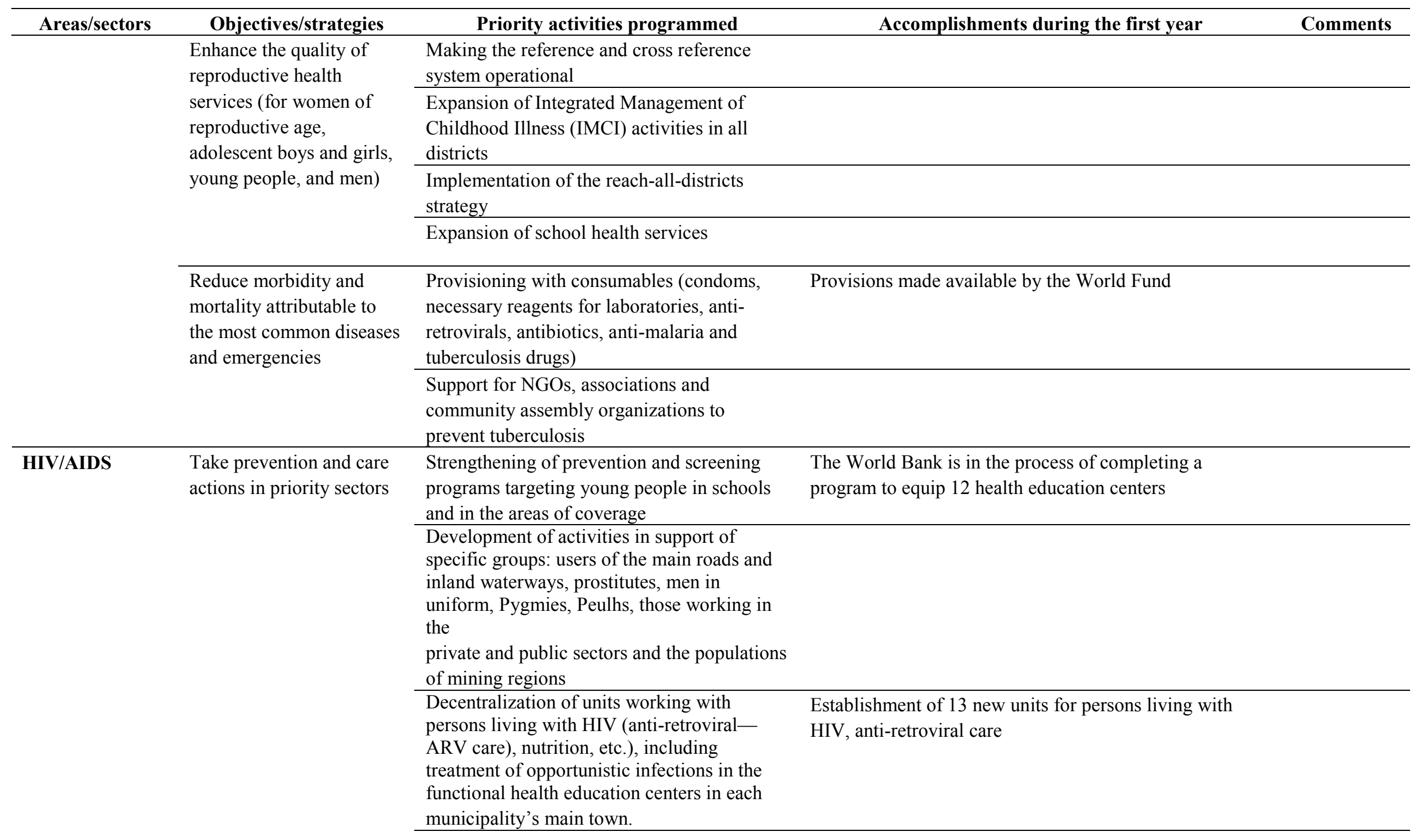




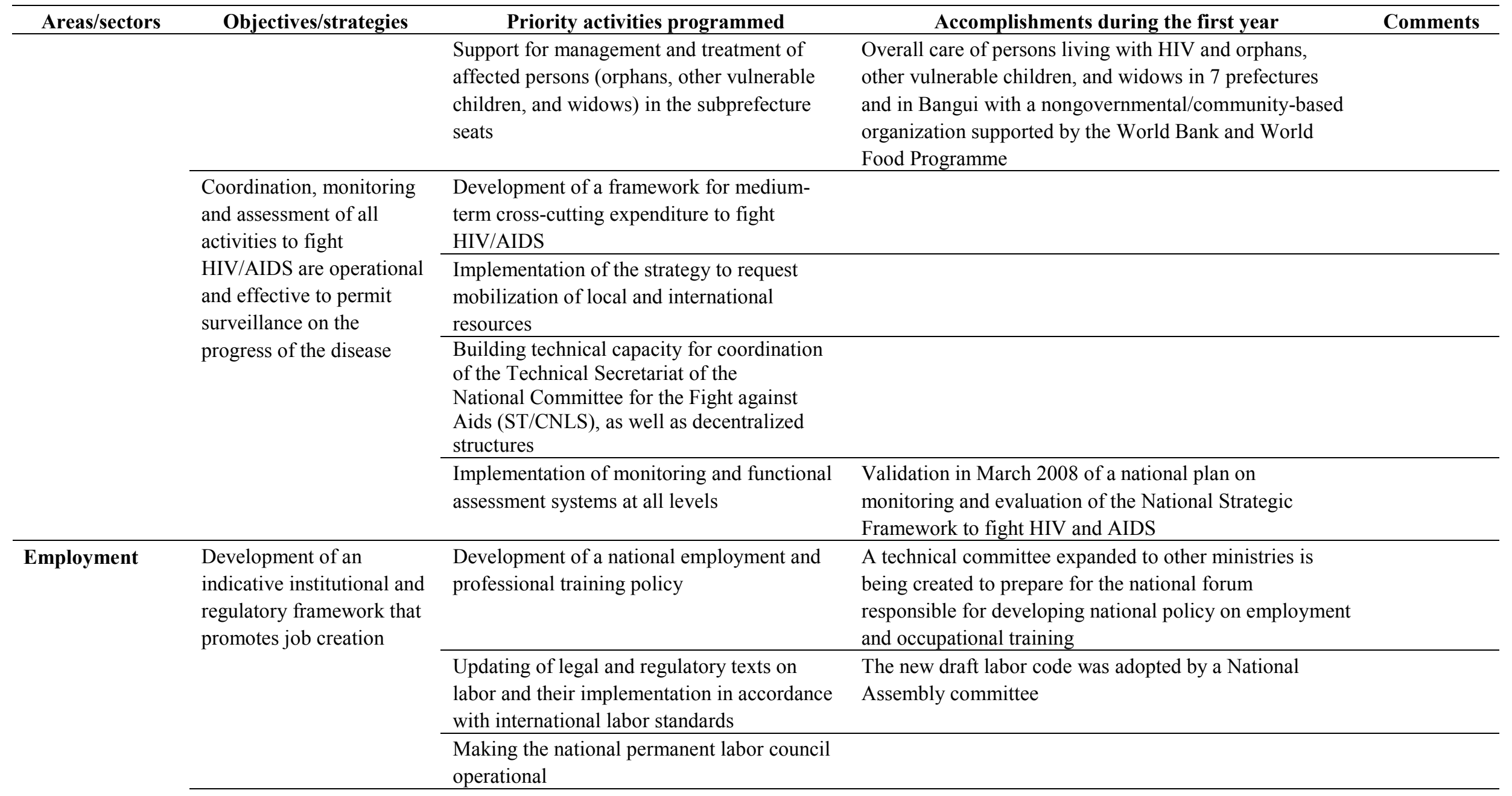




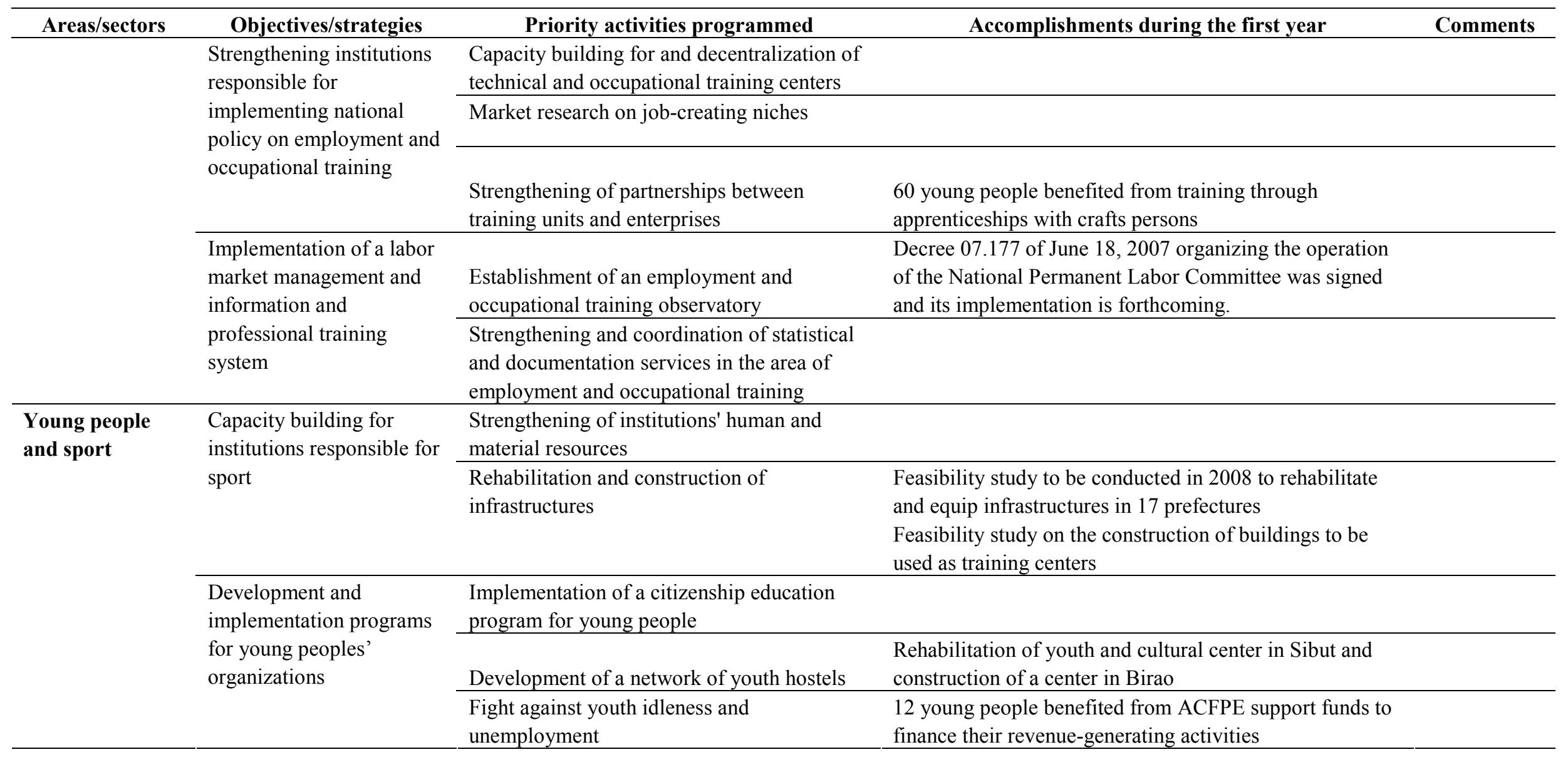

